$1-1-2018$

\title{
Qui Tam Litigation Against Government Officials: Constitutional Implications of a Neglected History
}

\section{Randy Beck}

Associate Dean for Academic Affairs \& Justice Thomas O. Marshall Chair of Constitutional Law University of Georgia School of Law, rbeck@uga.edu

University of Georgia School of Law

Research Paper Series

Paper No. 2017-06

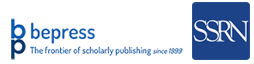

\section{Repository Citation}

Randy Beck, Qui Tam Litigation Against Government Officials: Constitutional Implications of a Neglected History, 93 Notre Dame L. Rev. 1235 (2018),

Available at: https://digitalcommons.law.uga.edu/fac_artchop/1172

This Article is brought to you for free and open access by the Faculty Scholarship at Digital Commons @ University of Georgia School of Law. It has been accepted for inclusion in Scholarly Works by an authorized administrator of Digital Commons @ University of Georgia School of Law. Please share how you have benefited from this access For more information, please contact tstriepe@uga.edu. 


\title{
QUI TAM LITIGATION AGAINST GOVERNMENT
}

\section{OFFICIALS: CONSTITUTIONAL IMPLICATIONS}

\author{
OF A NEGLEGTED HISTORY
}

\author{
Randy Beck*
}

The Supreme Court concluded twenty-five years ago, in Lujan v. Defenders of Wildlife, that uninjured private plaintiffs may not litigate "generalized grievances" about the legality of executive branch conduct. According to the Lujan Court, Congress lacked power to authorize suit by a plaintiff who could not establish some "particularized" injury from the challenged conduct. The Court believed litigation to require executive branch legal compliance, brought by an uninjured private party, is not a "case" or "controversy" within the Article III judicial power and impermissibly reassigns the President's Article II responsibility to "take Care that the Laws be faithfully executed." The decision effectively granted the President a semi-exclusive power to monitor and ensure the legality of a broad range of executive branch activity.

The Lujan Court overlooked a now relatively unfamiliar aspect of Anglo-American legal history. From the fourteenth through the eighteenth centuries, the English Parliament, American colonial and state legislatures, and early Federal Congresses routinely enacted "qui tam" legislation that authorized uninjured private "informers" to collect penalties for unlawful conduct by government officials. These qui tam statutes authorized private litigation against executive officials in circumstances that would be classified as generalized grievances under modern standing jurisprudence. The Lujan Court acknowledged historical use of qui tam legislation, but apparently believed such statutes were limited to regulation of private parties. The widespread practice of regulating government officials through qui tam legislation in the five centuries leading up to

(C) 2018 Randy Beck. Individuals and nonprofit institutions may reproduce and distribute copies of this Article in any format at or below cost, for educational purposes, so long as each copy identifies the author, provides a citation to the Notre Dame Law Review, and includes this provision in the copyright notice.

* Justice Thomas O. Marshall Chair of Constitutional Law, University of Georgia School of Law. The research for this Article was completed while I was a Garwood Visiting Fellow in Princeton University's James Madison Program in American Ideals and Institutions. I am grateful for the research opportunity provided by the James Madison Program and the University of Georgia School of Law. I also appreciate the helpful comments, questions, and support offered by Beth Beck, Evan Caminker, Elzbieta Cizewska-Martynska, Nathan Chapman, Eric Claeys, José Colen, Daniel DiSalvo, Gastón Espinosa, David Forte, Matthew Franck, Ben Johnson, Jon Kitch, Sarah Beth Kitch, Sarah Morgan Smith, Robert Nagel, Zachary Price, Jonathan Rose, Benjamin Storey, Jenna Storey, Sasha Volokh, Brad Wilson, participants in a faculty forum at the Southern Methodist University School of Law, and participants in a joint Emory-UGA Faculty Colloquium. The paper also benefited enormously from excellent research assistance and concept development discussions provided by Katie Croghan, Ashley Klein, Andrew McClintock, Stephen Morrison, Amanda Patterson, and Elizabeth Penland. 
the framing of our Constitution suggests the need to reconsider the reasoning of Lujan, though perhaps not the result, and to revise the Court's understanding of legislative tools available to monitor the legality of executive branch conduct.

INTRODUCTION ................................. 1237

I. The Constitution and Judicial Monitoring of Executive Conduct ............................ 1242

A. Recent Executive Conduct and the Rule of Law ......... 1243

B. Morrison v. Olson and the Unity of Executive Power ..... 1248

C. Lujan v. Defenders of Wildlife and Generalized Grievances ................................... 1249

D. Vermont Agency and Qui Tam Litigation of Generalized Grievances ..................................... 1253

II. Qui Tam Monitoring of Government Officials in

ENGLAND AND AMERICA ............................. 1259

A. British Qui Tam Statutes Regulating Government Officials . 1260

1. Enhanced Monitoring of Decentralized Government Activity ...................... 1262

2. Countering Official Resistance to Legislative Policies .................................. 1265

3. Bolstering Public Confidence in Governmental Processes ................................ 1266

B. Early State Qui Tam Statutes Regulating Public Officials... 1269 1. Monitoring Decentralized Government Activity ... 1269

a. Centralized Regulation of Local Administration ............................ 1269

b. Road Maintenance and Construction Obligations ........................... 1274

c. Qui Tam Regulation of Judicial Administration ....................... 1276

d. Qui Tam Monitoring of Inspection and Regulatory Regimes ................... 1280

e. Qui Tam Monitoring of Quasi-Public Functions ............................ 1284

2. Conflict of Interest Rules: Countering Incentives for Resistance ........................... 1285

3. Bolstering Public Confidence in Government ..... 1286

a. Elections .............................. 1286

b. Taxing and Spending ................... 1289

C. Early Federal Qui Tam Statutes Directed at Executive Branch Officials .................................. 1291

1. Revenue Officers.............................. 1291

2. Census Officials ........................... 1298

3. Treasury Officials ......................... 1300 
4. Postal Workers ........................ 1302

5. Federal Indian Agents................... 1304

III. Constitutional Implications of Qui Tam Regulation of Government Officials .......................... 1305

A. Qui Tam Litigation and Article III Standing .......... 1305

B. Qui Tam Litigation and the Take Care Clause.......... 1310

C. Qui Tam Litigation and the Unitary "Executive Power".... 1314

Conclusion ...................................... 1316

\section{INTRODUCTION}

The generation that framed our Constitution sought to establish "a government of laws, and not of men." 1 Government submission to law was central to the Framers' vision for a constitutionally limited republican government. $^{2}$ Over two centuries later, however, many commentators believe executive officials of both major political parties have subordinated the rule of law to the pursuit of other agendas. ${ }^{3}$ The past half century in particular has generated numerous reports of federal officials violating seem-

1 Marbury v. Madison, 5 U.S. (1 Cranch) 137, 163 (1803); Mass. Const. of 1780, pt. 1, art. XXX (separating legislative, executive, and judicial powers "to the end it may be a government of laws and not of men").

2 See John Adams, Thoughts on Government: Applicable to the Present State of the American Colonies, Universal Asylum and Columbian Mag., Dec. 1790, at 392 ("[T] he very defanition of a Republic, is 'an Empire of Laws, and not of Men.'”) (letter to the Hon. George Wythe, of Virginia).

3 See Frederick Schauer, The Political Risks (If Any) of Breaking the Law, 4 J. LEGAL ANALYsis 83, 90-93 (2012) (offering illustrative examples of asserted legal violations by federal officials and others, including military action in Libya, treatment of detainees, warrantless surveillance of citizens, and the Iran-Contra affair); Peter M. Shane, The Presidential Statutory Stretch and the Rule of Law, 87 U. Colo. L. Rev. 1231, 1237-48 (2016) (detailing and assessing "statutory stretches" employed to justify military operations in Kosovo, Iraq, Syria, and Libya as well as methods of interrogation and surveillance); Jack Goldsmith \& Matthew Waxman, Obama, Not Bush, Is the Master of Unilateral War, New RePublic (Oct. 14, 2014), https://newrepublic.com/article/119827/obamas-war-powers-legacy-he-must-seek-congres sional-authorization (critiquing Obama administration construction of War Powers Resolution in connection with Libya military operations); John O. McGinnis, The Coming Lawlessness: The Choices This Election Are Bad News for the Rule of Law, CrTy J. (Oct. 4, 2016), http:// www.city-journal.org/html/coming-lawlessness-14770.html (expressing concerns about legal fidelity of both major-party presidential candidates in the 2016 election). See generally David E. Bernstein, Lawless: The Obama Administration's Unprecedented Assault on the Constitution and the Rule of Law (2015) (detailing claims of unlawful Obama administration actions); David J. Barron \& Martin S. Lederman, The Commander in Chief at the Lowest Ebb-A Constitutional History, 121 HARv. L. Rev. 941, 1056-98 (2008) (surveying conflicts over legislative regulation of military and national security activities from the Truman administration through the George W. Bush administration); Ted Cruz, The Obama Administration's Unprecedented Lawlessness, 38 Harv. J.L. \& Pub. Pol'y 63 (2015) (also detailing claims of unlawful Obama administration actions). 
ingly clear legal requirements or offering implausible rationales for ignoring applicable rules. ${ }^{4}$

The importance of government respect for law warrants careful consideration of the mechanisms available for enforcing legal constraints on government officials, especially executive branch officials who apply the law to others. ${ }^{5}$ This Article will focus particular attention on the Supreme Court's twenty-five-year-old decision in Lujan v. Defenders of Wildlife, ${ }^{6}$ which articulated strict limits on judicial monitoring of executive action, even when authorized by Congress. The Lujan Court assigned the President a virtually exclusive authority to police the legality of a broad range of executive branch conduct. In litigation initiated by private parties, Lujan concluded, the judiciary may only evaluate the legality of executive action as a step toward redressing particularized harm to an identified plaintiff. ${ }^{7}$ The decision rested on two constitutional theories: challenges to the lawfulness of executive conduct by those without a particularized injury (1) would exceed Article III judicial power, which is limited to resolution of "Cases" and "Controversies," and (2) would reassign the President's Article II responsibility to "take Care that the Laws be faithfully executed," making courts "virtually continuing monitors" of executive action. ${ }^{8}$ Under Lujan, Congress lacks power to authorize private litigation of generalized grievances concerning the legality of executive branch conduct. ${ }^{9}$

This Article challenges Lujan's conclusion that only the President or his subordinates may litigate generalized grievances about executive lawlessness. The challenge rests on an often overlooked aspect of Anglo-American legal history, the extensive practice of regulating public officials through "qui tam" legislation. ${ }^{10}$ The qui tam label derives from a longer Latin phrase describing a litigant "who pursues [an] action on our Lord the King's behalf as well as his own." 11 From the fourteenth century through the eighteenth century, Parliament often enacted qui tam statutes that allowed any person to sue for a statutory offense and instructed the court to divide any recovery between the crown and the private litigant, called a "common informer." 12 The informer did not need to allege individualized injury "because every Offence, for which such Action is brought, is supposed to be a general Grievance to every Body." 13 The Supreme Court has acknowledged (post-Lujan) that qui tam actions satisfy Article III case or controversy requirements, given their

4 See infra notes 43-63 and accompanying text.

5 See 2 James Wilson, Of the Executive Department, in Lectures on Law 183, 198 (1790)

("[T] he law is higher than the magistrate, who administers it.").

6504 U.S. 555 (1992).

7 Id. at $560-61$.

8 Id. at 577 (quoting Allen v. Wright, 468 U.S. 737, 760 (1984))

9 Id. at 576-77.

10 See infra Part II.

11 Vt. Agency of Nat. Res. v. United States ex rel. Stevens, 529 U.S. 765, 768 n.1 (2000).

12 See infra Section II.A.

132 William Hawkins, A Treatise of the Pleas of the Crown 267 (1721). 
long historical pedigree, ${ }^{14}$ but continues to recite standing principles that cannot be reconciled with qui tam history. ${ }^{15}$ The Court has left open the question of whether qui tam statutes might violate the Article II Take Care Clause as interpreted in Lujan. ${ }^{16}$

The Lujan Court was aware of the historical use of qui tam legislation, but apparently believed informer statutes regulated only "private part[ies]."17 The Court overlooked Parliament's extensive use of qui tam legislation from the fourteenth century onward to enforce specified duties of government officials. ${ }^{18}$ This English practice of regulating public officials through qui tam legislation crossed the Atlantic and was widely followed in the American states at the time the Constitution was ratified. ${ }^{19}$ Federal legislators, beginning with the First Congress under the new Constitution, authorized qui tam litigation against numerous executive branch officials, including revenue officers, census workers, treasury employees, postal workers, and officials overseeing trade with Native American tribes. ${ }^{20}$ This centuries-old practice of authorizing qui tam informers to litigate generalized grievances concerning the lawfulness of government conduct undermines Lujan's conclusion that the Take Care Clause was intended to grant the President virtually exclusive authority to police the legality of executive action in the absence of particularized harm. ${ }^{21}$ It was well established at the time of the framing that a legislature could authorize judicial monitoring of executive conduct at the behest of private informers who lacked any individual injury.

Part I of this Article considers constitutional principles potentially relevant to judicial monitoring of executive branch legal compliance. In addition to the Article III case or controversy requirement and the Article II Take Care Clause argument from Lujan, we review the Supreme Court's decision in Morrison v. Olson, ${ }^{22}$ upholding appointment of "independent" prosecutors to investigate executive branch officials. The Morrison majority concluded that the President exercised "sufficient control" over the independent counsel to satisfy Article II, Section 1 of the Constitution, which vests all "executive power" in the President, ${ }^{23}$ while Justice Scalia's Morrison dissent argued that

14 See Vt. Agency, 529 U.S. at 771-78.

15 See infra note 136 and accompanying text.

16 See Vt. Agency, 529 U.S. at 778 n.8.

17 Lujan v. Defs. of Wildlife, 504 U.S. 555, 572-73 (1992) ("Nor . . is [this] the unusual case in which Congress has created a concrete private interest in the outcome of a suit against a private party for the Government's benefit, by providing a cash bounty for the victorious plaintiff." (emphasis added)).

18 See infra Section II.A.

19 See infra Section II.B.

20 See infra Section II.C.

21 See infra Section III.B.

22487 U.S. 654 (1988).

$23 I d$. at 696 ("Notwithstanding the fact that the counsel is to some degree "independent' and free from executive supervision to a greater extent than other federal prosecutors, in our view these features of the Act give the Executive Branch sufficient control over 
any limitation on the President's control made the statute unconstitutional. ${ }^{24}$ The "unitary executive" principle that underlay both the majority and dissenting opinions in Morrison provides another possible basis for objecting to litigation against executive officials by uninjured private citizens who are not subject to presidential control.

Part II of the Article focuses on the history of qui tam legislation directed at government officials in England, the early American states, and the initial Congresses following ratification of the Constitution. Qui tam legislation in England and the early American states helped accomplish several goals related to regulation of government conduct. Authorizing qui tam litigation (1) enhanced monitoring of decentralized government activity, ${ }^{25}$ (2) countered incentives for official resistance to legislative mandates, ${ }^{26}$ and (3) bolstered public confidence in the lawful performance of important government functions. ${ }^{27}$ These objectives help explain the decision by the First Congress to adopt qui tam statutes regulating federal revenue officers, ${ }^{28}$ census workers, ${ }^{29}$ and treasury officials, ${ }^{30}$ as well as the adoption of qui tam statutes in the Second Congress regulating postal employees ${ }^{31}$ and officials licensing trade with Native American tribes. ${ }^{32}$

Part III of the Article considers the constitutional issues raised above in light of the history surveyed in Part II. Section III.A addresses the "case or controversy" requirement and the doctrine of standing. Cass Sunstein argues that the history of qui tam legislation shows that the Court reached the wrong outcome in Lujan. ${ }^{33}$ On this view, Congress has power to create universal standing to litigate generalized grievances, whether or not the statute includes a bounty. While that could be an accurate understanding of Article III, the conclusion does not necessarily follow from the history of qui tam legislation. The bounty provision of a qui tam statute gives the successful informer an individual right to payment, a concrete individual interest that distinguishes a qui tam statute from a bare universal authorization to sue. The Endangered Species Act (ESA) citizen suit provision considered in Lujan is also distinguishable from a traditional qui tam statute in terms of the duties enforced and the relief available. Qui tam statutes tended to define specific legal duties of executive officials that could be enforced through private collection of financial penalties, while the ESA sought to authorize

the independent counsel to ensure that the President is able to perform his constitutionally assigned duties.").

24 Id. at 705 (Scalia, J., dissenting).

25 See infra subsections II.A.1, II.B.1.

26 See infra subsections II.A.2, II.B.2.

27 See infra subsections II.A.3, II.B.3.

28 See infra subsection II.C.1.

29 See infra subsection II.C.2.

30 See infra subsection II.C.3.

31 See infra subsection II.C.4.

32 See infra subsection II.C.5.

33 Cass R. Sunstein, What's Standing After Lujan? Of Citizen Suits, "Injuries," and Article III, 91 Mich. L. Rev. 163, 164 (1992). 
injunctive relief to enforce any provision of a complex and partially indeterminate regulatory scheme. The history of qui tam legislation should, however, change the way we think about standing and the role of the courts in cases presenting generalized grievances. The Lujan Court overreached when it described "particularized" injury as part of the "irreducible constitutional minimum" of Article III standing, and when it suggested that Congress may never authorize private litigation of generalized grievances about executive branch conduct. ${ }^{34}$

Section III.B considers implications of Part II's history for Lujan's reading of the Take Care Clause. The Anglo-American history of regulating government officials through qui tam litigation provides powerful evidence that Article II was not understood to create a semi-exclusive presidential authority to police the legality of executive branch conduct. Based on more than four and a half centuries of legislative practice, the First Congress believed it could grant members of the public standing to litigate generalized grievances about the legality of executive branch conduct, at least when it conferred a financial interest in the litigation. So far as we know, neither President Washington nor anyone else raised any constitutional concerns.

Lujan's reading of the Take Care Clause not only overlooks settled patterns of interbranch relations at the time of the framing, but also ignores the practical obstacles that would have made any centralized presidential monitoring of federal officials largely superficial. ${ }^{35}$ The Constitution anticipated activities that would take federal officers throughout the already vast territory of the United States at a time when means of travel and communication were much less advanced than today. Viewed from the perspective of the late eighteenth century, a semi-exclusive presidential power to monitor the lawfulness of executive conduct would have meant virtually no monitoring at all for a great deal of important executive branch activity.

Section III.C considers whether qui tam litigation against executive branch officers can be reconciled with the "unitary executive" principle embodied in Article II, Section 1, which vests all "executive power" in the President. The best answer to this constitutional concern flows from Blackstone's explanation that qui tam legislation authorizes a species of "popular action," because the statutory right to sue is "given to the people in general." 36 The power to file a qui tam action is a nongovernmental power and hence does not implicate the tripartite constitutional allocation of governmental power among the three branches.

A number of eighteenth-century mechanisms called on citizens to participate in the enforcement of laws and the projection of communal force. Local sheriffs could call out a posse comitatus of armed citizens to help catch a fleeing criminal or keep the peace. Citizen jurors were called upon to authorize prosecutions as members of a grand jury, or to render verdicts about the legality of a defendant's conduct as members of a petit jury. The

34 Lujan v. Defs. of Wildlife, 504 U.S. 555, 560 (1992).

35 See infra notes 508-12 and accompanying text.

363 William Blackstone, Commentaries * 160. 
government could muster the citizen militia to fight external enemies or to enforce the laws. Seagoing vessels could be licensed as "privateers," supplementing government naval forces. All of these mechanisms empowered citizens to participate in law enforcement and extend the government's coercive reach, while often serving as checks on governmental power. Qui tam regulation of government officials can be seen as another of these institutions through which the public participated in law enforcement in order to both supplement and restrain executive authority.

The purpose of this Article is to highlight an underappreciated aspect of our legal history that has significant implications for ongoing constitutional debates. I do not advocate broad revival of the tradition of regulating executive officials through qui tam legislation. Elsewhere, I consider whether selective use might be appropriate to promote legal accountability in particular contexts, such as where a conflict of interest within the executive branch could hinder enforcement of the laws. ${ }^{37}$ Whatever implications this aspect of our history might have for future policy discussions, however, this Article looks to the past principally to inform present debates about constitutional power.

\section{The Constitution and Judicial Monitoring of Executive Conduct}

James Wilson, one of our first Supreme Court Justices, lectured on law at what became the University of Pennsylvania. ${ }^{38}$ In a lecture on the executive department, Wilson expressed the view, widely embraced in the framing generation, that the "principle of democracy" means the law should be "higher than the magistrate, who administers it." 99 Many of the core political values of the framing generation could be realized only if government officials respected legal constraints on their conduct. Popular sovereignty would be operationalized through law, as agents of the people functioned within constitutional boundaries established by popular conventions and legislative boundaries enacted by the people's representatives. ${ }^{40}$ Liberty would be pre-

37 See Randy Beck, Promoting Executive Accountability Through Qui Tam Legislation, 21 Chap. L. Rev. (forthcoming 2018). For example, perhaps it would be useful to enact a qui tam statute penalizing an official who expends federal funds without a supporting congressional appropriation, an area where presidential support for the expenditure could preclude internal executive branch remedies and standing doctrine would complicate efforts to obtain a judicial remedy. Id.; see also U.S. Const. art. I, §9 ("No Money shall be drawn from the Treasury, but in Consequence of Appropriations made by Law . . ..").

38 See James Wilson (1742-1798), Penn Biographies, http://www.archives.upenn.edu/ people/1700s/wilson_jas.html (last visited Nov. 28, 2017). Wilson also signed the Declaration of Independence and participated in the Constitutional Convention. Id.

39 See 2 Wilson, supra note 5, at 198.

40 See The Federalist No. 78, at 452 (Alexander Hamilton) (ABA 2009) ("[T] he power of the people is superior to" the legislature and judiciary, which are bound by "[the will of] the people, declared in the Constitution.”); John Locke, The SEcond Treatise on Civil Government, ch. XI, § 141, at 79 (Prometheus Books 1986) (1690) (“[N] or can [the people] be bound by any laws but such as are enacted by those whom they have chosen and authorised to make laws for them."); 2 WILson, supra note 5, at 198 ("[T] he principle 
served through law that defined and limited the power of government. ${ }^{41}$ Law would even secure a measure of equality, helping ensure that those seen as similarly situated would be treated in similar ways. ${ }^{42}$

Given the central role of government submission to law in realizing our political values, we should pay careful attention to whether executive officials observe legal constraints on their conduct and to available mechanisms for enforcing compliance. In this Part, I review claims that executive officials sometimes ignore clear legal rules or offer dubious justifications for executive action. We then consider principles drawn from Articles II and III of the Constitution that may limit judicial examination of executive conduct. The constitutional analysis begins with a brief consideration of Morrison $v$. Olson, an important Article II case, and then pays particular attention to Lujan $v$. Defenders of Wildlife, which embraced both Article II and Article III grounds for limiting litigation against executive officials. This Part of the Article concludes with an introduction to qui tam legislation, a feature of Anglo-American legal history that casts considerable doubt on the historical analysis driving the Lujan decision.

\section{A. Recent Executive Conduct and the Rule of Law}

While our political philosophy prioritizes executive respect for legal boundaries, the past half century has generated numerous reports of illegal conduct by the executive branch, or conduct of dubious legality. The Nixon administration declined to spend appropriated funds on policy grounds unrelated to the authorizing statutes ${ }^{43}$ and covered up a burglary of Demo-

of democracy [means] . . . that the law is higher than the magistrate, who administers it; that the constitution is higher than both; and that the supreme power, remaining with the people, is higher than all the three.”).

41 See John Courtney Murray, S.J., We Hold These Truths: Catholic Reflections on the American Proposition 32 (1960) (noting that under early American political philosophy, "[government's] authority derived from law" and "[b]y the same token its authority was limited by law"); 3 Joseph Story, Commentaries on the Constitution of the United States $\$ 1608$, at 472 (1833) (arguing that a republic with a limited constitution cannot have "any practical restraint upon the acts of the government, or any practical enforcement of the rights of the citizens" without an independent judiciary "to interpret the constitution and laws, and to preserve the citizens against oppression and usurpation"); 1 James Wilson, Of the Study of the Law in the United States, in Lectures on Law, supra note 5, at 431, 435 ("Without liberty, law loses its nature and its name, and becomes oppression. Without law, liberty also loses its nature and its name, and becomes licentiousness.").

42 William Cranch, Preface to 1 Cranch iii (1804) ("[A judge] can not decide a similar case differently, without strong reasons, which, for his own justification, he will wish to make public."); 1 James WiLson, Of Man, as a Member of Society, in Lectures on LAW, supra note 5, at 621, 638 ("With regard to all, there is an equality in rights and in obligations; there is that 'jus aequum,' that equal law, in which the Romans placed true freedom.”); Thomas Jefferson, First Inaugural Address (Mar. 4, 1801) ("[T] he minority possess their equal rights, which equal law must protect, and to violate would be oppression.”).

43 See Train v. City of New York, 420 U.S. 35, 41 (1975) (EPA lacked authority to refuse allocation of funds authorized for municipal sewage and sewage treatment facilities); St. Highway Comm'n of Mo. v. Volpe, 479 F.2d 1099, 1118 (8th Cir. 1973) (U.S. Secretary of 
cratic National Committee headquarters that eventually led to the President's resignation. ${ }^{44}$ The Ford administration sent troops into Cambodia to rescue the crew of a captured merchant ship (the Mayaguez), going so far as to bomb an airfield and storage depot after the rescue, notwithstanding congressional funding restrictions forbidding "combat activities" and "hostilities" in Southeast Asia. ${ }^{45}$ A State Department official acknowledged that the Carter administration sometimes violated section 502B of the Foreign Assistance Act ${ }^{46}$ banning security assistance to countries engaged in a pattern of human rights violations. ${ }^{47}$ National security officials in the Reagan administration violated at least the spirit and probably the letter of the Boland Amendment by funneling profits from Iranian arms sales to the Nicaraguan Contras. ${ }^{48}$ George H.W. Bush and other presidents have been criticized for ignoring statutory language based on signing statements asserting broad and untested claims of executive power. ${ }^{49}$ The Clinton administration construed an appropriations provision as authorizing participation in NATO's Kosovo operation beyond the sixty-day limit of the War Powers Resolution (WPR), even though the WPR explicitly rejects authorization by that means. ${ }^{50}$

Transportation did not have express or implied authority to withhold highway funds on nonstatutory grounds); cf. Brown v. Ruckelshaus, 364 F. Supp. 258, 263 (C.D. Cal. 1973) (denying standing to challenge EPA's withholding of funds for water treatment plants).

44 See Gerald Caplan, The Making of the Attorney General: John Mitchell and the Crimes of Watergate Reconsidered, 41 McGeorge L. Rev. 311, 326-32 (2010) (reviewing James Rosen, The Strong Man (2008)).

45 Barron \& Lederman, supra note 3, at 1072.

46 See Stephen B. Cohen, Conditioning U.S. Security Assistance on Human Rights Practices, 76 Ам. J. INT'L L. 246, 263-75 (1982) (discussing interpretation of various statutory terms and application to various aid packages; noting situation involving Argentina when nonstatutory exceptions "were abused in a way that seriously undermined the purpose of section 502B" and proposed military training package to Guatemala that "seemed to be clearly contrary to section 502B"); see also Jeffrey B. Whalen, Does the Law of Human Rights GuideOr Rationalize-U.S. Foreign Policy?, 79 Am. Soc'y InT'L L. Proc. 18, 19 (1985) ("The executive branch has found it very difficult to comply with the laws and usually has sought to circumvent, ignore or even violate the laws. Both the Reagan and Carter Administrations have been unable or unwilling to carry out fully the requirements of the statutes.").

47 See 22 U.S.C. \$ 2304 (2012).

48 See Schauer, supra note 3, at 95 ("Someone asking the question, ex ante, whether the Iran-Contra scheme violated the Boland Amendment could not have been in any serious doubt about the answer to that question."). But see Cruz, supra note 3, at 92 ("It is disputed whether the diversion of the Iran arms sales proceeds to the Contras violated the Boland Amendment.").

49 See Peter M. Shane, Presidential Signing Statements and the Rule of Law as an "Unstructured Institution," 16 WM. \& MARY BILL RTS. J. 231, 242-43 (2007) (signing statements by first President Bush included "some of the more expansive claims of presidentialist constitutionalism"; second President Bush issued signing statements raising constitutional objections to over 1000 statutory provisions "frequently based on no legal authority whatever"); see also Shane, supra note 3, at 1260-61 (noting second President Bush raised constitutional objections to "1,070 provisions embodied in 127 statutes" including some that "were wholly unprecedented and even silly").

50 See Barron \& Lederman, supra note 3, at 1090 \& n.619. 
The proliferation of terrorist incidents and political polarization since the turn of the century have, if anything, heightened pressures on the executive branch to overstep legal boundaries. The Department of Justice under President George W. Bush offered a narrow reading of the "severe physical or mental pain or suffering" required for interrogation to constitute "torture," based on a strained analogy to use of the phrase "severe pain" in an unrelated medical benefits statute. ${ }^{51}$ Only the threat of resignation by several high level Justice Department officials prevented continuation of an ongoing surveillance program viewed as legally indefensible. ${ }^{52}$ The Obama administration violated the WPR by ordering extensive Libya operations based on an implausible argument that U.S. forces were not engaged in "hostilities." 53 Published reports indicate that the Foreign Intelligence Surveillance Court issued a top secret ruling criticizing the National Security Agency for prohibited data searches raising serious Fourth Amendment issues and for a lack of candor in disclosing the extent of the practice. ${ }^{54}$ Critics also alleged a number of unlawful acts in implementing the Affordable Care Act (ACA), including delay of the employer mandate beyond the statutory effective date ${ }^{55}$ and

51 See Shane, supra note 3, at 1238, 1269-72; Memorandum from Jay S. Bybee, Assistant Attorney Gen., U.S. Dep't of Justice, to Alberto R. Gonzales, Counsel to the President 5-6 (Aug. 1, 2002) (regarding standards of conduct for interrogation under 18 U.S.C. $\S \S 2340-2340 \mathrm{~A}$, and defining "severe physical or mental pain or suffering" in torture statute by reference to potential sources of "severe pain" in statute concerning medical benefits).

52 See Julian Sanchez, What the Ashcroft "Hospital Showdown" on NSA Spying Was All About, Ars TechnicA (July 29, 2013), https://arstechnica.com/tech-policy/2013/07/what-theashcroft-hospital-showdown-on-nsa-spying-was-all-about/.

53 Goldsmith \& Waxman, supra note 3 (saying the Obama administration rendered WPR's sixty-day limit "meaningless in many important contexts" with "unconvincing" argument that the administration was "not engaged in 'hostilities' even though they were part of seven months of air strikes that helped decimate Libyan army units and bring down the government"); Shane, supra note 3, at 1246-48; Jennifer Steinhauer, Obama Adviser Defends Libya Policy to Senate, N.Y. Times (June 28, 2011), http://www.nytimes.com/2011/06/29/ us/politics/29powers.html (quoting Democratic Senator Jim Webb on the administration's position: "When you have an operation that goes on for months, costs billions of dollars, where the United States is providing two-thirds of the troops . . . where they're dropping bombs that are killing people, where you're paying your troops offshore combat pay and there are areas of prospective escalation . . . I would say that's hostilities.").

54 See Tim Johnson, Secret Court Rebukes NSA for 5-Year Illegal Surveillance of U.S. Citizens, Miami Herald (May 26, 2017), http://www.miamiherald.com/news/nation-world/ national/article152948259.html.

55 Under section $1513(\mathrm{~d})$ of the ACA, the employer mandate provisions were to apply “to months beginning after December 31, 2013." Pub. L. No. 111-148, tit. I, § 1513(d), 124 Stat. 119, 256 (2010). The administration nevertheless decided that employers with fifty to ninety-nine employees would not be expected to comply with the provision until 2016, a delay of two years, and that employers with a hundred or more employees would not need to comply until 2015. See Juliet Eilperin \& Amy Goldstein, White House Delays Health Insurance Mandate for Medium-Size Employers Until 2016, WAsh. Post (Feb. 10, 2014), https:// www.washingtonpost.com/national/health-science/white-house-delays-health-insurancemandate-for-medium-sized-employers-until-2016/2014/02/10/ade6b344-9279-11e3-84e1- 
federal payments to health insurance companies in violation of statutory directives ${ }^{56}$ or in the absence of congressional appropriations. ${ }^{57}$ The Trump administration was accused of unconstitutional conduct, or at least stretching prior legal precedents, in bombing Syria without first seeking congressional authorization. ${ }^{58}$ High-level officials of both major parties have conducted public business using private email systems, skirting laws designed to promote transparency, preserve records, and increase cybersecurity. ${ }^{59}$ Administrative agencies routinely fail to satisfy regulatory deadlines set by statute. ${ }^{60}$

27626c5ef5fb_story.html; Avik Roy, Opinion, Well, Never Mind Then: To Ease the Transition to a 30-Hour Week,' Obamacare Employer Mandate Delayed Again, Forbes (Feb. 10, 2014), http:/ /www.forbes.com/sites/theapothecary/2014/02/10/well-never-mind-then-to-ease-thetransition-to-a-30-hour-week-obamacare-employer-mandate-delayed-again/\#6ec7aadb57fe.

56 Section 1341 of the ACA provided for the Department of Health and Human Services (HHS) to collect funds from insurers for a reinsurance program, administrative costs of the reinsurance program, and additional amounts to deposit into the U.S. Treasury. The statute provided that the funds collected for the third purpose "shall be deposited into the general fund of the Treasury of the United States and may not be used for the [reinsurance] program established under this section.” Pub. L. No. 111-148, tit. I, § 1341(b) (4), 124 Stat. 119, 208-11 (2010). Nevertheless, HHS allocated all of the funds collected to the reinsurance program, rather than depositing funds into the Treasury as required by the statute. U.S. Gov't Accountability Office, GAO-B-328016, Department of Health and Human Services: Transitional Reinsurance Program (2016); see Seth Chandler, Opinion, Busted: GAO Finds Payments to Insurers Under Affordable Care Act Are Illegal, Forbes (Sept. 29, 2016), http://www.forbes.com/sites/theapothecary/2016/09/29/busted-gao-findspayments-to-insurers-under-affordable-care-act-are-illegal/\#6828d20147db.

57 See U.S. House of Representatives v. Burwell, 185 F. Supp. 3d 165, 168 (D.D.C. 2016) (determining that HHS payments to insurers pursuant to section 1402 of ACA violate Constitution's Appropriations Clause).

58 See Jack Goldsmith, Opinion, The Constitutionality of the Syria Strike Through the Eyes of OLC (and the Obama Administration), LAwFARE (Apr. 7, 2017, 7:31 AM), https://www.lawfare blog.com/constitutionality-syria-strike-through-eyes-olc-and-obama-administration;

Michael Stokes Paulsen, Opinion, Trump's First Unconstitutional War, NaT'L Rev. (Apr. 11, 2017), http://www.nationalreview.com/article/446633/donald-trump-syria-strike-unconsti tutional-declaration-war. But see John Yoo, Opinion, Trump's Syria Strike Was Constitutional, NAT'L Rev. (Apr. 13, 2017), http://www.nationalreview.com/article/446692/trump-syria strike-constitutional-presidents-have-broad-war-powers.

59 See U.S. Office of Inspector General, ESP-16-03, Office of the Secretary: Evaluation of Email Records Management and Cybersecurity Requirements (2016) (reporting on varying use of nondepartmental email accounts for State Department business by officials in multiple administrations); see also Matt Apuzzo \& Maggie Haberman, At Least 6 White House Advisers Used Private Email Accounts, N.Y. TIMEs (Sept. 25, 2017), https:// www.nytimes.com/2017/09/25/us/politics/private-email-trump-kushner-bannon.html.

60 See generally Biodiversity Legal Found. v. Badgley, 309 F.3d 1166, 1169-71 (9th Cir. 2002) (multiple Fish and Wildlife Service failures to satisfy twelve-month deadline for addressing listing petitions under Endangered Species Act); In re Bluewater Network, 234 F.3d 1305 (D.C. Cir. 2000) (Coast Guard failure to issue oil spill regulations eight years after statutory deadline); Forest Guardians v. Babbitt, 174 F.3d 1178 (10th Cir. 1999) (Fish and Wildlife Service failed to meet one-year deadline for identifying critical habitat for Rio Grande silvery minnow); In re Barr Labs., Inc., 930 F. $2 d 72$ (D.C. Cir. 1991) (FDA failed to act within 180-day deadline for decisions on new drug and antibiotic applications); Oxfam Am., Inc. v. SEC, 126 F. Supp. 3d 168 (D. Mass. 2015) (failure to meet 270-day deadline for 
We could debate at length the legality of some of these executive actions, the constitutionality of the duties imposed, and the wisdom of the underlying legislative directives. ${ }^{61}$ But we could also cite other examples of legally dubious executive behavior. ${ }^{62}$ Commentators from varying political and jurisprudential perspectives have discerned threats to the rule of law in such executive conduct. ${ }^{63}$ My own view is that human nature poses a perpetual threat to the rule of law. Humans chafe at impediments to the pursuit of passionately desired ends, including government officials convinced of the justice, necessity, or expediency of a favored course of action. James Madison observed that "power is of an encroaching nature" and must "be effectually restrained from passing the limits assigned to it." 64 The "great difficulty" in framing a government, he argued, lies in "enabl[ing] the government to control the governed" while "oblig[ing] it to control itself." 65 Preserving the rule of law requires a mutually reinforcing combination of cultural habits and accessible legal remedies. ${ }^{66}$ The need for an effective response to unlawful conduct warrants close examination of constitutional principles that may limit the power of courts to review the legality of executive action.

issuance of regulations under Dodd-Frank); Ctr. for Food Safety v. Hamburg, No. C124529, 2013 WL 5718339 (N.D. Cal. 2013) (FDA failed to meet seven deadlines for food safety regulations).

61 I have argued elsewhere that the President's duty to obey the law and the presidential oath to uphold the Constitution justify ignoring statutes that he reasonably views as unconstitutional. See J. Randy Beck, Presidential Defiance of "Unconstitutional" Laws: Reviving the Royal Prerogative, 16 Const. Comm. 419 (1999) (book review).

62 See sources discussing numerous additional examples of legally questionable conduct by various administrations, supra note 3 .

63 See Bernstein, supra note 3, at 4 ("The Obama administration's actions . . reflect long-standing progressive unease with the concept of the rule of law.”); McGinnis, supra note 3 (arguing that both major party presidential candidates in the 2016 election would be unreliable defenders of the rule of law); Shane, supra note 49, at 231, 233 ("Critics of the Bush 43 administration have not infrequently charged that the administration's unilateralism is antagonistic to the rule of law."); Shane, supra note 3, at 1272 (explaining that stretching a statute to reach a surprising interpretation "is more consistent with rule of law values" than advancing a claim of uncontrollable and unreviewable presidential power, but for several reasons "the statutory stretch strategy might be thought actually to undermine the rule of law").

64 The Federalist No. 48, at 279 (James Madison) (ABA 2009).

65 The Federalist No. 51, at 294 (James Madison) (ABA 2009).

66 Peter Shane points out that "many plausible conceptions" of the "rule of law" can be offered. See Peter M. Shane, Chevron Deference, the Rule of Law, and Presidential Influence in the Administrative State, 83 Fordham L. Rev. 679, 680 (2014). However, one suspects that most of the contending alternatives would include an expectation that "government actors should obey the law" and that "meaningful recourse should be available" when law has been violated. $I d$. at 681 . Shane focuses on recourse for those "injured" by violations of law. Id. But I contend that maintaining respect for the rule of law also requires effective remedies for unlawful conduct even when one cannot identify an injured party with sufficient motivation to pursue relief. 


\section{B. Morrison v. Olson and the Unity of Executive Power}

The Supreme Court in Morrison v. Olson considered constitutional challenges to the independent counsel provisions of the Ethics in Government Act, a post-Watergate statute designed to deal with potential conflicts of interest that can arise when the Department of Justice investigates important presidential appointees. ${ }^{67}$ The statute instructed the Attorney General to seek judicial appointment of an independent counsel to investigate high-ranking executive branch officials unless the Attorney General's preliminary inquiry found "no reasonable grounds to believe that further investigation is warranted." 68 One argument against the statute was that it violated the separation of powers by limiting the President's control of an official wielding Article II executive power. ${ }^{69}$

The Morrison majority acknowledged that "the functions performed by the independent counsel are 'executive' in the sense that they are law enforcement functions that typically have been undertaken by officials within the Executive Branch." 70 The Court rejected the separation of powers argument, however, because the statute gave the President various means to control the independent counsel. The Act permitted the Attorney General to remove the independent counsel for "good cause," a power that allowed the President to carry out his constitutional duty to take care that "the laws are 'faithfully executed.'"71 While the "no reasonable grounds" for further investigation standard might seem to require frequent appointment of an independent counsel, the Court noted that the Attorney General's decision whether to seek appointment was subject to the Attorney General's unreviewable discretion. ${ }^{72}$ The appointing court defined the independent counsel's jurisdiction by reference to facts submitted by the Attorney General, and the independent counsel was required to follow Justice Department policy if "possible." 73 The Court concluded that these features of the statute afforded the executive branch "sufficient control over the independent counsel to ensure that the President is able to perform his constitutionally assigned duties." 74

The Court's opinion in Morrison was written by Chief Justice Rehnquist, who had previously served as Assistant Attorney General for the Office of Legal Counsel (OLC), a division of the Department of Justice that deals regularly with separation of powers issues. ${ }^{75}$ The dissenting opinion was written

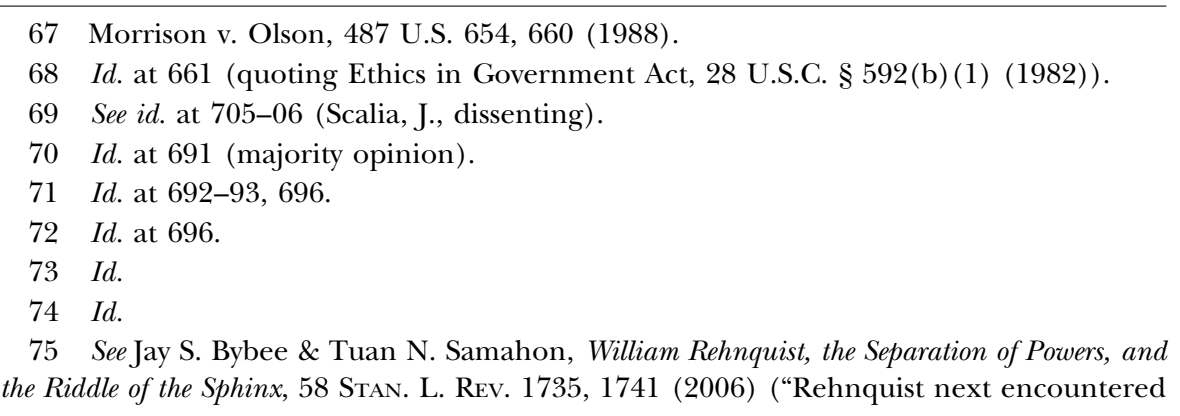


by Justice Scalia, another former head of OLC. ${ }^{76}$ Justice Scalia argued that the statute violated the Constitution by depriving the President of plenary authority over the independent counsel. Focusing on Article II, Section 1's grant of "the executive Power" to the President, Justice Scalia argued that "this does not mean some of the executive power, but all of the executive power." 77 The Framers of the Constitution deliberately rejected models of divided executive power. Alexander Hamilton defended this aspect of the constitutional design, arguing that unity in the Executive promoted energetic law enforcement and helped maintain accountability. ${ }^{78}$ Based on the Framers' decision to vest executive power in a single set of hands, Justice Scalia believed the Constitution would not tolerate any statutory limitation that deprived the President of exclusive control over the exercise of executive power. ${ }^{79}$

While the majority and Justice Scalia disagreed over the degree of control the President must exercise, they agreed on the basic principle that executive power must be subject to presidential direction. If Congress provided for a person to exercise "executive power" within the meaning of Article II, Section 1, without giving sufficient means of presidential supervision, the statute would presumably be unconstitutional under either the majority or dissenting opinions. All of the Justices in Morrison viewed the independent counsel's authority to investigate and prosecute criminal charges against executive branch officials as an exercise of executive power. This constitutional bar to the completely independent exercise of executive power could affect who may litigate against executive officials and under what circumstances.

\section{Lujan v. Defenders of Wildlife and Generalized Grievances}

A few years after Morrison, the Supreme Court issued its decision in Lujan v. Defenders of Wildlife, ${ }^{80}$ an important precedent on the law of standing. The doctrine of standing seeks to identify the sorts of "Cases" and "Controversies" that fall within the Article III judicial power. ${ }^{81}$ Lujan was brought by environmental organizations against the Secretary of the Interior, challenging regulations that applied the Endangered Species Act (ESA) only to federal government actions in this country or on the high seas. ${ }^{82}$ The central question for the Court was whether the plaintiffs had standing to seek judi-

the separation of powers with his appointment as Assistant Attorney General for the Office of Legal Counsel (OLC) in the Justice Department.").

76 Nelson Lund, Rational Choice at the Office of Legal Counsel, 15 CArdozo L. Rev. 437, 500 n.150 (1993).

77 Morrison, 487 U.S. at 705 (Scalia, J., dissenting).

78 The Federalist No. 70 (Alexander Hamilton).

79 Morrison, 487 U.S. at 708 (Scalia, J., dissenting) ("As I have said, however, it is ultimately irrelevant how much the statute reduces Presidential control.”).

80 See 504 U.S. 555, 555 (1992).

81 See U.S. Const. art. III, § 2.

82 Under section 7(a) (2) of the Endangered Species Act: 
cial review of the federal government's failure to apply the ESA to federal projects in foreign countries. The Court described "the core component of standing" as "an essential and unchanging part of the case-or-controversy requirement of Article III." ${ }^{83}$ It laid out an oft-cited version of a familiar three-part test:

Over the years, our cases have established that the irreducible constitutional minimum of standing contains three elements. First, the plaintiff must have suffered an "injury in fact" - an invasion of a legally protected interest which is (a) concrete and particularized, and (b) "actual or imminent, not 'conjectural' or "hypothetical." " Second, there must be a causal connection between the injury and the conduct complained of-the injury has to be "fairly ... trace[able] to the challenged action of the defendant, and not ... th [e] result [of] the independent action of some third party not before the court." Third, it must be "likely," as opposed to merely "speculative," that the injury will be "redressed by a favorable decision." 84

In cases challenging the legality of government conduct, the majority indicated, a person who is "an object" of the government's action will ordinarily have standing, but standing will be harder to demonstrate when the "plaintiff's asserted injury arises from the government's allegedly unlawful regulation (or lack of regulation) of someone else." 85 The Lujan majority concluded that the plaintiff environmental organizations could not show that the government's restricted application of the ESA would cause an "imminent" injury to their members, because the individual members had no definitive plans to travel to countries where endangered animals were allegedly threatened by federal action. ${ }^{86}$

The most relevant portion of the Lujan opinion for our purposes is the section rejecting the "procedural injury" theory of standing embraced by the Court of Appeals. The appellate court had relied on the ESA's "citizen suit" provision, which authorized "any person" to "commence a civil suit on his own behalf" to enjoin violation of "any provision" of the ESA, including the provision requiring interagency consultation before federal actions that

Each Federal agency shall, in consultation with and with the assistance of the Secretary [of the Interior], insure that any action authorized, funded, or carried out by such agency . . . is not likely to jeopardize the continued existence of any endangered species or threatened species or result in the destruction or adverse modification of habitat of such species which is determined by the Secretary, after consultation as appropriate with affected States, to be critical.

Lujan, 504 U.S. at 558 (alteration in original) (quoting 16 U.S.C. § 1536(a) (2) (1982)) . The initial regulation applied the ESA to federal actions abroad, but a revised regulation reinterpreted the Act to apply only to actions taken within the United States and on the high seas. Id. at 558-59.

$83 I d$. at 560.

$84 I d$. at 560-61 (footnote omitted) (citations omitted).

$85 I d$. at 561-62.

$86 I d$. at 563-64. 
might threaten the habitat of endangered animals. ${ }^{87}$ As explained by the Lujan majority, the Court of Appeals reasoned:

$[\mathrm{T}]$ he citizen-suit provision creates a "procedural righ [t]" to consultation in all "persons"-so that anyone can file suit in federal court to challenge the Secretary's (or presumably any other official's) failure to follow the assertedly correct consultative procedure, notwithstanding his or her inability to allege any discrete injury flowing from that failure. ${ }^{88}$

The Lujan majority rejected the appellate court's procedural injury theory based on caselaw holding that

a plaintiff raising only a generally available grievance about governmentclaiming only harm to his and every citizen's interest in proper application of the Constitution and laws, and seeking relief that no more directly and tangibly benefits him than it does the public at large-does not state an Article III case or controversy. 89

The majority surveyed a number of cases in which the Court had applied this rule against private litigation of "generalized grievances." 90 For instance, in Schlesinger v. Reservists Committee to Stop the War, the Court dismissed a suit by citizens claiming that members of Congress violated the Constitution's Incompatibility Clause by holding commissions in the military reserves. ${ }^{91}$ The Court noted that the conduct challenged "would adversely affect only the generalized interest of all citizens in constitutional governance," a kind of interest that could not serve as a predicate for standing to sue. ${ }^{92}$ The Court has similarly held that an injury a person suffers in her capacity as a taxpayer, in common with all other taxpayers, is too generalized to support Article III standing. ${ }^{93}$ Consistent with this long line of cases, the Lujan Court insisted that federal court litigation must be premised on a "particularized" injury, meaning "that the injury must affect the plaintiff in a personal and individual way."94

Lujan broke new ground when it expressly ruled that the Constitution prevents Congress from conferring standing on private persons to litigate generalized grievances:

$[\mathrm{T}]$ here is absolutely no basis for making the Article III inquiry turn on the source of the asserted right. Whether the courts were to act on their own, or at the invitation of Congress, in ignoring the concrete injury requirement described in our cases, they would be discarding a principle fundamental to the separate and distinct constitutional role of the Third Branch-one of

87 Id. at 571-72 (quoting 16 U.S.C. $\$ 1540(\mathrm{~g})(1982)$ ).

$88 I d$. at 572 (second alteration in original) (quoting Defs. of Wildlife v. Lujan, 911

F.2d 117, 121-22 (8th Cir. 1990)).

89 Id. at $573-74$.

$90 \quad$ Id. at $574-75$.

91 See Schlesinger v. Reservists Comm. to Stop the War, 418 U.S. 208 (1974).

$92 I d$. at $217,220$.

93 Lujan, 504 U.S. at 574-75.

94 Id. at 560 n.1. 
the essential elements that identifies those "Cases" and "Controversies" that are the business of the courts rather than of the political branches. ${ }^{95}$

The Court's analysis rested on its understanding of the role of courts, as distinguished from the role of the political branches of government: "The province of the court,' as Chief Justice Marshall said in Marbury v. Madison, 'is, solely, to decide on the rights of individuals.' Vindicating the public interest (including the public interest in Government observance of the Constitution and laws) is the function of Congress and the Chief Executive."96 Since vindicating the public interest is the job of the political branches, the Constitution would not allow Congress to transfer that function to the courts by conferring standing to litigate generalized grievances on private parties:

To permit Congress to convert the undifferentiated public interest in executive officers' compliance with the law into an "individual right" vindicable in the courts is to permit Congress to transfer from the President to the courts the Chief Executive's most important constitutional duty, to "take Care that the Laws be faithfully executed." It would enable the courts, with the permission of Congress, "to assume a position of authority over the governmental acts of another and co-equal department," and to become "virtually continuing monitors of the wisdom and soundness of Executive action."97

In short, the Lujan Court thought congressional attempts to confer standing absent a particularized injury would infringe the Constitution in two distinct ways: (1) by exceeding Article III's case-or-controversy limitation on judicial power, and (2) by undermining the President's responsibility to ensure faithful execution of the laws under the Take Care Clause of Article II. ${ }^{98}$

The Lujan Court grounded its decision on what it took to be the traditional relationship between the judicial and executive branches. The Court has elsewhere said that the case-or-controversy limitation is designed to identify suits "traditionally amenable to" 99 or "historically viewed as capable of resolution through the judicial process." ${ }^{00}$ The Lujan majority, noting that

$95 \quad I d$. at 576.

$96 I d$. (citation omitted).

$97 I d$. at 577 (citations omitted) (first quoting U.S. Const. art. II, § 3; then quoting Massachusetts v. Mellon, 262 U.S. 447, 489 (1923); and then quoting Allen v. Wright, 468 U.S. 737, 760 (1984)).

98 Lujan's standing principles apply to any federal court litigation-not just suits against the government-but it is likely that the "generalized grievance" limitation will have heightened impact on lawsuits challenging unlawful government conduct, a context in which individuals might be motivated to challenge illegal conduct that does not affect them individually. The Article II limitation would seem to apply principally to suits against executive branch officials, but it is possible that a court could view some lawsuits against private parties as implicating the President's Take Care Clause responsibilities.

99 Steel Co. v. Citizens for a Better Env't, 523 U.S. 83, 102 (1998).

100 GTE Sylvania, Inc. v. Consumers Union of the U.S., Inc., 445 U.S. 375, 382 (1980) (quoting Flast v. Cohen, 392 U.S. 83, 95 (1968)); see also Sprint Commc'ns Co. v. APCC Servs., Inc., 554 U.S. 269, 274 (2008) ("We have often said that history and tradition offer a meaningful guide to the types of cases that Article III empowers federal courts to consider."). 
the Constitution does not define "legislative Powers," "executive Power," or "judicial Power," argued that "the Constitution's central mechanism of separation of powers depends largely upon common understanding of what activities are appropriate to legislatures, to executives, and to courts."101 In seeking this "common understanding" of the appropriate activities of the judiciary, the Court relied on eighteenth- and early nineteenth-century sources-the Federalist Papers and Marbury v. Madison. ${ }^{102}$ Justice Scalia was more explicit about the historical nature of the inquiry in a law review article that anticipated the Lujan ruling, referring to a separation of powers-based requirement of particularized injury as the "original understanding" of standing doctrine. ${ }^{103}$

The central elements of Lujan's standing analysis continue to guide the Court a quarter century later. For instance, two terms ago, in Spokeo, Inc. v. Robins, the Court decided that the Ninth Circuit conducted an incomplete Article III analysis when it focused on allegations that the defendant had posted inaccurate information in violation of the plaintiff's rights under the Fair Credit Reporting Act. ${ }^{104}$ This was enough to satisfy Lujan's requirement of particularization, since it was the plaintiff's rights (rather than public rights) that were allegedly violated, but did not necessarily satisfy Lujan's distinct requirement that the plaintiff's injury be "concrete."105 The Court quoted Lujan's description of injury in fact as part of the "irreducible constitutional minimum' of standing" 106 and reiterated the principle that Article III does not allow Congress to confer standing on an uninjured litigant. ${ }^{107}$

\section{Vermont Agency and Qui Tam Litigation of Generalized Grievances}

Lujan's restrictions on private litigation of generalized grievances were based on the Court's understanding of the judiciary's traditional role. The

101 Lujan, 504 U.S. at 559-60 (internal quotation marks omitted) (first quoting U.S. Const. art. I, $\S 1$; then quoting U.S. Const. art. II, $\S 1$; and then quoting U.S. Const. art. III, $§ 1)$.

102 See id. at 560 (discussing The Federalist No. 48 (James Madison)); id. at 576-77 (discussing Marbury v. Madison, 5 U.S. (1 Cranch) 137 (1803)).

103 Antonin Scalia, The Doctrine of Standing as an Essential Element of the Separation of Powers, 17 SufFolK U. L. Rev. 881, 897-98 (1983).

104 Spokeo, Inc. v. Robins, 136 S. Ct. 1540, 1545-46 (2016).

$105 I d$. at 1548 ("Particularization is necessary to establish injury in fact, but it is not sufficient. An injury in fact must also be 'concrete.' Under the Ninth Circuit's analysis, however, that independent requirement was elided.").

106 Id. at 1547 (quoting Lujan, 504 U.S. at 560).

$107 I d$. at 1547-48 ("Injury in fact is a constitutional requirement, and "[i]t is settled that Congress cannot erase Article III's standing requirements by statutorily granting the right to sue to a plaintiff who would not otherwise have standing.'" (alteration in original) (quoting Raines v. Byrd, 521 U.S. 811, 820 n.3 (1997))); id. at 1549 ("Congress' role in identifying and elevating intangible harms does not mean that a plaintiff automatically satisfies the injury-in-fact requirement whenever a statute grants a person a statutory right and purports to authorize that person to sue to vindicate that right. Article III standing requires a concrete injury even in the context of a statutory violation."). 
ruling embraced a familiar view of the legal universe. Courts exist to provide redress for private litigants injured by unlawful conduct. They are also available to redress legal claims on behalf of the public, but those claims are pursued by public officials elected or appointed for that purpose. Private litigants seek judicial redress for particularized harms to private interests and public officials seek judicial redress for generalized harms to public interests. This view of the legal system is logical and orderly. It leaves litigation on behalf of the public in the hands of professionals, chosen by voters or accountable to elected officials. It allows government litigators to pursue the optimal level of law enforcement through discretion in case selection, avoiding cases that might result in overdeterrence of socially beneficial conduct. ${ }^{108}$ It reduces opportunities for private litigants to subvert the public good in pursuit of private interests. ${ }^{109}$

But while the Lujan Court's understanding of the judicial role was logical, orderly, and in certain respects appealing, it was also based on an inaccurate view of eighteenth-century Anglo-American legal history. English and early American courts did entertain suits by "aggrieved" private parties seeking redress for particularized injuries, and they did entertain suits by public officials seeking redress for unlawful conduct that harmed the public. But eighteenth-century English and American courts also routinely entertained suits by private litigants who suffered no particularized injury and who sought judicial redress based on generalized grievances about unlawful activity. From the fourteenth through the eighteenth centuries, qui tam litigation by uninjured common informers was one of three extremely common methods of statutory enforcement, alongside suits by public officials and suits by injured parties. ${ }^{110}$

Beginning in the fourteenth century, the English Parliament enacted hundreds of qui tam statutes, most of which followed familiar patterns. Blackstone explains qui tam legislation as follows:

$[\mathrm{M}]$ ore usually, these forfeitures created by statute are given at large, to any common informer; or, in other words, to any such person or persons as will sue for the same: and hence such actions are called popular actions, because they are given to the people in general. Sometimes one part is given to the king, to the poor, or to some public use, and the other part to the informer or prosecutor; and then the suit is called a qui tam action, because it is brought by a person "qui tam pro domino rege, $\mathcal{E}$ c, quam pro seipso in hac parte sequitur." If the king therefore himself commences this suit, he shall have

108 See J. Randy Beck, The False Claims Act and the English Eradication of Qui Tam Legislation, 78 N.C. L. Rev. 539, 620 (2000) ("In deciding whether to bring suit, the public prosecutor can engage in a case-by-case consideration of the regulatory benefits and the social costs of a particular enforcement action.").

109 Id. at 615-37 (detailing situations in which qui tam informers might pursue personal interests in ways that undermine the public interest).

$110 I d$. at 565-608 (describing the English history of qui tam enforcement); see Jonathan Rose, Maintenance in Medieval England 297 \& n.152 (2017) (discussing qui tam enforcement of livery statutes in which plaintiffs sued for half a statutory penalty and did not allege personal harm or seek compensatory damages). 
the whole forfeiture. But if any one hath begun a qui tam, or popular, action, no other person can pursue it; and the verdict passed upon the defendant in the first suit is a bar to all others, and conclusive even to the king himself. ${ }^{111}$

A typical example of qui tam legislation is found in a 1745 English statute designed to prevent merchants from passing off foreign linens as British or Irish linens to obtain export bounties. ${ }^{112}$ Parliament required the marking of domestic linens and imposed forfeitures for inaccurate markings. ${ }^{113}$ Under one section of the statute, any person who engaged in specified forms of mislabeling was subject to the following penalty:

[S] uch Person or Persons shall forfeit the Sum of five Pounds for every Piece of Linen so stamped as aforesaid, to be sued for and recovered by Bill, Plaint, or Information, in any of His Majesty's Courts of Record at Westminster, the Court of Session, Court of Judiciary, or Court of Exchequer in Scotland, or in any of his Majesty's Courts of Record in Dublin . . . ; and one Moiety of the said Penalties shall be to the Use of the King's Majesty, His Heirs, and Successors, and the other Moiety to such Person or Persons as will sue or prosecute for the same. ${ }^{114}$

In authorizing litigation by any person who would sue, the statute vastly expanded law enforcement resources and greatly increased the likelihood that a merchant fraudulently marking foreign linen would be caught, all at no cost to the government apart from the contingent promise of half of any penalties recovered. ${ }^{115}$ While the provision for the informer's "moiety" might occasionally siphon off money that could have been recovered by public officials, the statute's overall effect on the treasury was likely a net positive due to disclosure of statutory violations that would otherwise remain secret. Since export bounties were paid by the government, private plaintiffs authorized to enforce the 1745 statute would be seeking redress for generalized grievances rather than particularized injuries.

William Hawkins's eighteenth-century treatise on Pleas of the Crown discussed qui tam litigation in its chapter on proceedings by information. ${ }^{116}$

1113 Blackstone, supra note 36 , at *160; see also $i d$. at *262 (explaining that statutory forfeitures "which regard mere matters of police and public convenience" are "usually left to be inforced by common informers, in the qui tam informations or actions, of which we have formerly spoken").

112 An Act for Effectually Preventing the Exportation of Foreign Linens, Under the Denomination of British or Irish Linens 1745, 18 Geo. 2 c. 24, Preamble (Eng.).

113 See id. $\$ \S 2-4$.

$114 I d . \S 3$.

115 See, e.g., Beck, supra note 108, at 560 (in debate over the qui tam provisions of the False Claims Act, Senator Langer argued that informers would give the Justice Department additional help in enforcing the statute).

1162 Hawkins, supra note 13, at 277-80. Qui tam statutes might allow enforcement through either criminal or civil process, or give the informer a choice. See 4 William Blackstone, Commentaries *303 ("Informations . . . which are partly at the suit of the king, and partly at that of a subject . . . are usually brought upon penal statutes, which inflict a penalty upon conviction of the offender, one part to the use of the king, and another to the use of the informer; and are a sort of qui tam actions, (the nature of which 
Hawkins noted that an information could be "merely at the Suit of the King" or "partly the Suit of the King, and partly the Suit of the Party," with the latter "commonly called an Information qui tam."117 Statutes were deemed subject to qui tam enforcement if they gave part of a penalty to any private litigant:

I take it for granted, that [an information or action qui tam] lie on no Statute which prohibits a Thing as being an immediate Offence against the Publick good in general, under a certain Penalty, unless the Whole, or Part of such Penalty be expressly given to him who will sue for it; because otherwise it goes to the King, and nothing can be demanded by the Party. But where such Statute gives any Part of such Penalty to him who will sue for it by Action or Information, \&c. I take it to be settled at this Day, That any one may bring such Action, or Information, and lay his Demand tam pro Domino Rege quam pro seipso. ${ }^{118}$

Penal statutes sometimes regulated conduct harming both the public and private individuals, and an injured party could file a qui tam action as a means of obtaining redress. ${ }^{119}$

While injured parties could bring qui tam actions, Hawkins makes clear that the judiciary did not impose on qui tam informers any particularized injury requirement of the sort found in Lujan. Hawkins noted judicial authority holding " $[\mathrm{t}]$ hat a Popular Action may conclude ad grave damnum ['to the great damage'], without adding of the Plaintiff; because every Offence, for which such Action is brought, is supposed to be a general Grievance to every Body." 120 Thus, while Lujan concluded that plaintiffs could not bring suit if they suffered only a generalized grievance, Hawkins viewed the generalized nature of a grievance as a justification for conferring standing on a private litigant. Hawkins later indicated that common informers were not entitled to recover costs under a statute "which gives the Demandant his Costs in all Cases wherein he shall recover his Damages; for this seems to suppose some Damage to have been done to the Demandant in particular, which cannot be said in any popular Action."121 Again, the notion of damage "to the Demandant in particular" is just another phrasing of Lujan's "particularized" injury requirement. Hawkins's analysis shows that no particularized injury was expected when an informer pursued a "popular" or qui tam action. Parliament was well aware of the difference between injured parties and common informers, and sometimes authorized common informers to sue only if the aggrieved party did not. ${ }^{122}$

was explained in a former volume) only carried on by a criminal instead of a civil process." (footnote omitted)).

1172 Hawkins, supra note 13, at 259, 264.

$118 I d$. at 265.

$119 I d$. (noting that some penal statutes concerned conduct causing "an immediate Damage to the Party" but also affecting the public good; under such statutes, the "general Opinion" held that "the Party grieved may, and it is holden by some that he ought" to bring his suit as a qui tam action (footnote omitted)).

$120 I d$. at 267.

121 Id. at 273.

122 See id. at 272. 
The Supreme Court in Lujan understood that our legal history included qui tam legislation, but may not have appreciated the ubiquity of such legislation at the time the Constitution was adopted. The majority made clear that the ESA's citizen suit provision did not constitute qui tam legislation: "Nor, finally, is [this] the unusual case in which Congress has created a concrete private interest in the outcome of a suit against a private party for the Government's benefit, by providing a cash bounty for the victorious plaintiff." 123 The reference to qui tam legislation as "unusual" was accurate as of the date of Lujan, but failed to acknowledge that such legislation was widely used in the eighteenth century, shaping the Framers' understanding of the role of courts and the meaning of the Article III terms "case" and "controversy." Moreover, Lujan's description of qui tam legislation as allowing suit "against a private party" 124 implies that the Court was unaware of the widespread use of qui tam statutes to regulate government officials, a point demonstrated in Part II below.

The Court was confronted with the extensive history of qui tam legislation eight years after Lujan in Vermont Agency of Natural Resources $v$. United States ex rel. Stevens. ${ }^{125}$ The Vermont Agency case was brought under the most important remaining federal qui tam statute, the Civil War-era False Claims Act, which permits private litigants to sue for frauds against the government. ${ }^{126}$ The case presented the question of whether the False Claims Act could be used against a state agency that received money from the federal government. On its own initiative, the Court requested briefing on the jurisdictional issue of whether a qui tam statute satisfies the requirements of Article III standing. ${ }^{127}$

On the standing issue, the Vermont Agency opinion highlighted the injury in fact requirement from the Court's prior jurisprudence and noted that the qui tam relator was seeking to litigate based on an injury suffered by the United States, rather than an injury to the "complaining party." ${ }^{28}$ The Court nevertheless approved qui tam standing on two grounds. First, the Court drew an analogy to litigation by the assignee of a claim:

We believe ... that adequate basis for the relator's suit for his bounty is to be found in the doctrine that the assignee of a claim has standing to assert the

123 Lujan v. Defs. of Wildlife, 504 U.S. 555, 572-73 (1992).

$124 I d$. at 573 .

125529 U.S. 765 (2000).

126 See 31 U.S.C. $\$ \$ 3729-3733$ (2012).

127 See Vt. Agency of Nat. Res. v. United States ex rel. Stevens, 528 U.S. 1015, 1015 (1999) (mem.) (directing parties to file supplemental briefs on the question: "Does a private person have standing under Article III to litigate claims of fraud upon the government?").

128 Vermont Agency, 529 U.S. at 771 ("Art. III judicial power exists only to redress or otherwise to protect against injury to the complaining party." (quoting Warth v. Seldin, 422 U.S. 490, 499 (1975)) (internal quotation marks omitted)). 
injury in fact suffered by the assignor. The FCA can reasonably be regarded as effecting a partial assignment of the Government's damages claim. ${ }^{129}$

Second, the Court pointed to the long history of qui tam legislation as support for its decision: "We are confirmed in this conclusion by the long tradition of qui tam actions in England and the American Colonies. That history is particularly relevant to the constitutional standing inquiry . . .."130 The Court observed that "[q]ui tam actions appear to have been as prevalent in America as in England, at least in the period immediately before and after the framing of the Constitution." 131 The Court also documented enactment of a number of qui tam statutes by the First Congress following ratification of the Constitution. ${ }^{132}$ The Vermont Agency Court thought this history "well nigh conclusive with respect to the question before us here: whether qui tam actions were 'cases and controversies of the sort traditionally amenable to, and resolved by, the judicial process." "133

The Vermont Agency Court tacitly recognized that its holding was inconsistent with the recitation of standing doctrine in Lujan. In Vermont Agency's description of the "irreducible constitutional minimum" of standing, Justice Scalia omitted the requirement that the injury be "particularized" and spoke about the injury as something the plaintiff must "demonstrate" rather than something the plaintiff must "have suffered."134 However, the Court expressly reserved the question of "whether qui tam suits violate Article II, in

$129 I d$. at 773. Vermont Agency's suggestion that qui tam legislation effects a partial assignment of the government's claim may work as a modern analogy, but it seems anachronistic as a justification for qui tam standing. Claim assignment was generally impermissible in England during the centuries when qui tam legislation developed. See Sprint Commc'ns Co. v. APCC Servs., Inc., 554 U.S. 269, 275 (2008) ("Prior to the 17th century . . . , with only limited exceptions, English courts refused to recognize assignments at all.").

130 Vermont Agency, 529 U.S. at 774. On the historical nature of the Article III inquiry, the Court highlighted an opinion by Justice Frankfurter arguing that, under the Constitution, "[j] udicial power could come into play only in matters that were the traditional concern of the courts at Westminster and only if they arose in ways that to the expert feel of lawyers constituted 'Cases' or 'Controversies." Id. (alteration in original) (quoting Coleman v. Miller, 307 U.S. 433, 460 (1939) (Frankfurter, J., concurring)).

131 Id. at 776.

132 Id. at 777 \& nn.6-7.

133 Id. at 777 (quoting Steel Co. v. Citizens for a Better Env't, 523 U.S. 83, 102 (1998)). While the Vermont Agency Court found standing to litigate a qui tam suit, it concluded on the merits that the False Claims Act provision allowing suit against a "person" did not authorize suit against a state or state agency. Id. at 787.

134 Compare Lujan v. Defs. of Wildlife, 504 U.S. 555, 560 (1992) (“[I]rreducible constitutional minimum" of standing requires that the "plaintiff must have suffered an injury in fact' - an invasion of a legally protected interest which is (a) concrete and particularized, and (b) 'actual or imminent, not "conjectural" or "hypothetical"" (quoting Whitmore v. Arkansas, 495 U.S. 149, 155 (1990))), with Vermont Agency, 529 U.S. at 771 ("[I]rreducible constitutional minimum" of standing requires that the plaintiff "must demonstrate "injury in fact' - a harm that is both 'concrete' and 'actual or imminent, not conjectural or hypothetical'” (quoting Whitmore, 495 U.S. at 155)). 
particular the Appointments Clause of $\S 2$ and the 'take Care' Clause of $\S 3$. ." 135 Later decisions of the Court have reverted to Lujan's formulation that the plaintiff must "suffer" a "particularized" injury to satisfy the "irreducible constitutional minimum" of standing. ${ }^{136}$ Thus, while Vermont Agency offered a partial and temporary corrective to the Court's Article III standing jurisprudence, the Court has thus far ignored any broader implications of qui tam history for understanding interbranch relations under Articles II and III.

\section{Qui Tam Monitoring of Government Officials in England AND AMERICA}

The Lujan Court concluded that uninjured private litigants may not sue to remedy generalized grievances about unlawful executive conduct, even if authorized to do so by Congress. The Court believed such litigation did not present a "case" traditionally considered appropriate for judicial resolution and that it would undermine the President's Article II responsibility to supervise execution of the laws. While the Court knew of the tradition of qui tam legislation, it considered such statutes "unusual" and believed they were confined to regulation of private parties. The Court was unaware that at the time the Constitution was ratified, Anglo-American legislatures routinely authorized qui tam suits by uninjured private informers to litigate generalized grievances about unlawful government conduct, including conduct of executive officials. This practice was widely followed in England from the fourteenth century onward, was common in all thirteen American colonies/states in the eighteenth century, and was embraced in a number of statutes enacted by the first two Congresses. ${ }^{137}$

135 Vermont Agency, 529 U.S. at 778 n.8; see also id. at 801-02 (Stevens, J., dissenting).

136 See Spokeo, Inc. v. Robins, 136 S. Ct. 1540, 1547-48 (2016); Lexmark Int'l, Inc. v. Static Control Components, Inc., 134 S. Ct. 1377, 1386 (2014); see also Sprint Commc'ns Co. v. APCC Servs., Inc., 554 U.S. 269, 273-74 (2008); Massachusetts v. EPA, 549 U.S. 497, 517 (2007).

137 Earlier studies of qui tam legislation have noted the existence of qui tam provisions directed at public officials. See, e.g., Evan Caminker, The Constitutionality of Qui Tam Actions, 99 YAle L.J. 341, 342 n.3 (1989) (listing early federal qui tam statutes, including a statute directed at marshals participating in the census); Harold J. Krent, Executive Control over Criminal Law Enforcement: Some Lessons from History, 38 Aм. U. L. Rev. 275, 303 (1989) (" $[\mathrm{B}]$ y authorizing a qui tam action, Congress could permit private citizens to sue the government officials to collect penalties incurred because of misfeasance in office.”); Sunstein, supra note 33, at 175 ("Notably, the informers' action was available against both private defendants and public officials.”); Steven L. Winter, The Metaphor of Standing and the Problem of Self-Governance, 40 STAN. L. REv. 1371, 1407 (1988) ("These statutes provided a common mechanism to regulate, by judicial sanction, governmental officials where there was likely to be no aggrieved party with a private cause of action.”). This Article seeks to document that qui tam regulation of government officials had been routinely employed for hundreds of years in England and America by the time the Constitution was ratified, and was naturally embraced by early Congresses as an extension of longstanding legislative practice. 


\section{A. British Qui Tam Statutes Regulating Government Officials}

In the twelfth year of King Edward II, Parliament adopted a number of statutory provisions designed to address problems in the English legal system. ${ }^{138}$ One provision related to enforcement of "assizes" that regulated the price, measure, and quality of consumer goods. ${ }^{139}$ Records of manorial courts show numerous fines assessed when appointed "ale-tasters" accused local brewers of "breaking" the "assize of beer," for example, by using too small of a gallon measure or otherwise departing from regulatory standards. ${ }^{140}$ The 1318 statute applied to any "Officer in City or in Borough" responsible for enforcing "Assises of Wines and Victuals." ${ }^{141}$ If such officers engaged in wholesale or retail marketing of goods regulated by the assizes, the merchandise would be forfeited to the King. ${ }^{142}$ The statute was presumably designed to eliminate conflicts of interest affecting officials with enforcement obligations. ${ }^{143}$ Allowing a market participant to regulate a competitive marketplace could undermine evenhanded enforcement of the law and cause other merchants to distrust the regulatory process.

The challenge for Parliament lay in ensuring that local officials observed the restriction on their commercial conduct, notwithstanding the economic incentive to violate the statute. England included forty distinct counties covering more than 50,000 square miles. ${ }^{144}$ The statute would apply to officers in dozens of cities and boroughs. ${ }^{145}$ Given the highly decentralized nature

138 Statute of York 1318, 12 Edw. 2 Preamble (Eng.).

139 See Sir Frederick Pollock \& Frederic William Maitland, 1 The History of English Law Before the Time of Edward I 612 (2d ed. 2010) (discussing assizes of bread and beer); Walton H. Hamilton, The Ancient Maxim Caveat Emptor, 40 YALE L.J. 1133, 1142-43 (1931).

140 Selden Society, 1 Select Pleas in Manorial and Other Seignorial Courts 8 (F.W. Maitland ed., 1974) (listing fines for several "[b]reakers of the assize"); id. at 11 (several identified as "[b]reakers of the assize," including two who "have gallons which are too small"); $i d$. at 18 (fines for breaking assize); $i d$. at $23 \&$ n.2 (several people fined, probably for violating assize of beer); $i d$. at $27 \&$ n.2 (same); $i d$. at 33 (several brewers fined for breaking assize of beer based on information presented by ale-tasters); id. at 88-89 (same); $i d$. at 113-14 (seller of beer failed to appear to answer charge of violating assize). 141 Statute of York 1318, 12 Edw. 2 c. 6 (Eng.) (applying to any "Officer in City or in Borough, that by reason of his Office ought to keep Assises of Wines and Victuals").

142 Id. (" $[\mathrm{S}]$ hall not merchandise for Wines nor Victuals, neither in Gross nor by Retale.").

143 Id. (reciting statutory goal of securing "the common profit of the People").

144 Peter Kellner \& William Harford Thomas, England, in Encyclopedia Britannica, https://www.britannica.com/place/England (last visited Nov. 28, 2017) (listing "Total Area" of 50,302 square miles); David Simpkin, Total War in the Middle Ages? The Contribution of English Landed Society to the Wars of Edward I and Edward II, in THE SOLDIER ExPERIENCE IN the Fourteenth Century 61, 68 n.26 (Adrian R. Bell et al. eds., 2011) (describing Arrowsmith map of 1815-1816 showing the division of England into forty historic counties).

145 The British National Archives indicates that the term "burrough" or "burh" referred to fortified towns. See Life in Towns and Villages, The National Archives, http:// www.nationalarchives.gov.uk/domesday/world-of-domesday/towns.htm (last visited Nov. 28, 2017). The 1086 Domesday Book reportedly recorded "112 towns or burroughs," and 
of the regulated activity, how could the King monitor local officials to ensure they respected the will of Parliament? One option would be to send royal judges throughout the country looking for evidence of statutory violations. ${ }^{146}$ The statute affirmed that "the King may assign his Justices to execute this Thing in Cities and Boroughs, when and where it pleaseth him." 147 But that option would not provide systematic or continuous oversight unless the King kept his judges constantly on the road.

Parliament's solution was to provide for qui tam enforcement of the conflict-of-interest provision, allowing common informers to sue the regulated officials. The statute granted standing to whoever would initiate the litigation, instructing the judiciary that "he that will sue [for a thing so forfeited] shall be received." 148 The legislation offered the informer a variety of judicial fora: "the Chancellor, Treasurer, Barons of the Exchequer, Justices of either Bench, and Justices assigned to take Assises."149 It also swept away potential procedural obstacles, specifying that judges should "admit such Plaints by Writs, and without Writs, and shall determine them." 150 If the evidence established the basis for a forfeiture, the statute directed that "the third part" of the forfeited merchandise "shall be delivered to the Party that sued the Offender, as the King's Gift."151 This qui tam remedy used a contingent-fee arrangement to supplement available law enforcement resources at no additional cost to the government. ${ }^{152}$ If the litigation was successful, the informer's bounty would come out of the proceeds and the remainder would be forwarded to the treasury. If the litigation was unsuccessful, the government owed the informer nothing.

The 1318 conflict-of-interest provision highlights three sometimes overlapping advantages that can flow from qui tam legislation directed at public officials. First, qui tam legislation can extend the reach of government law enforcement resources and allow more effective monitoring of the legality of highly decentralized government conduct. With the qui tam provision in place, any citizen learning of a violation could step forward and act as the King's agent to enforce the statute, in lieu of the more haphazard monitoring provided through occasional visits by royal judges. Second, litigation by private qui tam informers can overcome government officials' resistance to legal mandates, arising from conflicting personal or professional interests or

the number of towns more than doubled over the following 150 years, but the National Archives does not report how many of the towns would have been classified as burroughs. Id. See generally James Tait, The Medieval English Borough: Studies on Its Origins and Constitutional History (1936) (reviewing evidence concerning the origins and characteristics of towns classified as "boroughs").

146 Pollock \& Maitland, supra note 139, at 560 (noting royal justices were sometimes sent into English counties with commissions to accomplish particular tasks).

147 Statute of York 1318, 12 Edw. 2 c. 6 (Eng.).

148 Id. (alteration in original).

149 Id.

$150 I d$.

$151 I d$.

152 See Beck, supra note 108, at 541. 
divergent policy preferences. The 1318 statute imposed a regulation contrary to the economic interests of local officials. The qui tam provision created a significant threat of forfeiture to counter any economic incentive to violate the statute. Third, a system of qui tam enforcement can enhance public confidence in the integrity of law enforcement processes, reducing the risk that illegal conduct will go unaddressed and countering the suspicion that those in power can violate the law with impunity. These three advantages help explain many of the qui tam provisions Parliament directed at public officials over the succeeding centuries.

\section{Enhanced Monitoring of Decentralized Government Activity}

The deadly plague that swept through England in 1348-1350 reportedly took thirty to forty-five percent of the population, with even higher percentages succumbing in some parts of the country. ${ }^{153}$ The widespread mortality produced enormous economic consequences. ${ }^{154}$ In the 1349 Statute of Labourers, Parliament diagnosed the resulting economic problems as the product of a lazy and greedy working class:

Because a great Part of the People, and especially of Workmen and Servants, late died of the Pestilence, many seeing the Necessity of Masters, and great Scarcity of Servants, will not serve unless they may receive excessive Wages, and some rather willing to beg in Idleness, than by Labour to get their Living. ${ }^{155}$

From the perspective of the political elites, it was as if the real problem the plague created was to make it so much harder to get good help. Parliament's answer to the calamity was to adopt a wide-ranging system of compulsory labor combined with extensive wage and price controls. Those able to work and not otherwise employed could be compelled to serve at wages prevailing three years earlier, before the plague spread to England. ${ }^{156}$ Artisans were limited to charging prices that prevailed three years before and food merchants could only charge a "reasonable Price" designed to generate "moderate Gains, and not excessive." 157 Giving alms to a beggar was illegal if the person could work for a living. ${ }^{158}$

By any measure, the Statute of Labourers represented a highly ambitious regulatory undertaking, particularly in the mid-fourteenth century. Parliament sought to regulate most employment relationships throughout the country and most market transactions for consumer goods in ways that defied the laws of supply and demand. The statute's diverse provisions contained a

153 Mike Ibeji, Black Death, BBC (Mar. 10, 2011), http://www.bbc.co.uk/history/british /middle_ages/black_01.shtml.

154 See Statute of Labourers 1349, 23 Edw. 3 c. 1 (Eng.).

155 Id. Preamble.

156 Id. c. 1. Those already in service were not permitted to leave without permission or reasonable cause. Id. c. 2.

157 Id. c. 5-6.

158 Id. c. 7. 
variety of enforcement mechanisms, but we will focus on two distinct qui tam provisions included in chapter 6 regulating food prices, one directed at private conduct and the other at public officials. A food merchant found to have charged an excessive price would pay double the amount received "to the Party damnified, or, in Default of him, to any other that will pursue in this behalf."159 The statute thus deployed qui tam enforcement as a backup mechanism, allowing a common informer to sue only if the aggrieved individual failed to do so. The statute empowered mayors and bailiffs to hear claims against merchants and to levy the statutory penalty. ${ }^{160}$ A second qui tam provision, parallel to the first, targeted public officials. If mayors or bailiffs proved "negligent" in enforcing the statute, justices assigned by the King could require the official to pay three times the illegal price "to the Party damnified, or to any other in Default of him that will pursue." 161

According to one scholar, the King commissioned 671 royal judges between 1349 and 1359 to enforce the Statute of Labourers. ${ }^{162}$ Given the extent of the regulatory endeavor, however, Parliament also wanted the cooperation of mayors and bailiffs in enforcing the statute. The provision for suits by aggrieved parties provided a means to monitor both food vendors and local officials to ensure compliance with statutory obligations. The provision for qui tam enforcement further expanded the universe of people incentivized to seek out statutory violations. An aggrieved party who paid inflated prices might not want to file suit. Some "victims" of illegal price inflation might actually be coconspirators, willing to pay higher prices in exchange for access to scarce goods. ${ }^{163}$ The qui tam provisions of the Statute of Labourers greatly augmented enforcement resources directed at food merchants and also greatly increased monitoring of mayors and bailiffs for diligence in enforcing the statutory scheme.

Many other English qui tam statutes served a similar purpose of increasing the number of citizens monitoring the legality of decentralized government conduct. Late in the fourteenth century, for example, a practice arose in certain areas of demanding nine bushels in a "quarter" of grain, rather than the eight bushels specified by statute. ${ }^{164}$ Parliament provided that

159 Id. c. 6.

$160 I d$. (directing that the penalty be paid "to the Use of them at whose Suit such Offenders shall be convict," i.e., either the injured plaintiff or the common informer).

$161 I d$. After providing the treble damage award against mayors and bailiffs, the statute also warned that "nevertheless towards Us they shall be grievously punished." Id.

162 Bertha Haven Putnam, The Enforcement of the Statutes of Labourers During the First Decade After the Black Death 1349-1359, at 20-21 (1908).

163 Conventional economic wisdom suggests that price controls tend to produce economic shortages. Vedat Milor, Note, The Promotion of Economic Development Through Conflict and Dispute Resolution: Examples from Mexico and Malaysia, 35 STAN. J. INT'L L. 169, 199 (1999) ("It is well established that price controls create shortages and black marketeering.”); Cass R. Sunstein, Administrative Substance, 1991 Duke L.J. 607, 638 ("Government price-fixing will be inefficient and will produce a range of unintended harmful consequences, including misallocation of supply and demand, leading to scarcity.").

16415 Rich. 2 c. 4 (1391) (Eng.). 
someone buying grain at higher than eight bushels to the quarter would forfeit the grain to the King. ${ }^{165}$ To ensure that local officials enforced the rule, the statute provided that "the Mayor and Sheriffs of London" and mayors and bailiffs in other cities, boroughs, towns, and markets would incur "like Pain" at the suit of the King, a party, or "any other Person that will sue for the King" if the official did not give the statute "full and due Execution."166

A number of qui tam provisions over the ensuing centuries were directed at the "aulnager" and other officers involved in regulating cloth sold by English manufacturers. The Statute of Cloths in the mid-fourteenth century mimicked the enforcement scheme adopted a year earlier in the Statute of Labourers, deploying qui tam litigation as a backup to suit by an aggrieved party. Under the statute, "every Buyer of . . Cloth, or other that will sue" could receive half of the statutory forfeiture imposed upon proof that the aulnager "hath done any Fraud or Deceit in his Office."167 An early fifteenth-century statute allowed a qui tam informer to sue an aulnager who sealed cloth that did not meet statutory length and breadth requirements. ${ }^{168}$ In the second half of the fifteenth century, Parliament subjected the aulnager and another officer called the "keeper of the seal" to qui tam forfeitures for a more extended list of offenses, including improperly sealing cloth that violated statutory requirements, refusing to seal cloth that complied, charging higher fees than those provided by law, or refusing to show a commission upon request. ${ }^{169}$ Statutes in the sixteenth century established responsibilities of local "searchers" and "sealers" regulating the cloth trade, with qui tam forfeitures for a mayor who failed to appoint a town searcher and for improper sealing of cloth. ${ }^{170}$

The need to monitor decentralized government conduct also explains two statutes from the second half of the sixteenth century regulating fairs and markets to prevent sales of stolen horses. The first statute required the person in charge of a fair or market to provide an open space for sales of horses and appoint one or more individuals to oversee and maintain meticu-

$165 I d$.

$166 I d$.

167 Statute of Cloths 1350, 25 Edw. 3 c. 1 (Eng.). The statute also provided for private suit against a mayor, bailiff, or keeper who failed to execute the statute, but it did not specify that the resulting fine should be shared with the private litigant. Id.

16811 Hen. 4 c. 6 (1409) (Eng.) (allowing "every Person which will sue for the King, or for himself" to recover "the Fourth Part" of the $£ 10$ penalty for a first offense or the $£ 20$ penalty for a second offense).

1694 Edw. 4 c. 5 (1464) (Eng.); see also 8 Edw. 4 c. 1 (1468) (Eng.) (providing for qui tam forfeiture if an aulnager sealed cloths of improper size).

170 See An Act Touching the Making of Woollen Clothes 1557, 4 \& 5 Phil. \& M. c. 5, $\S 33$ (Eng.) (providing for forfeiture by town for improper sealing by searcher or sealer); $i d$. $\$ 34$ (providing a qui tam remedy to enforce all forfeitures in this statute or the previous statute); An Act for the True Making of Woollen Cloth 1552, 5 \& 6 Edw. 6 c. 6, $\S \S 41-42$ (Eng.) (providing for forfeitures for improperly sealed cloth); $i d$. $\$ 44$ (providing for forfeiture for failures of mayor, bailiff, or head officer to appoint searcher for town or city). 
lous records concerning each transaction. ${ }^{171}$ The statute provided for qui tam forfeitures if the person in charge of the fair or market did not appoint a toll gatherer to oversee the space for sales of horses, if the toll gatherer did not properly supervise and maintain records of transactions, and if the toll gatherer or bookkeeper did not deliver the records to be signed by the owner or officer in charge of the fair or market. ${ }^{172}$ A few decades later, Parliament adopted another qui tam provision to strengthen the statutory scheme, imposing a forfeiture if the responsible official did not know the seller of the horse or a person vouching for the seller. ${ }^{173}$

\section{Countering Official Resistance to Legislative Policies}

Government officials sometimes resist compliance with legislative directives due to conflicting economic or professional interests or policy differences with the legislature. The English Parliament repeatedly deployed qui tam provisions in such situations to counter officials' incentives for noncompliance. The 1318 statute discussed above-requiring local officials to refrain from selling merchandise they were responsible to regulateaddressed an economic conflict of interest. ${ }^{174}$ Compliance with the statute would undermine economic interests of any official positioned to profit from such sales. The statute's qui tam provision responded to the economic incentive to violate the rule. After 1318, an official contemplating illegal sales would have to consider both the possible profits from a violation and the possible losses if a citizen filed a qui tam action. Similarly, a statute from the early seventeenth century imposed a qui tam forfeiture on the steward of any court-leet or court-baron who personally received more than a small sum by virtue of a grant or lease of the court's profits. ${ }^{175}$ The statute sought to protect defendants from excessive fines imposed due to the financial interest of court officers. ${ }^{176}$ Parliament believed qui tam enforcement could counteract the stewards' financial incentive to violate the legislation. ${ }^{177}$

Legislative restrictions can also undermine an official's noneconomic interests. In the sixteenth century, King Henry VIII sought to limit the jurisdiction of the ecclesiastical courts, making it illegal in most circumstances for such a court to summon a person who resided in a different diocese. ${ }^{178} \mathrm{~A}$ judicial officer in an ecclesiastical court might chafe at this restriction on the tribunal's jurisdiction, which reduced the court's power and could interfere with the pursuit of justice in particular cases. Parliament's provision for qui

171 An Acte Agaynst the Byeng of Stolen Horses 1555, 2 \& 3 Phil. \& M. c. 7 (Eng.).

172 Id. $\S \S 2-3$ (forfeitures); $i d . \S 4$ (qui tam remedy).

173 An Acte to Avoyde Horse Stealinge 1588, 31 Eliz., c. 12, § 2 (Eng.)

174 See supra notes 142-43 and accompanying text.

175 An Acte that No Psonne Shalbe Cited Oute of the Dioc Where He or She Dwelleth Excepte in Ctayne Cases 1531, 23 Hen. 8 c. 9 (Eng.).

$176 I d$.

177 Id.

178 See id. 
tam enforcement gave court officials a financial reason to stay within the scope of their more limited statutory mandate. ${ }^{179}$

Qui tam legislation could also address the concern that policy differences might lead to underenforcement of a controversial statutory mandate. In the 1670 Act to Prevent and Suppresse Seditious Conventicles, Parliament sought to promote religious uniformity by penalizing individuals who participated in religious assemblies conducted "in other Manner then [sic] according to the Liturgy and practice of the Church of England." 180 The statute allowed qui tam litigation against participants in such illegal religious services. ${ }^{181}$ Parliament also provided qui tam remedies against certain officials with enforcement responsibilities, imposing mandatory reporting obligations on several temporal and spiritual officials. A "Constable[,] Headborough[,] Tythingman[,] Church warden[,] or Overseer of the Poore" credibly informed of an illegal meeting was required to seek a conviction under the statute, and could be sued for a forfeiture of $£ 5$ for willfully failing to perform his duty. ${ }^{182}$ A Justice of the Peace or Chief Magistrate who willfully failed to execute the Act faced a much larger one hundred pound forfeiture, half to the King and half to the use of the informer. ${ }^{183}$

The statute was highly controversial and provoked criticism from advocates of religious tolerance and from those sympathetic to Catholics and Protestant dissenters burdened by the legislation. ${ }^{184}$ Inclusion of qui tam provisions to enforce the statute against private citizens and to spur enforcement efforts by government officials reflected Parliament's expectation of resistance to the statutory policy. Those of us in the United States likely sympathize with the resisters because we disagree with Parliament's objective of securing religious uniformity by law, but any legislative tool can be put to good uses or bad. The key point here is that Parliament saw qui tam regulation of government officials as a means to ensure that its legal directives prevailed in a climate of policy disagreement.

\section{Bolstering Public Confidence in Governmental Processes}

Belief that government officials violate the law with impunity or that legal processes are untrustworthy can produce a corrosive public cynicism

179 See id.

180 An Act to Prevent and Suppresse Seditious Conventicles 1670, 22 Car. 2 c. 1, § 1 (Eng.).

$181 I d . \$ \S 1-2$.

182 Id. $\$ 10$.

183 Id. Two years later, Parliament sought to weed out "Popish Recusants" from government service by allowing qui tam prosecution of government employees who neglected to take an anti-Catholic oath and participate in an Anglican communion service. An Act for Preventing Dangers Which May Happen from Popish Recusants 1672, 25 Car. 2 c. 2, § 3-5 (Eng.).

184 Beck, supra note 108, at 593-95. 
that undermines voluntary legal compliance. ${ }^{185}$ Parliament often deployed qui tam regulation as a means of ensuring a remedy for government lawlessness, particularly in situations where one might expect a heightened level of public attention or concern. For instance, a desire to maintain public confidence in the integrity of governmental functions appears to underlie a set of statutes regulating the activities of purveyors who acquired goods for the royal household. A 1362 statute noted complaints about purveyors for the royal family (including the King's eldest son) and other noble families. ${ }^{186}$ The statute changed the name of procurement agents from "purveyor" to "buyer," limited the office to the households of the King and Queen, and required buyers to pay market prices. ${ }^{187}$ The statute authorized "takings" as necessary to supply the royal households and specified a method for adjudicating price, but buyers were instructed to pursue such takings "in convenient and easy Manner, without Duress, Compulsion, Menace, or other Villainy." 188 The legislation provided a treble damage cause of action to a party "charge[d]" or "grieve[d]" by a malicious taking, purchase, or arrangement for carriage. ${ }^{189}$ The statute included qui tam enforcement as a backup, providing that "if the Party will not sue, he that will sue for the King shall have the Third Peny of that which shall be recovered for his Labour."190 A later enactment provided a qui tam remedy against any purchaser, including the King's purveyor, who bought grain at a measure of greater than eight bushels per quarter. ${ }^{191}$

One common area of public concern is the integrity of tax collection efforts. Parliament repeatedly employed qui tam enforcement to ensure that collected funds made their way to the public treasury for the intended purpose. In 1677, Parliament adopted a wide-ranging tax bill to collect funds for war with France. Under the statute, a local collector who kept any part of the money or paid it to an unauthorized recipient would forfeit $£ 5$ per offense, and a Receiver General would forfeit $£ 500$ each time he or his deputy failed

185 See, e.g., Gonzalo Lira, The Coming Middle-Class Anarchy, Bus. Insider (Oct. 12, 2010), http://www.businessinsider.com/coming-middle-class-anarchy-2010-10 ("If a big enough proportion of the populace-not even a majority, just a largish chunk-decides that it's just not worth following the rules anymore, then that society's days are numbered . ...”).

18636 Edw. 3 c. 2 (1362) (Eng.).

$187 I d$.

$188 I d$.

189 Id. c. 3. The statute also forbade the buyer to take payment from a person for "sparing to be made," but it is not clear whether this provision was enforceable through private litigation. Id.

$190 I d$.

19111 Hen. 6 c. 8 (1433) (Eng.). An earlier statute had applied the eight bushel per quarter standard to purveyors, but the statute may have only allowed suit by an aggrieved party. 1 Hen. 5 c. 10 (1413) (Eng.) ("[T]he Party which will sue, have an Action grounded upon the Case."). 
to pay collected funds to the Exchequer. ${ }^{192}$ These forfeitures were payable "to him or them that shall sue for the same."193 A 1694 statute for duties on ships and liquor, again premised on a need for revenue to fight the French, contained a similar provision. ${ }^{194}$ If the commissioners and governors responsible for collecting the duties diverted funds (or failed to keep accounts), they were required to pay the amount misapplied to any qui tam informer who would sue. ${ }^{195}$

Qui tam legislation became a common means of enforcing disqualification statutes that limited who could serve in Parliament. In 1742, various government officers were prohibited from becoming members of Parliament, with a forfeiture imposed for each day the person sat or voted in the legislature. ${ }^{196}$ Use of qui tam enforcement in this context cannot be explained by a need for information. The facts forming the basis for the forfeiture-the holding of a public office and service in Parliament-would be matters of public record. The most plausible explanation for qui tam enforcement in this context is to make certain that enforcement of the statute could not be blocked by public officials allied with the violator. A 1782 disqualification statute similarly used qui tam litigation to bar members of Parliament who had an interest in a public contract. ${ }^{197}$

Qui tam enforcement was also employed to monitor the activities of private individuals and corporations performing public functions. A fourteenth-century statute imposed a qui tam forfeiture on a juror who accepted a gift in exchange for his vote. ${ }^{198}$ A number of eighteenth-century statutes permitted qui tam actions against goldsmiths, silversmiths, and their guilds for offenses connected to the assaying or marking of metal. ${ }^{199}$

192 An Act for Raising Money by a Poll and Otherwise to Enable His Majestie to Enter into an Actuall Warr Against the French King and for Prohibiting Severall French Commodities 1677, $29 \& 30$ Car. 2 c. $1, \S 59$ (Eng.).

193 Id.

1945 \& 6 Wm. \& M. c. 20, §§ 1, 13 (1694) (Eng.).

$195 I d . \S 13$. A later provision of the statute provided for qui tam forfeiture by bank officers who lent money to the royal family. Id. § 29.

196 An Act to Exclude Certain Officers from Being Members of the House of Commons 1742, 15 Geo. 2 c. 22, § 2 (Eng.).

197 An Act for Restraining Any Person Concerned in Any Contract, Commission, or Agreement, Made for the Publick Service, from Being Elected, or Sitting and Voting as a Member of the House of Commons 1782, 22 Geo. 3 c. 45, $\S \S 2,9$ (Eng.).

19834 Edw. 3 c. 8 (1360) (Eng.).

199 An Act for Appointing Wardens and Assaymasters for Assaying Wrought Plate in the Towns of Sheffield and Birmingham 1773, 13 Geo. 3 c. 52, § 4 (Eng.) (providing qui tam remedy); id. $\S 6$ (bond and oath of assayers); id. $\$ 19$ (forfeiture of assayer for improper marking or inappropriate disclosure of designs); $i d . \$ 29$ (recovery on bond for neglect or fraud by assayer); An Act for the Better Preventing Frauds and Abuses in Gold and Silver Wares 1739, 12 Geo. 2 c. 26, $\S 9$ 9, 22 (Eng.) (forfeiture for failing to submit required records); An Act for Appointing Wardens and Assay Masters for Assaying Wrought Plate in the Cities of Bristol Chester and Norwich 1700, 12 \& 13 Will. 3 c. 4, $\$ 6$ (Eng.) (forfeiture by company of goldsmiths or silversmiths for fraud in assaying or marking). 


\section{B. Early State Qui Tam Statutes Regulating Public Officials}

Our review of British qui tam statutes directed at public officials suggested that such legislation could typically be explained in terms of one or more of three broad objectives: (1) monitoring decentralized government activity to ensure compliance with directives from a central government, (2) countering government officials' economic and other incentives to violate applicable rules, and (3) bolstering public confidence in the lawful performance of important governmental functions. Those same objectives prove similarly helpful in explaining the extensive use of qui tam legislation to regulate government activity in the eighteenth-century American colonies and states. Our survey of state legislation will be illustrative rather than exhaustive, sampling a wide array of statutes in which legislatures in all thirteen American colonies and states used private qui tam informers to monitor the lawfulness of government conduct.

\section{Monitoring Decentralized Government Activity}

Governmental functions in England were divided between hierarchically superior central authorities like the King and Parliament and inferior local authorities like mayors, bailiffs, and sheriffs. This structural allocation of authority was often replicated in the early American colonies and states. A centralized legislative assembly would generate laws with statewide application, while local administration would be overseen by town or county officials. Consequently, the American context generated a comparable problem concerning how to monitor decentralized government activities to ensure compliance with centralized directives. Borrowing from English practice, American governments often turned to qui tam legislation for that purpose.

\section{a. Centralized Regulation of Local Administration}

The newly independent state of North Carolina enacted legislation in 1777 to overhaul the state's system of caring for the poor. ${ }^{200}$ Since impoverished citizens resided throughout the state, the task of caring for those in need fell to local "overseers of the poor," selected at the county level. The North Carolina legislation is remarkable for the large number of statutory forfeitures directed at five distinct categories of local public officials. The county sheriff could be fined $£ 10$ for neglecting to advertise the date for initially electing overseers of the poor, ${ }^{201} £ 10$ for failing to select and advertise a day for the overseers' first meeting, ${ }^{202} £ 5$ for each overseer he failed to summon to that initial meeting, ${ }^{203}$ forty shillings for failing to summon an

200 An Act for Making Provision for the Poor, and for Other Purposes (1777), in James Iredell, Laws of the State of North Carolina, c. 7, § 1 (Hodge \& Wills eds., 1791) [hereinafter Laws of North Carolina].

201 Id. $\S 2$.

$202 I d . \S 1$.

$203 I d$. 
overseer to a subsequent meeting, ${ }^{204}$ and $£ 20$ for failing to advertise at least ten days in advance the date for the triennial election of new overseers. ${ }^{205}$ Those elected as overseers could forfeit $£ 5$ if they failed to take the oath to qualify for office, ${ }^{206}$ forty shillings if they missed a meeting without sufficient cause, ${ }^{207}$ and $£ 20$ for refusing to serve as a county warden when selected by the other overseers. ${ }^{208}$ The county warden and the clerk hired by the overseers could forfeit $£ 10$ for failure to maintain financial records and make them available for annual public inspection. ${ }^{209}$ The warden could also forfeit $£ 20$ for refusing to care for a poor person settled in the county or returned from another county. ${ }^{210}$ The clerk of the county court would forfeit $£ 20$ for neglecting to furnish the wardens with an inventory of the county's taxable property. ${ }^{211}$ All of these forfeitures could be enforced through qui tam actions, with half of the money allocated to the use of the informer and half to benefit the local poor. ${ }^{212}$ One advantage of this extensive system of qui tam enforcement was the elimination of the need for centralized oversight. Assuming local informers were willing to bring qui tam suits and courts were willing to implement the statute, the system could operate as intended without supervision by state officials.

A much more selective use of qui tam enforcement can be seen in a 1789 Massachusetts law establishing a statewide system of public education. The Massachusetts Constitution of 1780 stressed the importance of public education and empowered the legislature to require creation of schools. ${ }^{213}$ Acknowledging the "dispersed situation of the [commonwealth's] inhabitants," the 1789 legislation required the formation of local school districts and the hiring of public schoolmasters. ${ }^{214}$ Towns or districts that failed to

$\begin{array}{ll}204 & \text { Id. } \$ 7 . \\ 205 & \text { Id. } \$ 20 . \\ 206 & \text { Id. } \$ \S 3-4 . \\ 207 & \text { Id. } \$ 7 . \\ 208 & \text { Id. } \$ 5 . \\ 209 & \text { Id. } \S 6 . \\ 210 & \text { Id. } \S 23 . \\ 211 & \text { Id. } \$ 12 .\end{array}$

212 Id. $\$ 19$ (allowing, since no different allocation was specified, all of the forfeitures to be recovered "one Half to the Use of the Informer, the other half to the County Warden, for the use of the Poor of the County"). The statute also provided that the overseers would be liable to an aggrieved party if they failed to raise sufficient taxes to meet their financial obligations. Id. $\S 11$. The wardens could sue sheriffs or tax collectors who failed to collect or account for tax revenues, $i d$. $\S 13$, or a private housekeeper who entertained a poor person without giving notice. Id. $\S 23$.

213 Mass. Const. of 1780, pt. I, art. III. The constitution highlighted instruction in "piety, religion and morality" as an aid to "the good order and preservation of civil government." Id. It empowered the legislature to require "the several towns, parishes, precincts, and other bodies-politic, or religious societies, to make suitable provision, at their own expense," for "public protestant teachers." Id.

214 An Act to Provide for the Instruction of Youth, and for the Promotion of Good Education (1789), in Acts and Laws of the Commonwealth of Massachusetts, ch. 19, at 416 (Wright \& Potter Printing Co. 1894) [hereinafter Laws of Massachusetts]. 
comply could be compelled to pay money to the county treasury, but this penalty included no provision for qui tam enforcement. ${ }^{215}$ The statute did include two regulations of schoolmasters enforceable through qui tam litigation. A person who operated a (presumably private) school for children "in the most early stages of life" without a certificate from the local selectmen would forfeit twenty shillings, half to the informer. ${ }^{216}$ A more substantial penalty of $£ 20$ per month could be collected from any schoolmaster, including a public schoolmaster, who was not a citizen of one of the United States. ${ }^{217}$

Some qui tam legislation enforced duties relating to appointment and qualification for office. A Massachusetts town could forfeit $£ 50$ in a qui tam action if it failed to appoint a committee to implement a law to prevent overharvesting of certain species of fish. ${ }^{218}$ An elected fish warden in New Hampshire could face a qui tam forfeiture for refusing the office. ${ }^{219}$ Maryland and South Carolina surveyors could suffer qui tam forfeitures for conducting surveys before taking the oath of office. ${ }^{220}$

$215 I d$. at 418-19 ("[P] enalties . . shall be levied by warrant from the Supreme Judicial Court, or Court of General Sessions of the Peace for the County.").

216 Id. at 420.

217 See id. ("[H]alf . . to the use of the person who shall sue for the same.").

218 See An Act to Prevent the Destruction and to Regulate the Catching of the Fish Called Salmon Shad \& Alewives in the Rivers and Streams in the Counties of Cumberland and Lincoln, and to Repeal all Laws Heretofore Made for that Purpose (1788), in LAws of Massachusetts, supra note 214, ch. 73, at 157, 162.

219 See An Act in Addition to, and in Amendment of an Act, Intitled "An Act to Prevent the Destruction of Salmon, Shad \& Alewives in Merrimac River, \& for Repealing all the Laws Heretofore Made for that Purpose" (1795), in 6 Laws of New HampshiRe InCLuding Public and Private Acts, Resolves, Votes, Etc. Edited and Published Under the Direction of the Secretary of State Second Constitutional Period 1792-1801, at 221-22 (1917) [hereinafter LAws of New HAMPSHIRE] ("[I]f any person legally chosen by any of said Towns shall neglect or refuse, after being lawfully notified of his appointment to take the Oath prescribed by this Act or execute the Office he shall forfeit \& pay Ten Dollars to any Person who will sue for the same, with cost as aforesaid.").

220 See An Act to Ascertain the Fees of the Surveyor General for the Time Being and His Deputies; and to Prevent Any Irregularities Being Committed in the Office of the Said Surveyor General, or by Any of His Deputies (1733) [hereinafter Fees of the Surveyor General Act], in 3 The Statutes at Large of South Carolina; Edited, Under Authority of the Legislature, $\$ 7$, at 343-47 (Thomas Cooper ed., 1838) [hereinafter Statutes of South Carolina]; Thomas Herty, A Digest of the Laws of Maryland, Being an Abridgment, Alphabetically Arranged, of All the Public Acts of Assembly Now in Force, and of General Use, from the First Settlement of the State, to the End of November Session 1797, Inclusive, with References to the Acts at Large 496 (1799) [hereinafter Herty, Laws of MARYLAND]; see also An Act Requiring the Agents of the Lord Baltemore to Certifie into the Secretary's Office the Instructions and Conditions of Plantations, with the Fees by Them Demanded; and Obliging His Lordship's Deputy Surveyors to Qualifie Themselves According to Law (1715) [hereinafter An Act Requiring the Agents], in Acts of Assembly, Passed in the Province of Maryland, from 1692, to 1715, at 58 (1723) [hereinafter ACTS OF MARYLAND] (subjecting surveyors to qui tam action for failure to take the oath of office). 
Other qui tam statutes enforced duties relating to administrative tasks like conducting meetings and keeping records. A Rhode Island town clerk who failed to give notice of a town meeting and a town-sergeant or constable who failed to serve the notice on individual freemen were subject to qui tam forfeitures. ${ }^{221}$ A New Hampshire constable who failed to give notice of a town meeting could forfeit $£ 10$ "to any inhabitant of the town who will sue for the same," one-half "to the use of the Town and the other half to the use of the prosecutor." 222 A Massachusetts town clerk or county register of deeds could face qui tam prosecution for neglecting record-keeping requirements with respect to lost property or stray animals. ${ }^{223}$ A Maryland clerk or register could suffer a qui tam forfeiture for allowing public records to be removed from the office overnight. ${ }^{224}$ South Carolina surveyors were required to record surveying instructions in a government office. ${ }^{225}$

It was also common to use qui tam enforcement to monitor financial matters. Colonial Maryland regulated fees charged by a variety of state and local officials, with offenders obliged to pay treble damages to the party aggrieved, plus an additional forfeiture to be split between the crown and "the Party or Parties that shall sue for the same."226 Officers and agents of Lord Baltimore, the Lord Proprietor, faced a qui tam action if they did not post information including fees charged. ${ }^{227}$ South Carolina surveyors could be sued for charging higher fees than provided by law. ${ }^{228}$ Commissioners of a Maryland county court who took a bond from a sheriff could suffer a qui tam forfeiture if they failed to transcribe and transmit the bond to the appropriate office within two months. ${ }^{229}$ In Rhode Island, an officer who retained money paid in fines and forfeitures for more than three months could be sued by a qui tam informer for three times the amount withheld. ${ }^{230}$

221 See An Act Declaring Towns to be Bodies Corporate, Establishing Town-Councils, Regulating Town-Meetings, and Prescribing the Manner of Recovering Debts Due from Towns, in The Public Laws of the State of Rhode-Island and Providence Plantations, as Revised by a Committee, and Finally Enacted by the Honourable General Assembly, at Their Session in January, 1798, § 11, at 329-30 (Carter \& Wilkinson eds., 1798) [hereinafter LAws of RHODE ISLAND].

222 An Act for Regulating Towns and the Choice of Town Officers (1791), in 5 LAws OF New Hampshire, supra note 219, ch. 41, at 592-93 [hereinafter An Act for Regulating Towns].

223 See An Act Respecting Lost Goods \& Stray Beasts (1788), in Laws of MassachuSETTS, supra note 214 , ch. 55, at $86,87-88$.

224 See Herty, Laws of Maryland, supra note 220, at 444.

225 See Fees of the Surveyor General Act, supra note 220, $\$$ 6, 10.

226 An Act for the Limitation of Officer's Fees, in Acts OF MARYLAND, supra note 220, at 55.

227 See An Act Requiring the Agents, supra note 220, at 58.

228 See Fees of the Surveyor General Act, supra note 220, $§ 1$.

229 See An Act for the Direction of the Sheriff's Office, and Restraining Their Ill Practices Within This Province (1715), in Acts of Maryland, supra note 220, at 177-79.

230 See An Act to Prevent the Detention of Fines from the Proper Offices (1794), in LAws of RhODE Island, supra note 221, $\$ 1$, at 421-22. The statute obliged the officers from whom the money was withheld to enforce the statute. Id. $\S 2$. However, this did not 
American qui tam legislation in the eighteenth century enforced a wide variety of other duties. A New Hampshire sheriff or constable who neglected to serve a lawful precept (a writ or warrant) after tender of payment could be sued for a forfeiture by a qui tam informer or, in the absence of a private suit, indicted for the forfeiture to the use of the county. ${ }^{231}$ A New Hampshire town officer appointed to measure wood sold by the cord would forfeit thirty shillings for neglecting to measure wood brought to him. ${ }^{232}$ The selectmen of a Connecticut town were subject to a qui tam penalty if they failed to provide a pound to restrain stray animals, ${ }^{233}$ and for each month they failed to provide the town constable a black staff with the state's coat of arms on the head. ${ }^{234}$ Colonial New Jersey constables could be sued by qui tam informers for failure to perform duties connected with issuance of bills of credit to increase the money supply. ${ }^{235}$ In Massachusetts, the keeper of a lighthouse could forfeit $£ 100$ for failing to keep the lights burning and visible to ships from sunset to sunrise, two-thirds payable to "the person or persons who shall inform of such neglect." ${ }^{236}$ A colonial sheriff in Maryland could forfeit a quantity of tobacco in an action by a qui tam informer if he delayed delivery

supersede the provision for qui tam enforcement. Id. $§ 1$ ("[O]ne moiety thereof to the use of the person who shall sue for the same.").

231 See An Act Prescribing the Duty and Regulating the Office of Sheriff (1791), in 5 Laws of New Hampshire, supra note 219, ch. 44, at 608 [hereinafter An Act Prescribing the Duty and Regulating the Office of Sheriff] (providing for forfeiture of $£ 10$ within three months to "any person who will sue for the same" or, in the absence of a private suit, recovery by the county through indictment within a year). A "precept" is "[a] writ or warrant issued by an authorized person demanding another's action, such as a judge's order to an officer to bring a party before the court." Precept, Black's LAw Dictionary (10th ed. 2014). A person falsely pretending to be a sheriff or peace officer could also be sued for a qui tam forfeiture. See 5 Laws of New Hampshire, supra note 219, ch. 44, at 609.

232 See An Act to Prevent the Fraud in Cord Wood Exposed to Sale (1791), in 5 Laws of New HAMpshire, supra note 219, ch. 9, at 758 (stating that forfeiture "to be recovered and appropriated in manner as beforementioned"; prior paragraph provided for forfeiture by person who bought or sold unmeasured wood "one half of which sum shall be for the use of the town or place in which the same is so bought \& sold, the other half to the use of the person suing for the same").

233 See An Act for Providing and Maintaining Pounds, and for Regulating the Impounding Creatures, and for Preventing Rescues and Pound Breach, in Acts AND Laws of the State of Connecticut, in America, § 3, at 344 (Hartford, Hudson \& Goodwin 1802) [hereinafter Laws of Connecticut].

234 See An Act Relating to Constables, in Laws of Connecticut, supra note 233, § 15, at 119-20.

235 See An Act for Making Forty Thousand Pounds in Bills of Credit (1735), in Laws of the Royal Colony of New Jersey 1703-1745, at 476-77; An Act for Striking One Hundred Thousand Pounds in Bills of Credit, and Directing the Mode for Sinking the Same (1774), in Laws of the Royal Colony of New Jersey, 1770-1775 (1986), at 219 [hereinafter Laws of the Colony of New Jersey].

236 An Act Provision for the Building and Maintaining Light Houses on the Sea Coast of This Commonwealth, and for Repealing All Laws Heretofore Made for That Purpose (1787), in Acts and Laws of the Commonwealth of Massachusetts 1786-1787, ch. 31, at 597 (Wright \& Potter Printing Co. 1893) [hereinafter Acts of Massachusetts]. 
of a royal or official letter or refused to give a receipt when passing the letter along, ${ }^{237}$ or if he failed to read in the county court an act concerning regulation of slaves. ${ }^{238}$ While use of qui tam regulation to supervise local government administration could be quite eclectic in the eighteenth-century American states, we will observe below a number of recurring patterns.

\section{b. Road Maintenance and Construction Obligations}

Legislators in the eighteenth century often turned to qui tam supervision of road construction and maintenance activities. Early American governments did not create centralized highway departments of the sort common today. The task of road maintenance was instead delegated to local governments. Officials responsible to carry out road construction and maintenance functions were sometimes monitored and incentivized through qui tam legislation.

Selective use of qui tam monitoring can be seen in a 1774 New Jersey statute that overhauled the system of road construction and maintenance throughout the colony. ${ }^{239}$ The statute imposed a number of legal duties on public officials, some enforceable by government officials and others enforced through qui tam litigation. The law required every city, town, and precinct to annually elect two surveyors of the highways and at least two overseers of the roads. ${ }^{240}$ If a surveyor or overseer did not take the oath of office, he could forfeit $£ 5$ to the local tax collector to use for road and bridge repair, but this provision did not authorize suit by a private party or provide for a private litigant to share in the forfeiture. ${ }^{241}$ The same enforcement mechanism applied to a forty shilling forfeiture if the town clerk failed to post notices with the names of those elected, a $£ 5$ forfeiture by the clerk of the peace if he neglected record-keeping requirements with respect to new roads approved by the surveyors, and a forty shilling forfeiture if tax assessors or collectors neglected revenue-raising functions. ${ }^{242}$ Other provisions allowed overseers to recover highway-related funds from constables ${ }^{243}$ and enabled

237 See An Act for the More Speedy Conveying Publick Letters and Packets of This Province, and Defraying the Charge Thereof; and to Prevent Abuses of Breaking Open and Concealing Any Letters Whatsoever (1713), in Acts of MARYLAND, supra note 220, at 73-75.

238 See Herty, Laws of Maryland, supra note 220, at 381.

239 See An Act for Regulating Bridges and Roads (1774), in Laws of the Colony of New Jersey, supra note 235, at 178.

$240 I d$. at $178,182$.

241 Id. This provision did not explicitly allow enforcement by the tax collector, but did provide for the money to be paid to that official. Id. at 178. It did not make provision for qui tam enforcement, neither authorizing suit by a private litigant nor providing for the forfeiture to be split with that person. Id.

242 Id. at 179-80, 182, 192.

$243 I d$. at 187. 
tax collectors to recover excess bridge funds and related forfeitures from their predecessors. ${ }^{244}$

In addition to the duties enforceable by public officials, the $1774 \mathrm{New}$ Jersey statute used qui tam informers to monitor certain responsibilities of elected surveyors and overseers. A surveyor who neglected duties connected with a petition to open a new road or to alter an existing road could forfeit $£ 5$ in a qui tam action. ${ }^{245}$ An overseer who failed to perform duties relating to road inspection and maintenance could forfeit $£ 3$, recoverable by a qui tam informer. ${ }^{246}$ An overseer also incurred a forfeiture if he "connive[d] at" letting a private road worker request a reward from a traveler, excused someone from working "for drink," or got drunk when he should work. ${ }^{247}$ The overseer was likewise subject to suit if he neglected to enforce forfeitures incurred by others. ${ }^{248}$ These forfeitures imposed on the overseer could be recovered "by any Person whatsoever, One Half to the Use of the Prosecutor." 249 The practice of using qui tam litigation to enforce the duties of overseers and surveyors was not an innovation in the 1774 statute, but instead carried forward a practice that stretched back at least to a 1716 enactment on the same subject. ${ }^{250}$

Qui tam enforcement of road maintenance obligations was common in other states. Selectmen in Connecticut towns could be sued by informers if they failed to maintain sign posts and milestones. ${ }^{251}$ A North Carolina over-

$244 I d$. at 189-90. Other provisions of the statute imposed penalties for private misconduct, enforceable by public officials, with only one providing for qui tam litigation as a backup enforcement method. An overseer was empowered to enforce a forfeiture when a citizen failed to provide required assistance in road maintenance activities, with the overseer keeping half of the funds recovered. Id. Other forfeitures applied to those who filled in drainage ditches, who failed to remove certain dead trees near the road, who defaced or destroyed road markers, or who blocked or narrowed certain roadways. Id. at 184-86, 189-90. A person who left open or destroyed a gate, or who drove through private lands outside the roadway, was liable for a forfeiture in addition to damages for any injured party. Id. at 186-87. A small forfeiture applied when citizens assisting with road maintenance requested money, drink, or rewards from travelers. Id. at 183-84. This latter provision deployed qui tam enforcement as a backup to enforcement by a public official, allowing recovery "by the Overseer, or any other Person who shall prosecute the same, One Third for his own Use." Id. at 184.

$245 I d$. at 181 ("[T] o be recovered by any Person who will sue for the same . . paid One Half to him who shall sue for the same to Effect.”).

$246 I d$. at 183.

247 Id. at 184.

$248 I d$.

$249 I d$

250 See An Act for the Better Laying Out, Regulating and Preserving Public Roads and High-ways Thro'-out This Province (1716), in The Acts of the General Assembly of the Province of New-Jersey, from the Time of the Surrender of the Government in the Second Year of the Reign of Queen Anne, to This Present Time, Being the Twenty Fifth Year of the Reign of King George the Second 48-56 (1752) [hereinafter Acts of the Province of New Jersey].

251 See An Act for Erecting and Continuing a Sign-post in Each Town in This State, in Laws of Connecticut, supra note 233, $\$ 1$, at 395 (“[O]ne Half to the Complainer that 
seer of roads faced possible qui tam litigation if he refused appointment to the position, ${ }^{252}$ neglected to maintain signs at forks in the road, ${ }^{253}$ or failed to keep roads and bridges clear and repaired. ${ }^{254}$ New York likewise authorized qui tam prosecution of a person neglecting or refusing the office of overseer of roads, 255 while New Hampshire selectmen were subject to qui tam forfeitures if they neglected to establish post-guides at intersections. ${ }^{256}$

\section{c. Qui Tam Regulation of Judicial Administration}

American governments in the eighteenth century often used qui tam legislation to ensure the proper functioning of the legal system. Such statutes sometimes enforced the initial steps necessary to qualify for offices in judicial institutions-taking oaths and, for some roles, posting bond. In North Carolina, a qui tam informer could keep half of the $£ 100$ forfeiture imposed on someone who presumed to act as a justice of the peace or justice of a county court without first taking the prescribed oath of office. ${ }^{257}$ Virginia adopted the same rule for justices of the peace and magistrates of county or corporation courts, backed by a forfeiture of $\$ 1000 .{ }^{258}$ The clerk

shall prosecute the same within six Months after such Neglect, and the other Half to the County Treasury; which Fine shall be recoverable of the Select-men."); An Act to Oblige the Several Towns on the Post-Roads, to Erect Monuments, Shewing the Distances from the Several County Towns of Said Roads, in Laws of Connecticut, supra note 233, § 2, at 319 ("[O]ne Half to him or them who shall prosecute the same to Effect, the other Half to the Treasury of the Towns where such Select-men belong.”).

252 See An Act to Empower the County Courts of Pleas and Quarter-Sessions of the Several Counties in This State, to Order the Laying out Public Roads, and to Establish and Settle Ferries, and to Appoint Where Bridges Shall Be Built, and to Clear Inland Rivers and Creeks (1784), in Laws of North Carolina, supra note 200, ch. XIV, § IX, at 534 (“[T]o be recovered and applied as other Fines and Forfeitures by this Act directed.”).

253 Id. $\S \mathrm{XI}$, at 534 ("[T] o be recovered before any Justice of the Peace, and applied as other Fines in this Act are directed.").

$254 I d$. $\S$ XIV, at 535 ("[T] o be recovered by a Warrant from any Justice of the Peace by any Person taking out the same, and to be applied to his own Use.”).

255 See An Act for Dividing the Counties of This State into Towns (1788), in 2 Laws of the State of New York: Comprising the Constitution, and the Acts of the Legislature, Since the Revolution, from the First to the Fifteenth Session, Inclusive, ch. LXIV, § XIII, at 170 (Thomas Greenleaf ed., 1792) [hereinafter LAws of NEw York] (moiety of forfeiture "to the use of any person who shall prosecute the same to effect").

256 See An Act to Establish Post-Guides and to Facilitate Traveling in and Through This State (1792), in 6 Laws of New Hampshire, supra note 219, ch. 19, at 66-67 (giving "one half to the use of the prosecutor or Informer").

257 See An Act for Establishing Offices for Receiving Entries of Claims for Lands in the Several Counties Within This State, for Ascertaining the Method of Obtaining Titles to the Same, and for Purposes Therein Mentioned (1777), in Laws of North Carolina, supra note 200 , ch. I, § LVI, at 309 .

258 See An Act to Reduce into One, the Several Acts Concerning the County and Other Inferior Courts of This Commonwealth (1792) [hereinafter An Act Concerning Inferior Courts], in A Collection of All Such Acts of the General Assembly of Virginia of a Public and Permanent Nature, as Are Now in Force, ch. LXVII, § II, at 90 (Augustine Davis ed., 1794) [hereinafter Acts of Virginia]. A forfeiture of $\$ 1500$ applied if someone 
of a Virginia county court could forfeit $\$ 1500$ for executing the office without an oath and $\$ 600$ for doing so without posting an adequate bond, both enforceable by qui tam litigation and accompanied by terms of imprisonment. ${ }^{259}$ A Virginia county coroner faced a qui tam forfeiture if he executed a writ prior to taking the oath of office and securing a bond. ${ }^{260}$

Some states used qui tam legislation to supervise issuance and execution of writs. A North Carolina clerk who issued a writ without taking adequate security or keeping specified records would forfeit $£ 100$ to the defendant plus an additional $£ 50$, "one Half to the Use of the Person suing for the same, the other Half to the Use of the Poor of the County."261 A Maryland county clerk who delivered blank writs to an attorney, sheriff, or other person could suffer a forfeiture of tobacco, half to the government and half to the informer. ${ }^{262}$ A North Carolina sheriff who neglected to execute a writ or other process without sufficient cause was required to pay $£ 50$ to the aggrieved party; however, if the sheriff executed a "false [r] eturn," he had to pay $£ 50$, "one Moiety thereof to the Party grieved, and the other Moiety to him or them that will sue for the same."263 A New York sheriff would forfeit $£ 100$ at the suit of a qui tam informer for executing a writ of replevin notwithstanding an unadjudicated claim of ownership by the person in possession of the property. ${ }^{264}$ A New York sheriff executing a writ of fieri facias or other writ of execution could face a qui tam prosecution if he sold property without proper notice or outside of authorized hours. ${ }^{265}$ A New Jersey con-

acted as a judge of the General Court without first taking the oath, but this statute did not include a provision for qui tam enforcement. See An Act Reducing into One, the Several Acts and Parts of Acts Concerning the General Court, and Prescribing the Manner of Proceeding Therein in Certain Cases (1792), in Acts of Virginia, supra, ch. LXVII, § I, at 76.

259 See An Act to Reduce into One, All Acts and Parts of Acts Respecting County and Corporation Clerks (1792), in ACTs of VirginIA, supra note 258, ch. LXX, §§ I, III \& VI, at 101-02 [hereinafter An Act Respecting Clerks].

260 See An Act Concerning Coroners (1791), in Acts of Virginia, supra note 258, ch. LXXXI, § V, at 132 .

261 An Act Directing the Clerks of the Several Courts of Record Within This State as to Their Duty in Office with Respect to Issuing Writs (1787), in Laws of North Carolina, supra note 200 , ch. XIX, § III, at 619.

262 See Herty, Laws of Maryland, supra note 220, at 175 ("on penalty of 6000lb. tobacco; one half to the support of government, the other to the informer").

263 An Act for Appointing Sheriffs, and Directing Their Duty in Office, and for Obliging the Late Sheriffs and Collectors of Public Monies Who Are in Arrear, to Account for and Pay the Same, and Other Purposes (1777), in Laws of North Carolina, supra note 200, ch. VIII, § V, at 331; see also The Earliest Printed Laws of New Jersey, 1703-1722, at 14 (John D. Cushing ed., 1978) [hereinafter Laws of New Jersey] (referencing English law from the tenth and eleventh year of King William the Third imposing qui tam forfeiture if sheriff or other officer violated statutory restrictions on returns).

264 See An Act to Prevent Abuses and Delays in Actions of Replevin (1788), in 2 Laws OF New York, supra note 255, ch. V, § VI, at 7.

265 See An Act to Regulate Sales on Execution (1790), in 2 Laws of New York, supra note 255 , ch. LVII, $§$ I-II, at 330 . 
stable could pay a $£ 5$ qui tam forfeiture if he violated statutory duties relating to summoning jurors and executing judgments. ${ }^{266}$

Qui tam legislation was sometimes deployed to promote good record keeping by judicial officers. A Rhode Island justice of the peace or his estate was required to deliver official papers and records to the town clerk within six months after he left office or died, subject to a qui tam forfeiture for each month's delay. ${ }^{267}$ On removal from office or death, a Massachusetts justice of the peace or his estate had three months to lodge official papers and records with the clerk of the court of common pleas, subject to a variable qui tam forfeiture, with a larger forfeiture imposed for anyone who knowingly destroyed, defaced, or concealed records of a deceased justice. ${ }^{268}$ The clerk of a Maryland court of record could suffer a qui tam forfeiture of two thousand pounds of tobacco if he did not deliver a legible bill of costs recovered from the defendant. ${ }^{269}$ Virginia law imposed a qui tam forfeiture on a court clerk who removed official records and papers from the county. ${ }^{270}$ A New Hampshire clerk of court could be sued by a qui tam informer for failing to deliver to the sheriff and the county treasurer an attested list of fines and forfeitures imposed. ${ }^{271}$

Qui tam legislation also enforced a smorgasbord of other duties relating to judicial administration and the integrity of the legal system. In order to prevent malicious prosecutions by information, a qui tam informer could col-

266 See An Act to Erect and Establish Courts in the Several Counties in This Colony for the Trial of Small Causes, and to Repeal the Former Act for That Purpose, in Laws of THE Colony of New Jersey, supra note 235, at 308 (constable's duties in summoning jury venire); $i d$. at 308-09 (constable's duties in executing judgment); id. at 311 (qui tam forfeiture for violating statutory duties).

267 See An Act Regarding the Proceedings and Trials in Civil Actions, Brought Before Justices of the Peace, in Laws of Rhode IsLAND, supra note 221, § 12, at 193-94 (awarding forfeiture of two dollars a month, "one moiety thereof to and for the use of the State, and the other moiety thereof to and for the use of the informer who shall prosecute for the same").

268 See An Act for Rendering Process in Law Less Expensive (1788), in Laws of MassACHUSETTS, supra note 214, ch. 67, at 126 (awarding forfeiture of $£ 50-500$ for neglect and $£ 500-1000$ for destruction or concealment, "one half to the Commonwealth \& the other half to him or them, who shall sue for the same"). An earlier statute on the same subject imposed different deadlines and smaller forfeitures, but was also enforceable through qui tam litigation. An Act for Rendering Process in Law Less Expensive, in Acts Of MAssachuSETTS, supra note 236 , ch. 43 , at 110 (forfeiture of $£ 50$ for former justice of the peace who delayed six months in lodging records, or for estate executor or administrator who delayed three months, or $£ 100$ for destroying, defacing, or concealing records of deceased justice, "one half thereof to the use of him or them, who shall sue for the same").

269 See Herty, Laws of Maryland, supra note 220, at 91.

270 See An Act Respecting Clerks, supra note 259, § IV, at 101-02 (forfeiture for removing papers and records); id. §VI, at 102 ("All the penalties by this Act imposed, shall be prosecuted for, and recovered by bill, plaint, or information, in any Court of Record, one moiety to the use of the Informer, and the other moiety to the use of the Commonwealth.”).

271 See An Act Prescribing the Duty and Regulating the Office of Sheriff, supra note 231, at 609-10. 
lect a forfeiture if the Attorney General of colonial New Jersey prosecuted someone for a misdemeanor without presentment by a grand jury or an information supported by an order signed by the governor. ${ }^{272}$ The judges of a Virginia county or corporation court could incur a qui tam forfeiture if they failed to maintain a sufficient prison, pillory, and stocks, ${ }^{273}$ failed to make timely nominations to fill a vacancy in the office of coroner, ${ }^{274}$ or if the justices in certain counties failed to provide facilities and equipment needed for hemp inspection. ${ }^{275}$ Maryland judges were obliged to maintain a set of standard English weights and measures, subject to enforcement by qui tam litigation. ${ }^{276}$ Judges in Rhode Island, Connecticut, and New Jersey could face qui tam actions for performing clandestine weddings. ${ }^{277}$ A justice of the peace in South Carolina could incur a forfeiture for failing to administer certain oaths. ${ }^{278}$ Virginia followed the English precedent of permitting a qui tam action against a juror who accepted a bribe. ${ }^{279}$ Statutes in South Carolina, New Jersey, Virginia, and Maryland used qui tam monitoring to restrict

272 See An Act for Preventing Malicious Prosecutions by Informations, in LAws OF NEw Jersey, supra note 263, ch. XLIV, at 27.

273 See An Act Concerning Inferior Courts, supra note 258, § XIII, at 92.

274 See An Act Concerning Coroners, supra note 260, ch. LXXXI, § II, at 131-32.

275 See An Act to Regulate the Inspection of Hemp (1790), in Acts of Virginia, supra note 258 , ch. LIV, § VI, at 59 (giving "one moiety to the prosecutor").

276 See Herty, Laws of Maryland, supra note 220, at 491.

277 See An Act to Prevent Clandestine Marriages, in Laws of Rhode IsLand, supra note 221, $\S 9$, at 485 (imposing forfeiture for judge or minister performing wedding "without due lawful publication"); An Act for Regulating and Orderly Celebrating of Marriages; and for Preventing and Punishing Incestuous and Other Unlawful Marriages, in Laws OF CoNNECTiCUT, supra note 233, $\S 3$, at 286 (subjecting magistrate or minister to forfeiture for performing marriage without prior publication and consent of parents and guardians for those subject to care and control); An Act to Prevent Clandestine Marriages, in Астs оF THe Province of New Jersey, supra note 250, at 79-80 (imposing forfeiture by minister or justice of the peace who marries people without a license or publication, half to the crown, "the other half thereof to the Parents or Guardians of such Person who shall be so joyned in marriage as aforesaid, or to such other Person or Persons who shall prosecute the same to Effect"). A similar forfeiture by Massachusetts judges could be enforced by the county treasurer or by a parent or guardian with responsibility for one of the parties. See An Act for the Orderly Solemnization of Marriages (1786), in Laws of MassachusetTs, supra note 214, ch. 3, at 9 .

278 See An Act for Making Aliens Free of This Part of the Province, in 2 Statutes of South Carolina, supra note 220, at 251-53.

279 See An Act Concerning Grand Juries, Petit Juries, and Venir (1792), in Acts of VIrgINIA, supra note 258, ch. LXXIII, § XIX, at 108; see also An Act Against Such as Shall Procure or Commit Wilful Perjury, and Against Embracery (1789), in Acts OF VIRGinIA, supra note 258, ch. XLVIII, § III, at 52; see also supra note 198 and accompanying text. 
judges, sheriffs, and clerks from pleading as attorneys. ${ }^{280}$ A New Jersey statute used qui tam monitoring to limit the fees attorneys charged. ${ }^{281}$

\section{d. Qui Tam Monitoring of Inspection and Regulatory Regimes}

Our review of English law showed use of qui tam statutes to police regulatory regimes, enforcing obligations of officials who regulated cloth or guild officials who assayed precious metals. ${ }^{282}$ The practice carried over to the new world, where American governments set up regulatory regimes enforceable by qui tam bounties directed at both government officials and regulated parties. A 1715 Maryland statute used qui tam informers to enforce regulations for "hogsheads" (barrels) of tobacco. ${ }^{283}$ The legislation recited difficulties experienced in regulating tobacco merchants, including a conclusion that earlier laws had "in great measure proved ineffectual, either for want of laying sufficient Penalties upon the Offenders, or of proper Methods to inflict them."284 Under the new legislation, any person who suspected that tobacco had been packed in oversized hogsheads could "call to his Assistance any Justice of the Peace, Sheriff, Vestryman, or Church-Warden" to enter a building or ship for the purpose of seizing and marking the questionable barrels. $^{285}$ If examination showed that a hogshead exceeded statutory size requirements, the officer could "condemn the same to the Use of such Informer, who shall thereupon be immediately vested with the Property

280 See An Act for Regulating Attorney's [sic] at Law Within This Province (1694), in Acts of the Province of New Jersey, supra note 250, ch. VI, at 343 (forfeiture for justice of the peace, sheriff, clerk, and others pleading as attorney in courts of province unless a party); An Act for Establishing County and Precinct Courts, in 7 Statutes of South CaroLINA, supra note 220, § VII, at 168; An Act Concerning Counsel and Attornies at Law (1792), in Acts of VIRGInIA, supra note 258, ch. LXXI, § XI, at 104 (forfeiture for justice of the peace, sheriff, or clerk pleading as attorney in court of the county, except as general attorney for nonresident); Herty, LAws of MARYLAND, supra note 220, at 51 (forfeiture of 3000 pounds of tobacco if the magistrate, sheriff, or clerk pleads as an attorney in the court where the person holds office).

281 See For the Better Enforcing the Observation of the Above Recited Ordinance (An Act Enforcing the Observation of the Ordinance for Establishing Fees Within This Province), in LAws of New Jersey, supra note 263, ch. LXVI, at 55.

282 See supra notes 167-70, 199 and accompanying text.

283 An Act Ascertaining the Gauge and Tare of Tobacco Hogsheads; and to Prevent Cropping and Defacing Tobacco Taken on Board Ships or Vessels upon Freight; and for Laying Impositions on Tobacco by the Hogshead, for the Support of Government; and for Encouraging Settlements in This Province, by Ascertaining the Manner of Paying the Alienations, Fines, and Quit Rents, to the Lord Proprietory of This Province, on the Conditions Therein Mentioned (1715), in Acts of MARYLAND, supra note 220, at 87, 168.

$284 I d$.

285 Id. The statute provided that the staves could not exceed forty-eight inches in length, that the head could not exceed thirty-two inches in diameter, and that the bulge could not exceed thirty-seven inches in diameter. Id. A later section of the statute indicated that duties were charged per hogshead of tobacco, which might suggest a motive for using oversized barrels. Id. at 170-71. 
thereof."286 An informer who actually saw a suspicious hogshead (rather than just learning of one in a concealed location) could immediately seize and mark it on his own initiative before "giv[ing] Information to some Justice, or other Officer," who would then go to examine the barrel. ${ }^{287}$ A justice of the peace or other officer who refused or delayed performance of statutory duties would forfeit ten shillings per hogshead to the use of the informer. ${ }^{288}$

New Hampshire used qui tam regulation to monitor the integrity of weights and measures used by local merchants. The selectmen of a town would forfeit $\$ 100$, half "for the use of the person who shall sue for the same," if they did not procure a set of standard weights, measures, and a scale beam as required by law. ${ }^{289}$ The person selected as sealer of weights and measures would forfeit $\$ 50$ for failing to notify inhabitants to bring or send their scale beams, steelyards, weights, and measures for inspection, and \$20 if he neglected some other duty under the act, "one half for the prosecutor." 290 If a person refused to have his weights and measures approved, there was a potential forfeiture to be split between the sealer and the poor of the town. ${ }^{291}$ However, a qui tam action could be brought against a merchant who sold merchandise using unapproved weights and measures, or using sealed weights and measures that proved unjust, one moiety for the poor of the town "the other moiety to the informer who shall prosecute the same."292

A late eighteenth-century Delaware statute used qui tam monitoring to reinforce a system of health inspections in state ports. ${ }^{293}$ The master or commander of a ship carrying more than forty persons, or carrying an infectious passenger, or coming from an infected port would forfeit $\$ 1000$ if he landed without a permit from a doctor appointed to make inquiries. ${ }^{294}$ A smaller $\$ 100$ forfeiture applied if he concealed the existence of a sick passenger or material information about sickness during the voyage. ${ }^{295}$ If the doctor denied a landing permit, the ship could nevertheless try to convince other

$286 I d$. at 168-69. The judgment of the officer was final, and the tobacco was to be released and the mark struck out if the hogshead did not violate the statute. Id. at 169 .

287 Id. at 169.

288 Id. The informer also had a cause of action against anyone who altered or removed a marked hogshead before it could be examined by an officer. Id. Another provision permitted a qui tam forfeiture by any person who sold a hogshead of tobacco that did not have the weight marked on it. Id. at 169-70.

289 An Act Regulating Scale Beams, Steelyards, Weights and Measures (1797), in 6 Laws of New Hampshire, supra note 219, ch. 21, at 446.

$290 I d$.

291 Id. at 445.

$292 I d$. at 445-46.

293 See An Act to Prevent Infectious Diseases Being Brought into This State, and for Other Purposes (1797), in Laws of the State of Delaware: To the Year of Our Lord, One Thousand Eight Hundred and Twenty Nine Inclusive 298 (R. Porter \& Son 1829) [hereinafter LAwS OF DELAWARE].

294 Id. $\$ 1$.

$295 I d . \$ 2$. 
local officials to allow landing of sick passengers under conditions that would not endanger public health. ${ }^{296}$ The doctor was also instructed to inspect the ship for compliance with statutory standards regarding the adequacy of supplies and accommodations for passengers. ${ }^{297}$ A forfeiture of $\$ 50$ applied if the doctor failed to report violations to a local judge. ${ }^{298}$ All of the fines and penalties under the statute were to be divided, with one moiety going to the poor of the county "and the other moiety thereof to the use of him or her who will sue for the same." 299

Many other early American statutes used qui tam litigation to reinforce inspection regimes. New Hampshire's system for inspecting and branding pot ash and pearl ash exported from the state included a number of potential forfeitures by regulated parties, enforceable by qui tam informers, as well as one applicable to an inspector who delayed more than three hours in performing a requested inspection. ${ }^{300}$ A New Hampshire naval officer, responsible for monitoring shipping at the state's ports, could be sued by a qui tam informer for neglecting functions imposed by state law. ${ }^{301}$ A North Carolina naval officer could face qui tam forfeitures for allowing a ship to leave port without a certificate of inspection or for refusing to provide a certificate that the master or commander of the vessel had taken an oath required by law. ${ }^{302}$

\section{$296 \quad I d . \S 3$. \\ 297 Id. § 5, at 299. \\ 298 Id.}

$299 I d . \S 8$, at 299-300. A supplementary statute enacted later may have eliminated the provision for qui tam enforcement. The latter statute provided that all forfeitures in either statute were to be sued for in the name of the state and instructed that suits were to be brought, depending on the location, by the physicians appointed to perform inspections, by specified municipal officials, or by a trustee of the poor. See A Supplement to the Act, Entitled, "An Act to Prevent Infectious Diseases Being Brought into This State and for Other Purposes" (1799), in Laws of Delaware, supra note 293, §9, at 303 . A colonial Georgia statute with similar purposes provided for qui tam actions against various private individuals responsible for a ship who did not truthfully answer questions about the health status of those on board. See An Act to Amend an Act Intituled an Act to Prevent the Bringing into and Spreading of Malignant and Contagious Distempers in the Province; to Oblige Masters or Commanders of Vessels Going out of Any Port Within the Same First to Produce a Passport from the Governour or Commander in Chief; to 'Prevent the Harbouring of Sick Sailors and Others; and for the Regulating and Well Ordering of the Lazaretto upon the Island of Tybee (1770), in 19 The Colonial Records of the State of Georgia: Statutes, Colonial and Revolutionary 1768 to 1773, at 156-60 (Allen D. Candler ed., 1970) [hereinafter Statutes of Georgia].

300 See An Act for the Inspection of Pat and Pearl Ashes (1791), in 5 Laws OF New HAMPSHIRE, supra note 219, ch. 40, at 825 ("[An inspector who shall] unreasonably refuse neglect or delay to proceed to such examination and inspection for the space of three hours ... shall for such offence forfeit the sum of twenty shillings to any person who shall sue for the same.").

301 See An Act for the Regulation of Navigation and Commerce (1785), in 5 Laws of New Hampshire, supra note 219, ch. 8, at 78-80.

302 See An Act to Prevent the Exportation of Unmerchantable Commodities (1784), in Laws of North Carolina, supra note 200, ch. XXVI, §§ VI-VIII, at 496 [hereinafter An Act to Prevent the Exportation of Unmerchantable Commodities]. 
A Georgia inspector could incur a qui tam forfeiture if he intentionally and inaccurately certified that hemp or flax was "Clean made \& Merchantable" or that flour was "Merchantable."303 A Maryland tobacco inspector faced a qui tam forfeiture if he did not burn unmerchantable tobacco, but instead allowed it to be carried away from the inspection site. ${ }^{304}$ Massachusetts provided for local inspection of nails, with forfeitures applicable to nail sellers as well as forfeitures by nail inspectors for neglect or fraud in the performance of their duties. ${ }^{305}$ New Hampshire cullers and surveyors, who inspected wood products prior to shipment, could be sued qui tam for fraud or deceit. ${ }^{306}$ A Connecticut statute for inspection of beef, pork, and other products provided qui tam forfeitures for private exporters, as well as for an inspector who gave a "false certificate" of inspection. ${ }^{307}$ In North Carolina, an inspector was subject to qui tam prosecution for branding empty barrels or lending his inspector's brand to someone else. ${ }^{308}$ Merchants in Rhode Island could be sued by qui tam prosecutors if they sold casks of lime that did not display an inspector's brand or if they employed counterfeit brands or reused casks previously branded, and an inspector could likewise be sued for branding lime in violation of statutory requirements. ${ }^{309}$ In South Carolina, a

303 An Act for Encouraging the Cultivation of Hemp Flax and Wheat and for Regulating the Inspection of Hemp Flax and Wheat Flour (1768), in 19 Statutes of Georgia, supra note 299, at 92-93.

304 See Herty, Laws of Maryland, supra note 220, at 505.

305 See An Act for Regulating the Manufacture of Nails, Made for Sale or Exportation Within This Commonwealth and Repealing All Laws Heretofore Made for That Purpose (1790), in LAws of Massachusetts, supra note 214, ch. 36, at 445-46 (forfeiture of £4 for "any neglect or fraud in inspecting Nails" or marking cask "which they have not actually and thoroughly inspected" to be recovered "by any person who will sue and prosecute therefore").

306 See An Act for the Admeasurement of Boards and for Regulating the Sale of Shingles Clapboards Hoops and Staves and for Other Purposes Therein Mentioned (1785), in 5 Laws of New Hampshire, supra note 219, ch. 4, at 73.

307 An Act for the Inspection of Provisions and Other Articles of Commerce, in Laws of Connecticut, supra note 233, § 12, at 244 (forfeiture for exporter who does not comply with requirements for inspection, packing, and branding, "one Half to the Person who shall prosecute or sue for the same"); id. $\S 13$, at 244 (forfeiture for violating rules on tobacco exports, "one Half to the Prosecutor"); $i d$. $\$ \$ 18-19$, at 245 (forfeiture for "false Certificate" by inspector, "one Half to the Person who shall prosecute or sue for the same”).

308 See An Act to Prevent the Exportation of Unmerchantable Commodities, supra note 302, $\S$ XXI, at 499. There was also a forfeiture for a person who arranged for branding by someone other than the inspector or his assistant. Id.; see also An Act the Better to Regulate the Inspection of Tobacco in This State, in Laws of North Carolina, supra note 200, ch. XVI, $\S \mathrm{V}$, at 671 (naval officer who neglects to certify mark and quality of each hogshead of tobacco forfeits $£ 50$ "to the Use of any Person suing for the same").

309 See An Act Regulating the Assize of Lime-Casks, and the Inspection of Lime, in Laws OF RHODE IsLAND, supra note 221, \$§ 3-5, at 517-18 (\$ 3 "moiety to the complainant or informer"; $\$ 4$ recoverable by indictment or other due process, "one moiety thereof to the prosecutor"; $\S 5$ "one moiety to and for the use of the prosecutor," other moiety to the inspector). 
receiver could face a qui tam forfeiture for licensing a public house or retailer of liquor without the approval of specified individuals trusted by the legislature. ${ }^{310}$

\section{e. Qui Tam Monitoring of Quasi-Public Functions}

In addition to use of qui tam legislation to monitor decentralized conduct by public officials, it may be relevant to highlight qui tam statutes directed at persons performing what could be considered quasi-public functions. For instance, statutes sometimes imposed legal duties on church officials. One colonial New Jersey statute required officials in each parish, church, chapel, or meeting house to read the statute once a year after worship services. ${ }^{311}$ The vestrymen of a Maryland parish could suffer a qui tam forfeiture if they failed to inspect the parish library twice a year. ${ }^{312}$

Qui tam legislation was sometimes used to enforce duties of persons liable for militia service. An early New Jersey statute for organizing the militia imposed certain forfeitures enforceable by militia officers. For instance, militia leaders could collect penalties from those who did not appear for semiannual training, who appeared without the required weaponry, or who refused an appointment to serve as a corporal or sergeant. ${ }^{313}$ However, the statute included qui tam forfeitures for individuals neglecting to stand watch in a time of public danger or leaving a post before being relieved by someone else. ${ }^{314}$ A Georgia law from 1770 required male militia members to bring guns or pistols when they attended worship services, subject to a penalty of ten shillings, "half to him or them that shall give information thereof." 315 Church leaders were required to periodically inquire into compliance with

310 See An Additional Act to an Act Entitled for the Better Regulating Taverns and Punch-Houses, in 3 Statutes of South Carolina, supra note 220, § 7, at 581-85.

311 See An Act to Prevent the Destroying and Murdering of Bastard Children, in Acts of the Province of New Jersey, supra note 250, ch. LXXIII, § 3, at 274 (requiring public reading of act annually "by the Clerk of [each] Parish Church, Chappel or Meeting, immediately after Divine Service, under the Penalty of Twenty Shillings for every Omission and Neglect therein; to be recovered with Costs, by the Informer").

312 See An Act for Securing the Parochial Libraries of This Province (1723), in Acts of MARYLAND, supra note 220, at 30 (imposing forfeiture if a vestry did not inspect libraries twice a year, one moiety to crown, "the other Moiety to the Informer, or him or them that shall sue for the same”).

313 See An Act for Settling the Militia of This Province, in Laws of New Jersey, supra note 263 , ch. XL, at 17-19.

314 See id. at 18-19 (awarding "one half to the informer who shall prosecute the same to effect" and the other half to the crown). A very similar statute replicating many of the same provisions was enacted a few years later. See An Act for the Settling the Militia of This Province, in LAws of New Jersey, supra note 263, at 139-42.

315 An Act for the Better Security of the Inhabitants by Obliging the Male White Persons to Carry Fire Arms to Places of Public Worship (1770), in 19 Statutes of Georgia, supra note $299, \S 1$, at 138 . 
the statute, and could face a qui tam forfeiture if they did not give information against a violator. ${ }^{316}$

Qui tam monitoring also facilitated regulation of quasi-public functions performed by ferry operators. A colonial New Jersey statute authorized the governor to grant an exclusive license to operate a ferry over the Delaware River between Burlington and New Bristol, and established fees that could be charged for ferry service. ${ }^{317}$ The ferry operator could be sued by a qui tam informer for failing to keep sufficient boats or failing to duly attend to ferry service. ${ }^{318}$ A Rhode Island statute permitted a qui tam action against a ferry operator who refused carriage to someone tendering payment, failed to keep his boat in readiness, or allowed his boat to be absent from the ferry location. ${ }^{319}$ A Connecticut statute allowed qui tam suits against ferry operators who did not diligently attend to ferry operations during specified hours, or who charged higher fares than authorized by statute. ${ }^{320}$ South Carolina ferry operators could be sued for neglect or for carrying persons in violation of the statute. ${ }^{321}$

\section{Conflict of Interest Rules: Countering Incentives for Resistance}

As in English law, early American governments sometimes used qui tam legislation to counter conflicts of interest that might result in noncompliance with statutory directives. The Maryland legislature, for instance, required Baltimore and Georgetown to appoint inspectors of potash and pearlash. ${ }^{322}$ The inspectors were not allowed to sell or trade in potash or pearlash, subject to a $£ 100$ penalty, half allocated to the use of the person suing for it. ${ }^{323}$ North Carolina provided for qui tam enforcement of a rule preventing an inspector from purchasing cullings or items that did not pass inspection. ${ }^{324}$ A Maryland county surveyor could suffer a qui tam forfeiture if he secretly

316 Id. $\$ 2$, at 138-39. The congregant could also face a qui tam forfeiture for refusing to cooperate with an inquiry by church leaders under the statute. Id. $\S 3$, at 139 .

317 See An Act for Establishing a Ferry from the Town of Burlington, to the Town of New-Bristol, in Laws of New Jersey, supra note 263, at 34.

318 See id.

319 See An Act Regulating Ferries, in Laws of RHOdE IsLAND, supra note 221, § 7, at 573 (forfeiture for neglecting to keep boat in readiness or refusing to transport person applying for passage); $i d . \S 9$, at 573-74 (forfeiture for allowing boat to be absent from ferry).

320 See An Act for Regulating Ferries, in Laws of Connecticut, supra note 233, § 4, at 196 ("[O]ne Half to the Informer or Complainant, who shall prosecute the same."); $i d$. $\S 13$, at 197 ("[O]ne Moiety to the Treasurer of the State and the other Moiety to be divided between the Informer and the Person injured.").

321 See An Act for Establishing Five Ferries; One over Winyaw River, Two over Santee River, One over Sampit Creek, and One over Cooper River, in Statutes of South CaroLINA, supra note 220 , $\S 5,8$, at 71-72.

322 See Herty, Laws of Maryland, supra note 220, at 431-32.

323 See id.

324 See An Act to Prevent the Exportation of Unmerchantable Commodities, in Laws of North Carolina, supra note 200, ch. XXVI, § XXII, at 499. 
purchased land within the county, personally or through an agent. ${ }^{325}$ Statutes regulating fraudulent conduct by inspectors are also relevant here, ${ }^{326}$ since inspection fraud would often be motivated by financial considerations.

Use of qui tam regulation to counter conflicts of interest continued well after the framing period. An 1819 Delaware statute provided that a sheriff or constable responsible for selling goods pursuant to law could not bid on the sale items directly or through an agent. ${ }^{327}$ An 1829 statute regulated trustees running the local "poor house." Their responsibility for expenditure of public funds created opportunities for self-dealing. To address the problem, the statute provided that no trustee of the poor "shall directly or indirectly furnish any article for the poor" and "all purchases shall be made from persons not Trustees." 328 A violation made the trustee liable to pay "fifty dollars to any person, who will sue for the same." ${ }^{329}$

\section{Bolstering Public Confidence in Government}

A third reason for using qui tam legislation to regulate public officials is to bolster public confidence in the lawful performance of important government functions. For instance, the secretary of the Maryland assembly was required to record acts of the assembly in an official legislative book and affix his seal. ${ }^{330}$ A secretary neglecting to do so could forfeit ten thousand pounds of tobacco, half to the use of the informer. ${ }^{331}$ This was not decentralized conduct that would be difficult for the central government to monitor. Nor did the secretary of the assembly operate under a continuing conflict of interest that would impede performance of this duty. The most plausible rationale for using qui tam legislation in this context was to create a high likelihood that a particularly important government function would be regularly and scrupulously performed, regardless of the circumstances. Similar considerations help explain extensive use of qui tam statutes to monitor duties of officials in connection with elections and the collection and expenditure of tax funds.

\section{a. Elections}

One critical function of republican government is to conduct elections that allow peaceful reallocation of political authority. If the public comes to doubt the integrity of the election process, the legitimacy of government authority will be called into question. Early American state governments

325 See Herty, Laws of Maryland, supra note 220, II 7-8, at 497.

326 See, e.g., supra notes 303, 306-07 and accompanying text.

327 See A Supplement to the Act Entitled "An Act for the More Easy and Speedy Recovery of Small Debts,” in Laws of Delaware, supra note 293, § 8, at 214.

328 An Act to Consolidate and Amend the Laws for the Relief of the Poor (1829), in Laws of Delaware, supra note 293, § 18, at 445.

$329 I d$.

330 See Herty, Laws of Maryland, supra note 220, at 16.

331 See id. 
often used qui tam regulation to supervise persons conducting or participating in elections. Such legislation provided a public check on the electoral process, increasing the likelihood that election-related duties would be faithfully performed and reducing opportunities for public officials to corrupt the integrity of the process.

England had used qui tam legislation to enforce statutory disqualifications for service in Parliament. ${ }^{332}$ Similar laws can be found in the early American states. Colonial New Jersey provided that those disabled from serving in the English House of Commons by reason of an office, pension, or salary from the government were also disabled from serving in the state General Assembly. ${ }^{333}$ A person who served in the state House of Representatives notwithstanding the statutory disability would forfeit $£ 50$ to be recovered "by such Person as shall sue for the same."334 A North Carolina candidate for office could face a qui tam forfeiture of $£ 500$ if he had aided and abetted the British during the Revolutionary War. ${ }^{335}$

Several states used qui tam monitoring to discourage election fraud or misconduct. Connecticut allowed qui tam prosecutions for vote buying. ${ }^{336} \mathrm{~A}$ Pennsylvania election judge, inspector, or clerk who committed willful fraud in connection with an election could forfeit $£ 100$ to a qui tam litigant. ${ }^{337}$ Qui tam informers ensured the integrity of New Hampshire town meetings, collecting a forfeiture from the moderator if he counted two votes from the same person, added to or subtracted from the lawful vote total, or accepted a

332 See supra notes 196-97 and accompanying text.

333 See An Act for Securing the Freedom of Assemblies (1730), in Laws of The Colony OF New JERSEY, supra note 235, at 399.

$334 I d$. at 400.

335 See An Act to Amend an Act, Passed at Newbern, in November, One Thousand Seven Hundred and Eighty-four, Entitled, An Act to Describe and Ascertain Such Persons Who Owed Allegiance to This State, and to Impose Certain Disqualifications on Certain Persons Therein Described (1785), in Laws of North Carolina, supra note 200, ch. XI, $\S \S \mathrm{I}-\mathrm{II}$, at 555 .

336 See An Act for Regulating the Election of the Governor, Lieutenant Governor, Assistants, in Laws of Connecticut, supra note 233, § 13, at 153 (imposing forfeiture of \$17 for "giving, offering, accepting or receiving" a gift, fee, or reward for voting in General Assembly election, "one half to him or them that shall sue for and prosecute the same to Effect, and the other half to the Treasury of the Town"). North Carolina imposed a forfeiture for vote buying. However, unlike other sections of the statute, this provision did not specify qui tam actions as a method of enforcement. See An Act Directing the Method of Electing Members of the General Assembly, and Other Purposes (1777), in Laws of North Carolina, supra note 200, ch. IV, § XII, at 320-21 (imposing $£ 500$ forfeiture for giving money, gift, gratuity, or reward for votes of electors in General Assembly election). 337 An Act to Regulate the General Elections of This Commonwealth and to Prevent Frauds Therein (1785), in 12 The Statutes at Large of Pennsylvania from 1682 to 1801, ch. MCLXXV, § XXV, at 48-49 (James T. Mitchell \& Henry Flanders eds., 1906) [hereinafter Statutes of Pennsylvania] ("[E]very specific fine and forfeiture by this act declared and imposed on any person (not otherwise directed) who shall become liable to the same, shall be recovered by actions of debt founded on this act, to any person who shall sue for the same in the court of common pleas of the county or in the supreme court, or by information or indictment to the use of the informer or prosecutor.”). 
proxy vote that was not personally delivered. ${ }^{338}$ In Rhode Island, the moderator of a meeting could be sued if he failed to follow statutory procedures concerning challenges to the eligibility of a voter ${ }^{339}$ or proxy voter. ${ }^{340}$

The fraud suppression statutes were often accompanied by more general qui tam regulation of the electoral process. ${ }^{341}$ A Virginia sheriff or mayor could face litigation for a number of election-related offenses, from refusing to conduct a poll when required, to falsely certifying returns, to neglecting to deliver poll books to the clerk of court. ${ }^{342}$ A North Carolina sheriff could be sued by a qui tam informer for neglecting or refusing to prepare election returns or otherwise violating election procedures. ${ }^{343}$ When Kentucky was organized as a state separate from Virginia, officers conducting the elections could be sued "by any person" for failing to perform election-related duties. ${ }^{344}$ In New Hampshire, a constable who failed to provide notice to a person elected to town office could be sued for thirty shillings by "any inhabitant of this State who will sue for the same," half to the use of the town "and the other half to the use of the prosecutor." 345 Sheriffs and town clerks could suffer qui tam forfeitures for neglecting to make timely election returns. ${ }^{346}$ Selectmen who neglected to schedule a meeting for electoral purposes would forfeit $£ 10$ to a qui tam informer. ${ }^{347}$ South Carolina justices of the peace and other officials could also face qui tam forfeitures for neglecting duties under the election laws. ${ }^{348}$

338 An Act to Prevent Undue Influence, and Fraud in Town Meetings, and in the Choice of Town and State Officers (1799), in 6 LAws of New HAMPshire, supra note 219, at 568-69.

339 An Act Regulating the Manner of Admitting Freemen, and Directing the Method of Electing Officers in This State (1798), in Laws of Rhode Island, supra note 221, $\$ 10$, at 120-21; see id. $\S 12$, at 122 (directing forfeitures be recovered "half to and for the use of him who shall inform and sue for the same").

340 See id. $\S 12$, at 122 ("And that all the aforementioned forfeitures in this act may be recovered by an action in any court of record in this State proper to try the same; one half whereof shall be to and for the use of this State, and the other half to and for the use of him who shall inform and sue for the same.").

341 See, e.g., An Act Regulating the General Election (1826), in Laws of Delaware, supra note $293, \S 16$, at 186 (imposing qui tam forfeiture on a variety of officers for willful neglect or fraud in connection with election-related duties).

342 See An Act Concerning Election of Members of General Assembly (1785), in Acts OF VIRGINIA, supra note 258, ch. XVII, § XVII, at 22 (directing that one-half of the specified forfeitures were payable to "any person who will sue for the same").

343 An Act Directing the Method of Electing Members of the General Assembly, and Other Purposes (1777), in Laws of North Carolina, supra note 200, ch. IV, § XV, at 321.

344 An Act Concerning the Erection of the District of Kentucky into an Independent State (1789), in Acts of VIRGINIA, supra note 258, ch. LIII, §§ II-III, at 55.

345 An Act for Regulating Towns, supra note 222, ch. 41, at 590.

346 See An Act for Laying a Fine on Delinquent Sheriffs and Town Clerks (1786), in 5 LAws of New Hampshire, supra note 219, ch. 9, at 112-13.

347 See An Act for Regulating Towns, supra note 222, ch. 41, at 593.

348 See An Act to Ascertain the Manner and Form of Electing Members to Represent the Inhabitants of This Province in the Commons House of Assembly, and to Appoint Who 


\section{b. Taxing and Spending}

Just as the public tends to be very concerned with the integrity of the election process, citizens also have a heightened interest in collection of taxes and expenditure of public funds. Many eighteenth-century American governments found qui tam legislation useful for enforcing duties related to taxing and spending. In 1716, for example, the New Jersey General Assembly responded to a report from the provincial treasurer indicating that several counties had been in arrears on tax payments since 1708. ${ }^{349}$ The legislature appointed persons in each county to inspect the tax assessment rolls to determine whether deficiencies were attributable to the death, removal, or insolvency of taxpayers. ${ }^{350} \mathrm{~A}$ tax collector or administrator of the collector's estate who neglected to make tax assessment records available to inspectors could forfeit $£ 50$ to "any one that will Sue for the Same to Effect the one Half To be to the Prosecutor and the other half for the support of the Government."351

North Carolina property tax legislation invoked the goal of promoting transparency and accountability, declaring it "just and right that the Body of the People on whom Taxes are laid, should know to what Purposes the Monies arising therefrom are applied and appropriated." 352 Under the statute, a county clerk could face a qui tam action for neglecting to post public lists of taxable property and of persons the tax collector deemed insolvent. ${ }^{353}$ The requirement of publication was designed to provide a "Check against fraudulent and deficient Returns of taxable Property, and to prevent improper Allowances for Insolvents." 354 A parallel remedy could be invoked against county commissioners who did not publish an "accurate List of the Taxes levied and collected in such Town, together with a List of each Sum expended by said Commissioners, and to whom paid, and for what Purpose." 355

Legislatures often deployed qui tam informers to ensure maintenance and oversight of tax records. In Maryland, county commissioners were

Shall be Deemed and Adjudged Capable of Choosing or Being Chosen Members of the Said House, in Statutes of South Carolina, supra note 220, $\$ 13,16,20$, at 441-48.

349 An Act to Enable Some Persons in Every County of This Province to Inspect the Rolls of All the Assessments in the Said County, which Lye in the Hands of the Collectors Since the Year One Thousand Seven Hundred and Eight, and also Examine the Acco[un]ts of the Collectors and See What Deficiencies of Persons Dead, Removed, or Insolvent Remain Unpaid, and Report the Same to This House at the Next Meeting of This Assembly, in Laws of the Colony of New Jersey, supra note 235, at 393.

$350 \quad I d$. at 394.

351 Id.

352 An Act to Compel Certain Officers Therein Mentioned to Publish the Application of the Public Monies, and Allowances for Insolvents (1786), in Laws of North Carolina, supra note 200 , at 587.

$353 I d . \S 2$, at 588 (forfeiture by clerk neglecting or refusing to perform duties imposed by act "to any Person who shall sue for the same").

$354 I d$.

$355 I d . \S 5$. 
empowered to make levies of tobacco to defray public charges. ${ }^{356}$ The county clerk was required to annually transmit an account showing the tobacco levied and its disposition, enforceable by a forfeiture of one thousand pounds of tobacco, "[h]alf to the Informer, or him or them that will sue for the same." 357 A North Carolina naval officer could be sued by a qui tam informer for allowing a ship to leave port without proof of tax payment. ${ }^{358}$ New Jersey tax collectors could forfeit $£ 50$ for failing to pay over money collected, along with a list of assessments. ${ }^{359}$ A New Hampshire statute authorized the selectmen of New London to collect a tax from nonresident owners of land to use for road repairs, and provided for qui tam enforcement if the selectmen neglected to account within four years for the appropriation and expenditure of the funds. ${ }^{360}$ Similar statutes enforced a duty to account imposed on selectmen of other New Hampshire towns. ${ }^{361}$ A 1740 New Jersey statute noted that only certain residents of Essex county had been taxed for repair of the Newark court house and jail, and imposed duties on a number

356 An Act Impowering the Commissioners of the County Courts to Levy and Raise Tobacco, to Defray the Necessary Charges of Their Counties and Parishes (1704), in AcTs OF MARYLAND, supra note 220, at 37.

357 Id; see also Herty, Laws of Maryland, supra note 220, at 337.

358 See An Act for Facilitating the Navigation, and Regulating the Pilotage of the Several Ports of This State (1783), in Laws of North Carolina, supra note 200, ch. XX, $\$ \S ~ X V$, at 465 (forfeiture for naval officer who allowed ship to clear without master producing certificate of payment from tax receiver), XXII at 466 ("[E] ach and every Fine imposed by this Act, shall be recovered by Action of Debt in any Court of Record having Cognizance thereof, one Half to the Person suing for the same.”).

359 See An Act for the Support of the Government of His Majesty's Province of New Jersey for Five Years, to Commence from the Twenty Third Day of September, One Thousand Seven Hundred and Twenty, and to End the Twenty Third Day of September, One Thousand Seven Hundred Twenty and Five, in Laws of New Jersey, supra note 263, at 131-32.

360 See An Act to Enable the Select Men of New London in the County of Hillsborough to Assess, Levy and Collect a Tax on All the Lands of Non Resident Proprietors in Said Town of Three Pence Per Acre for the Purpose of Repairing the Public Roads in Said New London (1791), in 5 Laws of New Hampshire, supra note 219, ch. 8, at 546-47.

361 See, e.g., An Act to Impower the Inhabitants of Wendall in the County of Cheshire to Levy a Tax on All of the Lands (Public Rights Excepted) in Said Town for Making, Bridging and Repairing the High-Ways (1791), in 5 LAws of New HampshiRe, supra note 219, ch. 16, at 556 (one-half to the prosecutor and the other half to the use of the County); An Act to Empower the Inhabitants of Dorchester in the County of Grafton to Levy a Tax on All Lands (Publick Lands Excepted) in Said Town for Making and Repairing the High Ways (1791), in 5 Laws of New Hampshire, supra note 219, ch. 21, at 803 (same); An Act to Enable the Selectmen of Campton to Assess \& Cause to Be Collected One Penny Per Acre Annually for Two Years on All the Unimproved Lands in Said Campton (1792), in 5 Laws OF New Hampshire, supra note 219, ch. 18, at 773 ("[O]ne half to the person or persons who shall sue for the same \& the other half to the use of said County."); An Act to Enable the Selectmen of the Town of New Hampton to Assess \& Cause to Be Collected One Penny Per Acre on Each Acre of Land in Said Town Annually, Publick Rights Excepted, for the Term of Three Years from the Passing This Act (1792), in 5 Laws of New Hampshire, supra note 219 , ch. 24, at 780 (same). 
of officers in order to complete the collection effort. ${ }^{362}$ A qui tam provision allowed "any person that will sue" to collect forfeitures from officers neglecting duties imposed by the statute, including assessors, collectors, constables, justices, and specially appointed managers. ${ }^{363}$ South Carolina receivers could be sued for misdirection of public funds. ${ }^{364}$

\section{Early Federal Qui Tam Statutes Directed at Executive Branch Officials}

When members of Congress assembled following ratification of the new Constitution, they faced enforcement problems analogous to those confronted in earlier years by the English Parliament and state legislative assemblies. They had to figure out how to incentivize and monitor executive compliance with congressional directives, even though federal officials would be geographically dispersed throughout a vast territory. Since the new government began its existence encumbered by Revolutionary War debts, Congress needed to provide for that monitoring at a reasonable cost. ${ }^{365}$ To accomplish these objectives, the First and Second Congresses borrowed from the practices of the English Parliament and earlier American legislatures, selectively employing qui tam regulation of executive branch officials alongside provisions for litigation by injured parties and by government officials.

\section{Revenue Officers}

When the House of Representatives opened its doors to the public on April 8, 1789, ${ }^{366}$ James Madison gave a speech highlighting the widely recognized "deficiency in our treasury" and urging an impost on imports to estab-

362 See An Act for Raising of Money for Finishing and Compleating the Goal and CourtHouse, Already Erected at Newark in the County of Essex (1740), in Laws of THE Colony OF New Jersey, supra note 235, at 533-36.

$363 I d$.

364 See An Act to Continue an Act Entituled An Act for Laying an Imposition on Furrs, \&c., and for Appropriating the Same, in 3 Statutes of South Carolina, supra note 220, at 248; An Additional Act to an Act Intituled an Act to Continue an Act Intituled an Act for Laying an Imposition on Furrs, \&c., and for Appropriating the Same, in 2 STAtUtes of South Carolina, supra note 220, at 296.

365 See Letter from Arthur Lee to Tench Coxe (May 12, 1789), in 15 Documentary History of the First Federal Congress of the United States of America 4 March 1789-3 MARch 1791, at 530, 530 (Johns Hopkins Press 2004) [hereinafter DocumentaRY History] ("The augmentation of Offices, will meet with much opposition unless they are demonstrably necessary. For there is much apprehension of alarming the People, with an apparently expensive commencement of the new Government.”). Evan Caminker notes that federal resource constraints helped justify the 1986 congressional decision to reinvigorate qui tam litigation under the False Claims Act. See Caminker, supra note 137, at $350-51$.

366 See New-York Daily Gazette (Apr. 9, 1789), in 10 Documentary History, supra note 365, at 3, 3 ("Yesterday the doors of the House of Representatives of the United States, were thrown open for the admission of the Citizens."). 
lish a national revenue. ${ }^{367}$ Of the first five statutes passed by Congress, three focused on this revenue-raising goal, including one laying duties on imports, ${ }^{368}$ one laying duties on tonnage of ships, ${ }^{369}$ and one establishing a system for collection of those duties. ${ }^{370}$ The Collection Act involved a massive undertaking in which Congress established fifty-nine collection districts in the eleven states that had already ratified the Constitution (all but Rhode Island and North Carolina), ranging from a high of twenty collection districts in Massachusetts, to a low of one district each in New Hampshire, Pennsylvania, and Delaware. ${ }^{371}$ Each district included a port of entry and might also include multiple ports of delivery. ${ }^{372}$ The Act provided for appointment of hundreds of federal customs officers to be stationed throughout the eastern ports of the United States. Busier ports of entry would be served by three lead officials-a collector, a naval officer, and a surveyor-aided by minor functionaries including a deputy collector, inspectors, weighers, measurers, and gaugers. $^{373}$ Less active ports might be assigned only one or two of the higher ranked officials. ${ }^{374}$

The Collection Act imposed a significant number of penalties on masters and commanders of ships and other private individuals, and provided for forfeitures of merchandise, vessels, and other property for violation of statutory requirements. ${ }^{375}$ Congress had a decision to make about enforcement of those penalties. While qui tam legislation had been used in some Anglo-

367 The Congressional Register (Apr. 8, 1789), in 10 Documentary History, supra note 365 , at $4-5$.

368 See An Act for Laying a Duty on Goods, Wares, and Merchandises Imported into the United States, ch. 2, 1 Stat. 24 (1789).

369 See An Act Imposing Duties on Tonnage, ch. 3, 1 Stat. 27 (1789).

370 See An Act to Regulate the Collection of the Duties Imposed by Law on the Tonnage of Ships or Vessels, and on Goods, Wares and Merchandises Imported into the United States, ch. 5, 1 Stat. 29 (1789) [hereinafter Collection Act].

$371 \quad I d . \S 1$.

372 Id. For instance, Portsmouth was the sole port of entry for the district of New Hampshire, and all ships were required to enter and clear there, but from Portsmouth they might move on to ports of delivery established at Newcastle, Dover, and Exeter. Id.

$373 I d$. (officers assigned to each port), $\$ 5$ (duties of collector, naval officer, and surveyor; supervision of inspectors, weighers, measurers, and gaugers), $\$ 6$ (deputy collectors), $\S 15$ (appointment of inspectors).

$374 \quad I d . \S 1$.

$375 I d$. $\$ 11$ (forfeiture for commander of vessel who does not deliver manifests or take oath), $\S 12$ (forfeiture for unloading goods except during the day and with a permit; seizure of goods by customs officer); $i d . \S 15$ (forfeiture of goods removed from wharf without weighing and gauging or without permission of officer); $i d . \S 16$ (forfeiture by master or commander if goods delivered do not agree with manifest); id. $\$ 23$ (forfeiture of packaged goods if inspection shows that they differ from documented entries); id. $§ 24$ (forfeiture of goods concealed to avoid duties); $i d$. $\$ 25$ (forfeiture for concealing or buying goods subject to forfeiture under act); $i d$. $\S 34$ (forfeitures for relanding goods once they have been entered for exportation in order to obtain a drawback of duties); $i d$. § 35 (forfeiture for offering bribe to customs official and penalties for falsely swearing oath); $i d$. $\S 40$ (forfeitures for bringing goods into the United States other than by sea in vessels of at least thirty tons burden). 
American revenue collection regimes, common informers were a controversial method of law enforcement. In a letter to Congressman Goodhue, a Massachusetts merchant expressed hope for a collection system that would operate "without having recourse to the encouragement of a contemptible and infamous host of informers." 376 In a letter to Senator Strong, on the other hand, another Massachusetts merchant passed along an idea from state Comptroller General Leonard Jarvis "that the whole of any forfeiture ought to be given to the informer" as an "inducement to vigilance." 377 James Sullivan, a former judge and future governor of Massachusetts, commented to Congressman Gerry on the need to "eradicate an opinion Established with the body of the people when we were a part of [the] British Empire" that "an Informer against Smuglers was more odious than a theif [sic]." 378 He recommended letters to newspapers throughout the country "to change the public opinion and to make the people veiw [sic] Informers as meritorious." 379

Congress opted against qui tam enforcement of Collection Act penalties directed at private parties, but tried nevertheless to induce disclosure of smuggling and other offenses. Under section 36 of the Collection Act, all penalties were to be sued for "in the name of the United States . . . by the collector of the district where the same accrued, and not otherwise," with the only exception being for "cases of penalty relating to an officer of the customs." 380 Property subject to forfeiture under the Act was to be "seized, libelled and prosecuted as aforesaid." 981 Though only public officials could enforce the duties of regulated parties, the Act offered rewards for information that resulted in a recovery. Penalties and forfeitures, unless otherwise allocated, were to be split between the government and federal customs officers, with one-half going to the United States treasury and one-half divided among the port's collector, naval officer, and surveyor. ${ }^{382}$ However,

376 Letter from Epes Sargent to Benjamin Goodhue (May 26, 1789), in 15 DocumeNTARY History, supra note 365, at 631, 632.

377 See Letter from Samuel Phillips, Jr. to Caleb Strong (June 11, 1789), in 16 DocumeNTARY History, supra note 365, at 749, 750 (noting that the Comptroller General, Leonard Jarvis, believed the increased monitoring provided by the heightened financial incentive would "encrease the revenue more than a share of those forfeitures would add to it"); see also Letter from Leonard Jarvis to Benjamin Goodhue (Aug. 13, 1789), in 16 Documentary History, supra note 365, at 1305, 1305-06 (commenting on the first Collection Act and suggesting need for greater financial inducements for informers and officers; noting that "the Act of informing or seizing may be attended with an Odium not attached to the Act of prosecuting").

378 See Letter from James Sullivan to Elbridge Gerry (June 23, 1789), in 16 DocumeNTARY History, supra note 365, at 843, 844; see also Letter from James Sullivan to Elbridge Gerry (July 25, 1789), in 16 Documentary History, supra note 365, at 1133, 1134 (referring to "the contempt \& abhorrence to informers which has long Existed in the united States").

379 See Letter from James Sullivan to Elbridge Gerry (June 23, 1789), in 16 DocumeNTARY History, supra note 365 , at $843,844$.

380 Collection Act, supra note $370, \S 36$

381 Id.

382 Id. $§ 38$. 
where a recovery occurred "in pursuance of information given to such collector, by any person" other than a naval officer or surveyor, half of the officers' share was "given to the informer." 383 Thus, an informer could not bring suit against private parties for revenue offenses, as would be the case under a qui tam provision, but could furnish information to the local collector-who was authorized to sue-and would receive one-quarter of any resulting recovery.

Though Congress decided against popular enforcement of the Collection Act penalties for private conduct, it did authorize qui tam enforcement of two provisions imposing duties on customs officers. Section 8 of the statute required each collector, naval officer, and surveyor to take an oath "before he enters on the execution of his office." 384 To enforce the oath requirement, Congress provided: "Any collector, naval officer or surveyor, failing herein, shall forfeit and pay two hundred dollars, recoverable with costs in any court having cognizance thereof, to the use of the informer." 385 Section 29 required each collector, naval officer, and surveyor to "cause to be affixed, and constantly kept in some public and conspicuous place of his office, a fair table of the rates of fees, and duties demandable by law." 386 Congress again provided that officers who failed to comply would suffer a qui tam forfeiture of $\$ 100 .{ }^{387}$

Why did Congress authorize qui tam enforcement of two forfeitures directed at customs officials under the Collection Act when it opted not to use qui tam enforcement for other aspects of the legislation? The decision likely flowed from the difficult management challenge created by a large and dispersed federal workforce. Treasury Secretary Alexander Hamilton reflected on this difficulty in a report to Congress eight months after enactment of the legislation. Hamilton suggested creation of an additional layer of bureaucracy-appointment of "an officer in each state or other considerable subdivision of the United States, having the general superintendance of all the officers of the Revenue within such state or subdivision." 388 Not only would this facilitate collection of revenue from remote ports, but it was "in the opinion of the Secretary, essential to a due supervision of the conduct of the particular officers engaged in the collection of the revenues." 389 Hamilton believed it impossible that the need for supervision could be satisfied "by any attention or vigilance of an Individual or Individuals at the Head of the Treasury. Distance, and the multiplicity of avocations, are conclusive bars." 390 The oath requirement of section 8 and the requirement to post a

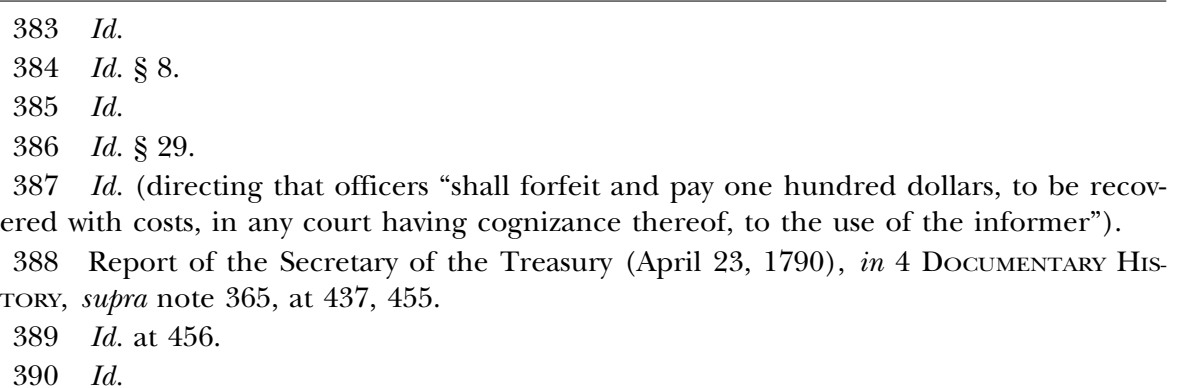


table of rates and fees under section 29 involved the actions of dozens of customs officials scattered throughout the (then eleven) United States. It would be extremely difficult for President Washington or Secretary Hamilton in New York to monitor all of those officials. As in English and early American state law, qui tam provisions allowed Congress to provide for oversight of the legality of executive conduct at minimal cost and without depletion of federal enforcement resources.

Congress chose not to use qui tam enforcement for other duties of customs officers. For instance, in addition to the provision for qui tam suit for failure to post a schedule of rates and fees, section 29 of the Act included a forfeiture of "two hundred dollars . . . for the use of the party grieved" if a customs officer "shall demand, or receive any greater or other fee, compensation or reward, for executing any duty or service required of him by law."391 The distinct enforcement mechanisms for these various penalties makes sense because every overcharge by a customs officer would have an identifiable victim, whereas failing to take an oath and failing to post a table of fees might not produce identifiable harm to anyone in particular. Less clear is why Congress failed to allow qui tam enforcement of section 35, which imposed a forfeiture ranging between 200 and 2000 dollars and disqualification for future office if a customs officer took a bribe or "connive[d] at a false entry of any ship or vessel, or of any goods, wares or merchandise." 392

Congress replaced the initial Collection Act about a year later with a more comprehensive statute including Rhode Island and North Carolina, which had ratified the Constitution in the interim. ${ }^{393}$ The expanded legislation designated sixty-seven collection districts and authorized a correspondingly larger number of federal customs officers. ${ }^{394}$ The qui tam provision

391 Collection Act, supra note 370, § 29.

392 Id. $§ 35$. It could be that Congress did not provide for qui tam enforcement of this anticorruption provision to guard federal officials against the possibility of false accusations of soliciting bribes. In the cases where Congress provided for qui tam enforcement, evidence that the officer had complied with the law would be readily available. If an officer had in fact taken the oath of office, it should be possible to produce either the official who administered the oath or the written certification of compliance required by the statute. $I d . \S 8$ (requiring sealed certificate of administration of oath transmitted to comptroller of the treasury). If an officer had posted a notice of fees and rates to be charged, it should be possible to produce other officers or members of the public who could testify to seeing the notice. Id. \$29. On the other hand, if an informer claimed a federal surveyor in some remote port had demanded a bribe, the litigation could turn into a contest of credibility between two competing witnesses, and Congress may have wanted claims of that sort to be subject to the control of federal prosecutors rather than private informers. In any event, the First Congress later selected qui tam enforcement for anticorruption provisions of a subsequent bill taxing distilled spirits. See infra note 403 and accompanying text.

393 An Act to Provide More Effectually for the Collection of the Duties Imposed by Law on Goods, Wares and Merchandise Imported into the United States, and on the Tonnage of Ships or Vessels, ch. 35, 1 Stat. 145 (1790).

394 Id. $\S 1$. The statute also authorized new categories of customs officers, allowing construction of up to ten new "cutters" to help enforce the revenue laws, as well as smaller boats, and providing for hiring of officers and sailors. Id. §§ 62-65. 
directed at officers failing to take the oath of office was eliminated, and the two hundred dollar forfeiture was now allocated "to the use of the United States." 395 However, the other qui tam provision directed at customs officers in the original statute was expanded. The qui tam forfeiture of $\$ 100$ was still enforceable against any collector, naval officer, or surveyor who failed to post "a fair table of the rates of fees and duties demandable by law," but now also applied to an officer who failed to "give a receipt for the fees he shall receive, specifying the particulars." 396

Near the end of its term, the First Congress adopted a major new piece of tax legislation, the Distilled Spirits Act, that adjusted rates on imported liquor and imposed new duties on spirits distilled within the United States. ${ }^{397}$ Consistent with Treasury Secretary Hamilton's earlier recommendation, Congress divided the country into statewide revenue districts and created a supervisor of revenue for each district. ${ }^{398}$ The supervisors of revenue were responsible for appointing inspectors to oversee imports of distilled spirits as well as inspecting the products of domestic distilleries. ${ }^{399}$ The Act imposed forfeitures on private persons designed to force importers and domestic distillers to submit to the inspection process, ${ }^{400}$ maintain proper documenta-

$395 I d . \S 5$. Congress may have concluded that sufficient oversight was offered through the provision for certification that the oath had been administered, without the need for additional monitoring by qui tam informers. See supra note 392.

396 An Act to Provide More Effectually for the Collection of the Duties Imposed by Law on Goods, Wares and Merchandise Imported into the United States, and on the Tonnage of Ships or Vessels, ch. 35, 1 Stat. 145, $\$ 55$ (1790). The new provision retained the cause of action for the "party grieved" by an officer charging higher fees than allowed. Id. With respect to the other penalties in the revised statute, the legislation still required that they be "sued for ... in the name of the United States"; such suits could be brought by the collectors of the relevant port, but the law no longer specified that only the collector could prosecute the action. Id. $\S 67$. The provision omitted the earlier statutory exception for "cases of penalty relating to an officer of the customs," see Collection Act, supra note 370, $\S 36$, potentially creating some ambiguity, but section 55 seems relatively clear in allowing suit by an informer against an officer. See An Act to Provide More Effectually for the Collection of the Duties Imposed by Law on Goods, Wares and Merchandise Imported into the United States, and on the Tonnage of Ships or Vessels, ch. 35, 1 Stat. 145, $\$ 55$ (1790).

397 An Act Repealing, After the Last Day of June Next, the Duties Heretofore Laid upon Distilled Spirits Imported from Abroad, and Laying Others in Their Stead; and Also upon Spirits Distilled Within the United States, and for Appropriating the Same, ch. 15, 1 Stat. 199 (1791).

$398 I d . \S 4$.

399 Id. $\$ \S 7,11,18$.

400 Id. $\$ 8$ (forfeiture for importing distilled spirits without reporting for inspection), $\S 9$ (forfeiture for landing distilled spirits without a permit), $\$ 19$ (forfeiture for removing spirits from a domestic distillery before branding by an inspector), $§ 27$ (forfeiture for failing to make due entry of preexisting stock of imported spirits with the officer of inspection), $\S 48$ (forfeiture for obstructing or hindering supervisor of revenue or officer of inspection), $\$ 7$ (forfeiture for painting "office of inspection" on any building other than official inspection house). 
tion, ${ }^{401}$ and pay duties without evasion or corruption. ${ }^{402}$ The statute also included forfeitures for fraud or corruption by a federal revenue officer. ${ }^{403}$ This time, Congress abandoned its earlier reticence about having qui tam informers enforcing federal tax laws. Unless otherwise specified, all penalties and forfeitures in the statute (those against private parties and those against revenue officers) were subject to qui tam enforcement:

$[\mathrm{O}]$ ne half of all penalties and forfeitures incurred by virtue of this act, except as above provided, shall be for the benefit of the person or persons who shall make a seizure, or who shall first discover the matter or thing whereby the same shall have been incurred; and the other half to the use of the United States. And such penalty and forfeiture shall be recoverable with costs of suit, by action of debt, in the name of the person or persons intitled thereto, or by information, in the name of the United States of America. ${ }^{404}$

The Act instructed federal attorneys to bring enforcement actions upon application and contemplated that federal revenue officers would be entitled to benefit from forfeitures under the statute, but nothing in the language limited the enforcement provision to actions initiated by federal officials. ${ }^{405}$

Given that the earlier Collection Acts did not authorize qui tam enforcement against private parties and made only minimal use of qui tam monitor-

$401 I d . \S 10$ (forfeiture for moving distilled spirits from one port to another without a certificate of inspection), $\S 13$ (forfeiture for selling distilled spirits without delivering a certificate of inspection to the purchaser), $\$ 28$ (forfeiture of containers of distilled spirits unmarked and unaccompanied by certificate), $\S 35$ (forfeiture by distiller neglecting to maintain or permit inspection of books).

$402 I d . \$ 20$ (forfeiture for removing spirits from a distillery at night), $\$ 30$ (forfeiture for rubbing out or defacing marks on container of distilled spirits), $\S 31$ (forfeiture for putting new spirits in container marked "Old Stock" or keeping old stock beyond deadline for sale), $\S 32$ (forfeiture of spirits fraudulently concealed to evade duties), $\S 33$ (forfeiture of spirits imported in undersized containers), $\$ 45$ (forfeiture for counterfeiting or forging certificates), $\S 47$ (forfeiture for bribing supervisor of revenue or officer of inspection), $\S 55$ (forfeiture for relanding spirits designated for exportation).

403 The anticorruption provision read:

[I]f any such supervisor or other officer, shall enter into any collusion with any person or persons for violating or evading any of the provisions of this act, or the duties hereby imposed, or shall fraudulently concur in the delivery of any of the said spirits, out of any house, building or place, wherein the same are deposited, without payment or security for the payment of the duties thereupon, or shall falsely or fraudulently mark any cask, case or vessel, contrary to any of the said provisions, or shall embezzle the public money or otherwise be guilty of fraud in his office, such supervisor or other officer shall for every such offence forfeit the sum of one thousand dollars, and upon conviction of any of the said offences, shall forfeit his office, and shall be disqualified for holding any other office under the United States.

Id. $\S 49$; see also id. $\$ 39$ (punishments for oppression or extortion by supervisor or inspector).

404 Id. $\$ 44$.

$405 I d$. There was a forfeiture in the statute that could only be enforced by the supervisor of revenue for the benefit of the United States. Id. $§ 25$ (forfeiture for failing to put up sign or disclose existence of distillery). 
ing for federal officials, why did the First Congress greatly expand qui tam enforcement of the tax laws in the new Distilled Spirits Act? The change in enforcement methods likely responded to Alexander Hamilton's report about the inadequacy of centralized monitoring of a dispersed network of customs officials, combined with a new, more challenging tax collection environment. Under the new legislation, federal tax collection efforts would be more widely distributed throughout the territory of the United States, since duties were no longer concentrated just in ports and coastal areas. Liquor could be distilled anywhere in the country. Moreover, under the new legislation, federal officials would enter into long-term, continuing relationships with domestic distillers regulated by the statute, creating greater opportunities for corruption of federal revenue officers. Consequently, Congress not only adopted Secretary Hamilton's recommendation to appoint regional bureaucrats to monitor federal revenue officers, but also vastly expanded the role of qui tam informers as a supplementary means of monitoring the lawfulness of tax enforcement activities.

\section{Census Officials}

The First Congress adopted legislation to arrange for the initial United States census, which the Constitution required to take place within three years after Congress began meeting. ${ }^{406}$ The census was a matter of substantial political consequence in light of the constitutional directive that "Representatives and direct Taxes shall be apportioned among the several States . . according to their respective Numbers." 407 Many expected the census to significantly alter the allocation of congressional seats established in the initial Constitution, shifting power in the House of Representatives away from southern states and toward eastern states. ${ }^{408}$ As it turned out, the initial census did little to change the regional balance of power. What might be

406 U.S. Const. art. I, § 2. The version of the enumeration bill that first passed the House would have provided for gathering additional information on matters like the occupations of residents, something Madison believed would be useful to legislators and aid the "science of Political Economy." Letter from James Madison to Thomas Jefferson (Feb. 14, 1790), in 18 Documentary History, supra note 365, at 517, 518. He reported to Jefferson that this language "was thrown out by the Senate as a waste of trouble and supplying materials for idle people to make a book." Id.

407 U.S. Const. art. I, § 2. For these purposes, the Constitution notoriously directed that the count should add to "the whole Number of free Persons, including those bound to Service for a Term of Years, and excluding Indians not taxed, three fifths of all other Persons." Id.

408 See Newspaper Correspondence, in 20 Documentary History, supra note 365, at 2063, 2064 (newspaper article expressing view that eastern influence will increase after census). There are indications that some eastern members of Congress wanted the census to take place as quickly as possible and that some southern members sought for more time. See New-York Daily Gazette (Feb. 9, 1790), in 12 Documentary History, supra note 365, at 183 (remarks of Mr. Jackson from Georgia); Letter from Henry Wynkoop to Reading Beatty (Feb. 4, 1790), in 18 Documentary History, supra note 365, at 416 ("[M] uch Conversation was had but nothing done respecting the enumeration[;] the Southern Gentle- 
thought of as eastern states (New York, Connecticut, Rhode Island, Massachusetts, New Hampshire, and Vermont) had a combined representation of 25/69 seats (36.2\%) in the House of Representatives immediately before the 1790 census results were taken into account and a combined representation of 39/105 seats $(37.1 \%)$ after the census results were factored in; likewise, what might be deemed the southern states (Virginia, Kentucky, North Carolina, South Carolina, and Georgia) had a combined representation of 25/69 seats $(36.2 \%)$ before reallocation and 39/105 (37.1\%) afterwards. ${ }^{409}$ Some states did gain or lose ground within each region. In the South, the biggest winner was Virginia, which grew from $10 / 69$ seats $(14.5 \%)$ to $19 / 105$ seats (18.1\%), while the biggest loser was Georgia, which diminished from 3/69 $(4.3 \%)$ to $2 / 105(1.9 \%){ }^{410}$ The biggest winner in the East was Massachusetts, which grew from $8 / 69(11.6 \%)$ to $14 / 105(13.3 \%)$, while the biggest loser was Vermont, which lost ground in terms of percentage of the total legislative body, going from $2 / 69(2.9 \%)$ to $2 / 105(1.9 \%){ }^{411}$

The Enumeration Act made federal marshals responsible for overseeing the census in each judicial district, aided by assistants hired to visit each household and conduct the actual enumeration. ${ }^{412}$ The census was to begin the first Monday in August 1790, and the assistants were required to make their returns to the marshal within nine months. ${ }^{413}$ The marshals had until September 1, 1791, to submit total figures to the President. ${ }^{414}$ Two provisions of the legislation established forfeitures applicable to census officials. Under section 2 of the statute, "every assistant failing to make return, or making a false return of the enumeration to the marshal, within the time by this

men are disposed to cast every Obstacle in its way, while those from the eastward generally are disposed to forward it.").

409 See Representatives Apportioned to Each State (1st to 23rd Census, 1790-2010), Office of the Historian, U.S. House of Representatives, http://foxx.house.gov/ uploadedfiles/state_apportionment.pdf (last visited Nov. 28, 2017). The figure of sixtynine representatives before reapportionment counts the original sixty-five specified in Article I, Section 2 of the Constitution, plus two each for Vermont and Kentucky, which were added to the union and given representation in Congress before the effects of the 1790 census were factored in. See An Act for Apportioning Representatives Among the Several States, According to the First Enumeration, ch. 23, 1 Stat. 253 (1792); An Act Regulating the Number of Representatives to Be Chosen by the States of Kentucky and Vermont, ch. 9, 1 Stat. 191 (1791). For each state, the number of representatives before/after the 1792 reapportionment legislation was: Connecticut, 5/7; Delaware, 1/1; Georgia, 3/2; Kentucky, 2/2; Maryland, 6/8; Massachusetts, 8/14; New Hampshire, 3/4; New Jersey, 4/5; New York, 6/10; Pennsylvania, 8/13; North Carolina, 5/10; Rhode Island, 1/2; South Carolina, 5/6; Vermont, 2/2; and Virginia, 10/19.

410 See supra note 409.

$411 I d$.

412 An Act Providing for the Enumeration of the Inhabitants of the United States, ch. II, § 1, 1 Stat. 101 (1790).

$413 I d$.

414 Id. $\$ 3$. 
act limited, shall forfeit the sum of two hundred dollars." ${ }^{415}$ Section 3 established forfeitures applicable to the marshal:

[E]very marshal failing to file the returns of his assistants, or any of them, with the clerks of their respective district courts, or failing to return the aggregate amount of each description of persons in their respective districts, as the same shall appear from said returns, to the President of the United States, within the time limited by this act, shall, for every such offence, forfeit the sum of eight hundred dollars; all which forfeitures shall be recoverable in the courts of the districts where the offences shall be committed, or in the circuit courts to be held within the same, by action of debt, information or indictment; the one half thereof to the use of the United States, and the other half to the informer; but where the prosecution shall be first instituted on behalf of the United States, the whole shall accrue to their use. ${ }^{416}$

Section 3 clearly provided for qui tam litigation as one enforcement method, alongside enforcement by public officials. While somewhat ambiguous, the language "all which forfeitures" in section 3 likely extends to forfeitures of assistants under section 2 as well as those for marshals, since section 2 did not provide another method of enforcement. Qui tam enforcement against census assistants would make sense because of the decentralized nature of their work, which took them throughout the populated territory of the United States, including areas distant from other federal officials. Centralized monitoring to prevent false returns by the assistants would be nearly impossible. ${ }^{417}$ Qui tam enforcement would significantly increase the chances that a census assistant's misreported numbers would be discovered and prosecuted. In any event, the statute unambiguously provided for qui tam enforcement against federal marshals, a decision explicable by the importance of ensuring as accurate a count as possible.

\section{Treasury Officials}

The Act creating the Department of the Treasury contained multiple forfeitures that were likely subject to qui tam enforcement and, at the very least, established rewards for private citizens providing information to support enforcement actions. The statute authorized appointment of "a Secretary of the Treasury, to be deemed head of the department; a Comptroller,

\section{$415 \quad I d . \S 2$.}

$416 \quad I d . \$ 3$.

417 The nature of the enforcement problem is illustrated by correspondence between James Madison and Edward Carrington, a federal marshal in Virginia. The bill included a provision for census assistants to collect a $\$ 20$ forfeiture from persons who failed to give a true account of those residing in a home. Id. $\S 6$. Carrington worried that under the Judiciary Act, suits to enforce these penalties would have to be filed in federal district courts "to which it will be impossible for the assistants from the distant parts of the Country to resort for such small Sums . . nor indeed will they in cases of false returns be able to establish their Suits without witnesses." Letter from Edward Carrington to James Madison (May 3, 1790), in 19 Documentary History, supra note 365, at 1419. Carrington thought state courts should be given concurrent jurisdiction over these penalties "or none will ever be prosecuted for." Id. 
an Auditor, a Treasurer, a Register, and an Assistant to the Secretary of the Treasury." 418 Section 8 sought to prevent conflicts of interest and abuses of office:

$[\mathrm{N}]$ o person appointed to any office instituted by this act, shall directly or indirectly be concerned or interested in carrying on the business of trade or commerce, or be owner in whole or in part of any sea-vessel, or purchase by himself, or another in trust for him, any public lands or other public property, or be concerned in the purchase or disposal of any public securities of any State, or of the United States, or take or apply to his own use, any emolument or gain for negotiating or transacting any business in the said department, other than what shall be allowed by law. ${ }^{419}$

Violation of these restrictions was deemed a "high misdemeanor" and the officer would "forfeit to the United States the penalty of three thousand dollars, and shall upon conviction be removed from office, and forever thereafter incapable of holding any office under the United States." ${ }^{20}$ The statute provided for an informer to share the money recovered in an enforcement action: "[I]f any other person than a public prosecutor shall give information of any such offence, upon which a prosecution and conviction shall be had, one half the aforesaid penalty of three thousand dollars, when recovered, shall be for the use of the person giving such information." 421 Assuming "give information" here authorized the filing of an action, this provision allowed qui tam enforcement. ${ }^{422}$ The Supreme Court has said that "[s] tatutes providing for a reward to informers which do not specifically either authorize or forbid the informer to institute the action are construed to authorize him to sue." 423 This forfeiture provision did not contain language like the initial Collection Act, passed a little over a month earlier, which specified that penalty actions against private parties were to be brought "by the collector of the district where the same accrued, and not otherwise." 424

Qui tam litigation was clearly authorized in later legislation establishing the First Bank of the United States. ${ }^{425}$ Section 8 of the statute created a treble-value qui tam forfeiture against individuals involved in prohibited commercial transactions by the bank, "one half thereof to the use of the informer, and the other half thereof to the use of the United States, to be

\footnotetext{
418 An Act to Establish the Treasury Department, ch. 12, § 1, 1 Stat. 65 (1789).

419 Id. $\$ 8$.

$420 I d$.

421 Id.

422 An "information" was one of the legal mechanisms traditionally available to qui tam informers. See supra notes 117-19 and accompanying text.

423 United States ex rel. Marcus v. Hess, 317 U.S. 537, 541 n.4 (1943). The Vermont Agency Court described this discussion from Marcus as "dictum." See Vt. Agency of Nat. Res. v. United States ex rel. Stevens, 529 U.S. 765, 777 n.7 (2000).

424 Collection Act, supra note $370, \S 36$.

425 See An Act to Incorporate the Subscribers to the Bank of the United States, ch. 10, 1 Stat. 191 (1791).
} 
recovered with costs of suit." 426 Section 9 enforced a ban on lending or advancing more than $\$ 100,000$ to the United States government (or more than $\$ 50,000$ to a state or foreign government) without previous authorization by a law of the United States. ${ }^{427}$ The forfeiture for violating this rule was allocated as follows:

$[\mathrm{A}] 11$ and every person and persons, by and with whose order, agreement, consent, approbation, or connivance, such unlawful advance or loan shall have been made, upon conviction thereof, shall forfeit and pay, for every such offence, treble the value or amount of the sum or sums which shall have been so unlawfully advanced or lent; one fifth thereof to the use of the informer, and the residue thereof to the use of the United States. ${ }^{428}$

Treasury officials would presumably be among the individuals most likely to violate the restriction on agreeing to a prohibited loan or advance to the United States government.

In the case of revenue officers and census workers, qui tam enforcement made sense as a means of monitoring decentralized government conduct. Activities subject to qui tam regulation would take place wherever liquor was distilled or wherever residents of the United States lived. That rationale for qui tam monitoring seems less relevant for officers of the Treasury Department stationed in the nation's capital. A stronger reason for employing qui tam enforcement in this context would be to preserve congressional control of the public fisc and thereby foster public confidence in the lawful conduct of the nation's financial affairs.

\section{Postal Workers}

Before ratification of the Constitution, the Articles of Confederation conferred on Congress the power of "establishing and regulating post-offices from one state to another, throughout all the united states, and exacting such postage on the papers passing thro' the same as may be requisite to defray the expences of the said office." 429 When the new Constitution came into effect, the Post Office was operating under an ordinance enacted by the Confederation Congress in October 1782.430 The ordinance imposed a variety of restrictions on postal workers, including prohibitions on opening, embezzling, or destroying the mail, and required an oath that each employee would abide by the legislation. ${ }^{431}$ These obligations were enforced through forfeitures recoverable by government officials in state courts. A Postmaster General who violated his oath could forfeit $\$ 1000$ for the benefit of the Post

\footnotetext{
$426 \quad I d . \S 8$.

427 Id. $\$ 9$.

$428 I d$.

429 Articles of Confederation of 1781, art. IX, para. 4.

430 An Ordinance for Regulating the Post Office of the United States of America (1782), in Journals of the Continental Congress, at 670.

$431 I d$. at 671 (requiring postal employees to take oath to "well and faithfully do, execute, perform and fulfil every duty required of me, and abstain from every act and thing forbidden" by the legislation).
} 
Office in an action pursued by the Treasurer of the United States. ${ }^{432}$ A postmaster, post-rider, or other Post Office employee who violated his oath could forfeit $\$ 300$ in a state court lawsuit pursued by the Postmaster General. ${ }^{433}$ The Postmaster General and his deputies could also pursue penalties against private parties who carried mail for hire in competition with the federal postal service. ${ }^{434}$

The First Congress provided for appointment of a Postmaster General and for temporary operation of the Post Office under the rules adopted by the Confederation Congress. ${ }^{435}$ The new Congress began work on more permanent Post Office legislation, but did not complete the task before it rose for biennial elections. ${ }^{436}$ During the course of legislative deliberations in the First Congress, President Washington's new Postmaster General recommended " $[\mathrm{a}]$ more accurate description of offences and frauds that may be committed by any person employed" in the department, accompanied by "such penalties as will be most likely to deter from and prevent the actual commission of them." 437 The previous Postmaster General commented on draft legislation that would have continued reliance on centralized supervision and litigation, suggesting that "[c] onsidering the Distance of some of the Offices, \& other Circumstances," the Postmaster General should be allowed at least six months to commence suits against subordinates. ${ }^{438}$

New Hampshire postmaster Jeremiah Libbey, in a letter to Senator John Langdon, commented on a proposal to give the Postmaster General one month after the end of a quarter to bring suit against a postmaster failing to account for monetary receipts:

Suppose ... that a Post Master at Portsmouth [New Hampshire], or Savannah in Georgia-on the first day of [January] (the day the Quarter expires,) should be sick, or some accident happen to him or family that he could not possibly send on his Account \& the money, at the time; on the first day of February, the Post Master General is to commence an Action against him, shall I ask where is the Action to be commenced? where the General Office is kept, 700 or 1000 miles from the place where the Post Master lives? or is it to be commenc'd where the Man lives? If so the Post Master General must give Orders for the Action perhaps, before it can be known whether the Accounts \& moneys were not sent on, [though] not arrived at the General Office . . . . ${ }^{439}$

$432 I d$. at $671-72$.

$433 I d$. at 672.

434 See id. at $672-74$

435 An Act for the Temporary Establishment of the Post-Office, ch. 16, 1 Stat. 70 (1789).

436 See An Act to Continue in Force for a Limited Time, An Act Intituled "An Act for the Temporary Establishment of the Post-Office," ch. 23, 1 Stat. 218 (1791).

437 Report of the Postmaster General (Jan. 22, 1790), in 6 Documentary History, supra note 365 , at $1657,1661-62$.

438 Ebenezer Hazard's Remarks (June 24, 1790), in 6 Documentary History, supra note 365 , at 1704,1706 .

439 Letter from Jeremiah Libbey to John Langdon (June 30, 1790), in 19 Documentary History, supra note 365, at 1973, 1973 (second alteration in original). 
While Libbey was concerned about an unreasonably short statute of limitations, his comments illuminate the difficulty of centralized supervision of subordinates stationed hundreds of miles from the seat of government. The Postmaster General might plausibly monitor financial accounting by postmasters who sent relevant documents to the central office. It would be much more difficult for the Postmaster General to adequately enforce nationwide regulations concerning carriage of mail and charges for services.

Perhaps for such reasons, when the Second Congress enacted legislation to put the Post Office on a more permanent footing, it decided to shift to a system of qui tam enforcement. ${ }^{440}$ The statute provided that "all pecuniary penalties and forfeitures, incurred under this act, shall be, one half for the use of the person or persons informing and prosecuting for the same, the other half to the use of the United States." 441 The statute contained a number of regulations of private conduct enforceable through qui tam litigation, including forfeitures for obstructing or delaying the mail ${ }^{442}$ for a ferry operator negligently delaying or refusing to transport mail, ${ }^{443}$ for injuring Post Office revenue by operating a competing mail service, ${ }^{444}$ and for counterfeiting someone's handwriting to avoid paying postage. ${ }^{445}$ More significantly for our purposes, the Act also included several qui tam forfeitures applicable to postal service employees, including penalties for demanding or accepting a higher postage rate than provided by law or an additional gratuity or reward; ${ }^{446}$ failing to account for "bye or way-letters" picked up along the route; ${ }^{447}$ opening, delaying, secreting, embezzling, destroying, or deserting the mail, or otherwise carrying mail contrary to the Act; ${ }^{448}$ and delaying or embezzling newspapers sent through the mail. ${ }^{449}$

\section{Federal Indian Agents}

In addition to qui tam regulation of postal employees, the Second Congress enacted qui tam legislation to monitor federal employees managing trade with Native American tribes. The statute prohibited trade with the tribes except pursuant to a federal license. ${ }^{450}$ Obtaining a license required the applicant to post a bond that would be forfeited if the person did not

440 See An Act to Establish the Post-Office and Post Roads Within the United States, ch. 7, 1 Stat. 232 (1792).

$\begin{array}{ll}441 & \text { Id. } \$ 25 . \\ 442 & \text { Id. } \$ 5 . \\ 443 & \text { Id. } \\ 444 & \text { Id. } \$ 14 . \\ 445 & \text { Id. } \$ 20 . \\ 446 & \text { Id. } \$ 11 . \\ 447 & \text { Id. } \$ 15 . \\ 448 & \text { Id. } \S 16 . \\ 449 & \text { Id. } \$ 22 .\end{array}$

450 An Act to Regulate Trade and Intercourse with the Indian Tribes, ch. 19, § 1, 1 Stat. 329 (1793). 
comply with trade regulations adopted by the President. ${ }^{451}$ A person found in Indian territory without a license and with merchandise typically sold to Native Americans would forfeit the merchandise and pay a fine. ${ }^{452}$ A larger forfeiture applied to someone who attempted to settle in Indian territory, ${ }^{453}$ or purported to purchase land from Native Americans. ${ }^{454}$ A person who bought horses in Indian territory without a license was also liable to a forfeiture. ${ }^{455}$

One forfeiture under the statute applied to federal officials with licensing authority. Under the statute, no agent, superintendent, or other person authorized to grant a license for trade or for purchase of horses could "have any interest or concern in any trade with the Indians, or in the purchase or sale of any horses, to or from any Indian." 456 An officer violating the restriction could forfeit $\$ 1000$ and face a possible term of imprisonment. ${ }^{457}$ The statute authorized qui tam enforcement, providing that "all fines and forfeitures" under the Act would be split "one half to the use of the informant, and the other half, to the use of the United States, except where the prosecution shall be first instituted on behalf of the United States, in which case, the whole shall be to their use." 458

\section{Constitutional Implications of Qui Tam Regulation of GOVERNMENT OfFicials}

When Morrison considered the constitutionality of "independent" prosecutions of executive branch officers and when Lujan addressed civil litigation against federal officials, the Supreme Court paid minimal attention to mechanisms used to regulate government officials when the Constitution was ratified in 1789. This Article has highlighted the common eighteenth-century practice of policing government conduct through qui tam legislation, a practice followed in numerous statutes enacted by our earliest Congresses. This Part will consider what the history of qui tam regulation of government officials might tell us about the constitutional issues raised in Lujan and Morrison, beginning with the Article III standing question and then moving on to issues arising under Article II.

\section{A. Qui Tam Litigation and Article III Standing}

Nearly fifty years ago, Raoul Berger authored a Yale Law Journal article challenging the Supreme Court's developing standing jurisprudence on his-

$\begin{array}{ll}451 & I d . \\ 452 & I d . \S 3 . \\ 453 & I d . \S 5 . \\ 454 & I d . \S 8 . \\ 455 & I d . \S 6 . \\ 456 & I d . \S 7 . \\ 457 & I d . \\ 458 & I d . \S 12 .\end{array}$


torical grounds. ${ }^{459}$ Professor Berger drew on Louis Jaffe's earlier work concerning the ability of "strangers" to seek prerogative writs in English courts challenging actions taken without jurisdiction. ${ }^{460}$ In addition, Berger noted the long tradition of "informer" or qui tam statutes: "The early English practice in prohibition, certiorari, and quo warranto is not the sole indication of easy access to 'public actions'; there were in addition the centuries-old 'informers' actions" pursued under statutes that "offered financial inducements to strangers to prosecute such actions." 461 Steven Winter expanded on the evidence offered by earlier scholars, providing additional detail on the use of qui tam legislation in early state and federal law and noting the existence of qui tam statutes directed at public officials. ${ }^{462}$ After the Supreme Court's decision in Lujan, Cass Sunstein wrote an ambitious and influential article that drew on the earlier historical research to criticize the Court's standing jurisprudence. ${ }^{463}$ Sunstein argued that the law of standing was a twentieth-century invention and that the only relevant question for determining the presence of an Article III case or controversy is whether the law affords the plaintiff a cause of action, something Congress had done in Lujan through the citizen suit provision of the ESA. ${ }^{464}$

Evidence concerning American reception of the English prerogative writs lies outside the scope of this Article. ${ }^{465}$ Our review of the long tradition

459 See Raoul Berger, Standing to Sue in Public Actions: Is It a Constitutional Requirement?, 78 YALE L.J. 816 (1969).

$460 I d$. at 819 ("When we turn to pre-Constitution English law for light on the meaning of 'case or controversy,' we find that attacks by strangers on action in excess of jurisdiction were a traditional concern of the courts in Westminster. The writ of prohibition supplies perhaps the clearest example.").

461 Id. at 825-26.

462 See Steven L. Winter, The Metaphor of Standing and the Problem of Self-Governance, 40 Stan. L. Rev. 1371, 1406-09 (1988).

463 See Sunstein, supra note 33, at 170-79.

464 See id. at 222-23; see also Caminker, supra note 137, at 381 ("Article III standing requirements ought to be considered satisfied whenever the plaintiff seeking to invoke the Federal judicial power asserts a cause of action pursuant to a congressional statute.").

465 Ann Woolhandler and Caleb Nelson have responded to standing skeptics, seeking to demonstrate a long tradition in various areas of law of limiting the extent to which private parties may litigate interests of the public. See Ann Woolhandler \& Caleb Nelson, Does History Defeat Standing Doctrine?, 102 Мich. L. Rev. 689, 691 (2004) (“[E]ighteenthand nineteenth-century courts were well aware of the need for proper parties, and they linked that issue to the distinction between public and private rights. Courts regularly designated some areas of litigation as being under public control and others as being under private control. Within the area of private control, moreover, courts paid close attention to whether the correct private parties were before them."). In considering historical evidence concerning English prerogative writs, it might be significant that many of the cases relied on by standing skeptics involved challenges to actions taken without jurisdiction. See Berger, supra note 459, at 819-24. It is not clear that principles concerning who may challenge an act taken without jurisdiction should necessarily carry over to other sorts of legal claims. For instance, since federal courts must notice defects in jurisdiction sua sponte, they could not rely on standing principles to ignore a suggestion of lack of jurisdiction filed by a stranger to the litigation. See Bender v. Williamsport Area Sch. Dist., 475 
of qui tam regulation of public officials, on the other hand, puts us in a good position to consider the relevance of qui tam legislation to the debate over Article III standing doctrine. ${ }^{466}$ To the extent the Supreme Court grounds its standing doctrine on historical practice when the Constitution was adopted, ${ }^{467}$ it seems fair to conclude that Lujan made two related mistakes in its explication of standing doctrine. The Court erred when it identified "particularized" injury as part of the "irreducible constitutional minimum" of standing. ${ }^{468}$ It compounded the error when it concluded that Article III bars Congress from authorizing private litigation of generalized grievances about unlawful executive branch activity. ${ }^{469}$ In the five centuries leading up to the framing of our Constitution, it was routine for Anglo-American legislatures to authorize litigation of generalized grievances by uninjured informers, including generalized grievances about unlawful government conduct. ${ }^{470}$ A qui tam informer did not need to allege individual injury "because every Offence, for which such Action is brought, is supposed to be a general Grievance to every Body." 471 There was no expectation in a popular action of "Damage . . . to the Demandant in particular." 472

If the Lujan Court erred in its articulation of standing doctrine, does that mean the Court reached the wrong outcome in light of the citizen suit provision of the ESA? If Professor Sunstein is correct that Congress may create universal standing by simply affording a cause of action to anyone who will sue, the ESA citizen suit provision could arguably be understood to include such a grant. One still might doubt whether Congress intended the ESA's citizen suit provision to confer standing on uninjured plaintiffs. The provision authorized "any person" to file a civil action for injunctive relief "on his own behalf," 473 a formulation that might imply a statutory requirement to show some individual interest in the relief sought. But, for the purpose of exploring Article III issues in light of the history of qui tam litigation, we will assume that Congress indeed intended to authorize suit by "any person"-whether or not injured in some individual way-to seek injunctive relief based on a federal agency's misapplication of the ESA.

While Professor Sunstein may be correct about congressional power and the proper outcome in Lujan, I am not convinced that the history of qui tam legislation necessarily drives us to the conclusions he reached. One can dis-

U.S. 534, 541 (1986) (discussing how every federal appellate court must satisfy itself of its own jurisdiction and that of the lower courts, even if parties are prepared to concede jurisdiction).

466 Woolhandler and Nelson acknowledge that standing skeptics "properly emphasize [qui tam] statutes as telling evidence for their position." Woolhandler \& Nelson, supra note 465 , at 726 .

467 See supra notes 99-103 and accompanying text.

468 Lujan v. Defs. of Wildlife, 504 U.S. 555, 560 (1992).

469 Id. at 573-76.

470 See supra Part II.

4712 Hawkins, supra note 13, at 267.

$472 I d$. at 273-74.

473 See 16 U.S.C. \$1540(g) (2012). 
tinguish qui tam statutes from the ESA citizen suit provision on grounds that might justify differential treatment for purposes of Article III standing. Lujan's reading of Article III was guided by the Court's understanding that the case-or-controversy limitation was designed to confine the courts to a historically judicial role, so that federal judges would not be drawn into tasks more applicable to the political branches. Our review of qui tam history allows us a clearer picture of the role judges actually played in the centuries leading up to the adoption of the Constitution, but that role still might be distinguishable from the one Professor Sunstein envisions judges playing under the ESA.

The typical qui tam statute did not authorize pure private representation of the public. Instead, the bounty provision of a qui tam statute was understood to create a private financial interest that the informer pursued alongside the public interest in enforcing the law. ${ }^{474}$ The Latin phrase giving rise to the qui tam label—rendered by Blackstone as "qui tam pro "domino rege, $\mathcal{E} \sigma$, quam pro seipso in hac parte sequitur" 475 _ speaks of a litigant who sues "for himself" as well as suing "for the king." 476 The informer's bounty, like the injury suffered by an aggrieved party, gives the qui tam informer a personal and private interest in the litigation that motivates and justifies the individual's invocation of judicial aid. The individual right conveyed by the informer's bounty explains a letter from attorney Richard Harison to Treasury Secretary Alexander Hamilton, opining that a presidential pardon "cannot extend to affect the rights of Individuals" and therefore could not remit the portion of a statutory fine or penalty "expressly given to any Individual" unless the informer consented or the statute qualified the individual's right to payment. ${ }^{477}$

Professor Sunstein suggests that no Article III value would be served by recognizing standing when Congress offers a pecuniary inducement to sue but denying congressional power to grant universal standing in the absence of a bounty provision. ${ }^{478}$ Justice Holmes offered a possible response when he commented that " $[\mathrm{u}]$ pon this point a page of history is worth a volume of logic." ${ }^{479}$ Holmes was justifying resort to the "traditional use" of the constitutional term "direct tax" where a litigant sought to attach the label to a sort of estate tax that "always has been regarded as the antithesis of a direct tax." 480 Similarly, where we seek to determine how the Framers understood the terms

474 Sunstein, supra note 33 , at 176 .

4753 Blackstone, supra note 36 , at $* 160$.

476 Qui Tam Action, Black's Law Dictionary (10th ed. 2014) ("who as well for the king as for himself sues in this matter").

477 See Letter from Richard Harison to Alexander Hamilton (May 24, 1791), in ThE Papers of Alexander Hamilton Digital Edition (Harold C. Syrett ed., 2011), http:// rotunda.upress.virginia.edu/founders/ARHN-01-08-02-0326; see also Beth A. Colgan, Reviving the Excessive Fines Clause, 102 Calif. L. Rev. 277, 335 n.292 (2014).

478 Sunstein, supra note 33, at 176-77.

479 N.Y. Tr. Co. v. Eisner, 256 U.S. 345, 349 (1921).

$480 I d$. 
"case" and "controversy" in Article III, perhaps historical usage should count more than policy coherence.

In any event, apart from the informer's bounty, the citizen suit provision at issue in Lujan differs from the qui tam statutes reviewed in Part II in other important respects that may implicate Article III concerns. The qui tam statutes we examined imposed a financial penalty on an individual government official for a particular unlawful act identified with some precision in the legislation. In defending the Article III standing of qui tam litigants, Evan Caminker noted that "qui tam statutes impose penalties for specific misconduct" and therefore present legal issues in a "concrete factual setting." 481 The ESA's citizen suit provision, on the other hand, was not limited to specific misconduct committed by particular officials. It allowed "any person" to sue for an injunction against any person or federal agency "alleged to be in violation of any provision of this chapter." 482 Congress took a complex regulatory regime imposing numerous duties, some relatively indeterminate, and authorized wholesale private enforcement.

The broad sweep of the ESA citizen suit provision arguably created a risk that courts would be drawn into a policy-making role that extended beyond eighteenth-century forms of judicial conduct. We seek to guard against judicial policymaking today through principles of statutory interpretation embodied in the Chevron doctrine, but similar concerns could be thought to underlie Article III's case or controversy limitation. ${ }^{483}$ Universal standing to litigate any statutory interpretation issue under the ESA-as opposed to enforcing specific duties of particular government officials or specific rights of particular plaintiffs-might serve as an invitation to judicial policymaking. Of course, judicial policymaking could also occur under a citizen suit provision applied per Lujan. However, one might reasonably believe that the judicial temptation to embrace a free-wheeling policy role will be heightened in cases where the only interests in view are those of the public at large. Limiting citizen suits to plaintiffs with particularized interests at stake arguably tends to point judges in the direction of protecting private rights, a common form of eighteenth-century adjudication.

To put it another way, if understood as a grant of universal standing, the ESA citizen suit provision sought to make courts perpetual monitors of executive branch enforcement of a wide-ranging regulatory regime without being

481 See Caminker, supra note 137, at 381 (internal quotation marks omitted).

482 Lujan v. Defs. of Wildlife, 504 U.S. 555, 572 (1992) (quoting 16 U.S.C. $§ 1540(\mathrm{~g})$ (1982)).

483 See Chevron U.S.A. Inc. v. Nat. Res. Def. Council, Inc., 467 U.S. 837 (1984); Thomas J. Miles \& Cass R. Sunstein, Do Judges Make Regulatory Policy? An Empirical Investigation of Chevron, 73 U. CHI. L. Rev. 823, 824 (2006) ("For its defenders, Chevron signaled a healthy awareness that the resolution of ambiguities calls for judgments of policy-and an accompanying belief that such judgments should be made by political actors, not by the federal judiciary."). Imagine a hypothetical statute, for instance, in which Congress purported to empower federal courts to adopt regulations implementing the ESA in the course of "litigation" pursued by private litigants. A court might well find such a delegation of regulatory authority a violation of the Article III case or controversy limitation. 
entirely clear what Congress expected the Executive to do in implementing the statute. A citizen suit provision applied indiscriminately at least arguably assigns the courts a role distinguishable from the role courts historically performed in enforcing qui tam statutes that imposed specific legal duties on individual public officials. A much-discussed passage from Justice Kennedy's concurring opinion in Lujan may help illuminate the point:

In my view, Congress has the power to define injuries and articulate chains of causation that will give rise to a case or controversy where none existed before, and I do not read the Court's opinion to suggest a contrary view. In exercising this power, however, Congress must at the very least identify the injury it seeks to vindicate and relate the injury to the class of persons entitled to bring suit. The citizen-suit provision of the Endangered Species Act does not meet these minimal requirements, because while the statute purports to confer a right on "any person ... to enjoin ... the United States and any other governmental instrumentality or agency ... who is alleged to be in violation of any provision of this chapter," it does not of its own force establish that there is an injury in "any person" by virtue of any "violation." 484

In speaking of Congress's failure to identify an "injury" suffered by authorized litigants, Justice Kennedy appears to be concerned about the lack of legislative specificity in identifying statutory duties subject to private enforcement and the interests that would justify allowing private litigants to enforce those duties. 485 The history reviewed in Part II shows that particularized "injury" was not historically required for judicial resolution of a qui tam action, but perhaps Article III could still be understood to require that private plaintiffs show a particularized "interest" (either a legal injury or a financial interest arising from a bounty provision) or that litigation against public officials seeks enforcement of particularized "duties" imposed by statute. None of this establishes that Professor Sunstein was wrong in his view of congressional power, but only that his position is not compelled by the history of qui tam legislation. Someone who recognizes the inconsistency of Lujan's articulation of standing doctrine with qui tam history could nevertheless conclude that Lujan reached the right result in the case before the Court.

\section{B. Qui Tam Litigation and the Take Care Clause}

Lujan's second ground for rejecting suits by uninjured citizens against executive branch officials rested on the President's responsibilities under Article II of the Constitution. According to the Lujan Court:

To permit Congress to convert the undifferentiated public interest in executive officers' compliance with the law into an "individual right" vindicable in the courts is to permit Congress to transfer from the President to the courts the Chief Executive's most important constitutional duty, to "take Care that the Laws be faithfully executed." It would enable the courts, with the per-

484 Lujan, 504 U.S. at 580 (Kennedy, J., concurring in part and concurring in the judgment) (quoting 16 U.S.C. $\$ 1540$ (g) (1) (A) (1982)) (citing Warth v. Seldin, 422 U.S. 490, $500(1975))$.

485 Id. at $580-81$. 
mission of Congress, "to assume a position of authority over the governmental acts of another and co-equal department," and to become "virtually continuing monitors of the wisdom and soundness of Executive action." 486

Professor Sunstein sees the Lujan opinion as "motivated by many of the concerns expressed in Justice Scalia's dissenting opinion in Morrison v. Olson." 487 Justice Scalia argued unsuccessfully in Morrison that the independent counsel statute usurped a portion of the executive power allocated to the President. ${ }^{488}$ However, Lujan reads the Take Care Clause as embodying a version of the unitary executive principle that excludes certain forms of private litigation against executive officials.

Lujan understands the Take Care Clause to grant the President a semiexclusive constitutional authority to monitor and ensure legal compliance by the President's executive branch subordinates. I use the term "semi-exclusive" because the Lujan Court would allow persons or institutions other than the President to address executive lawlessness in some situations. The Court had no problem with judicial monitoring of the legality of executive conduct as a step toward offering redress to an aggrieved private plaintiff. ${ }^{489}$ The Court would presumably also allow judicial correction of unlawful executive conduct if the litigation was initiated by the President's subordinates, as in a criminal prosecution of an executive official. ${ }^{490}$ Article II gives Congress express power to impeach and remove civil officers for "Treason, Bribery, or other high Crimes and Misdemeanors," ${ }^{91}$ and nothing in Lujan calls into question the congressional power to conduct oversight hearings concerning the legality of executive branch activities. But for the broad range of executive branch conduct that occurs below the congressional radar and that does not injure any particular party with a motive to sue, Lujan leaves the task of ensuring legal compliance exclusively in the hands of the President.

Jack Goldsmith and John Manning note that the Supreme Court invokes the Take Care Clause in a variety of contexts, but "the Court almost never construes the clause, at least not in any conventional way." 492 In other words, the Court "does not look at any of the evidence one would expect an interpreter to consider in determining the clause's relevance to the many uses to which the Court has put it." 493 Their observation applies with particular force to the Court's reading of the Take Care Clause in Lujan. Certainly the

$486 I d$. at 577 (majority opinion) (citations omitted) (first quoting U.S. Const. art. II, $\S 3$; then quoting Massachusetts v. Mellon, 262 U.S. 447, 489 (1923); and then quoting Allen v. Wright, 468 U.S. 737, 760 (1984)).

487 Sunstein, supra note 33, at 193.

488 Morrison v. Olson, 487 U.S. 654, 708 (1988) (Scalia, J., dissenting).

489 See Lujan, 504 U.S. at 575 (person with direct injury has standing to seek review of executive action).

490 See Morrison, 487 U.S. at 695-96 (discussing President's control over prosecution of criminal activity).

491 U.S. Const. art. II, $§ 4$.

492 Jack Goldsmith \& John F. Manning, The Protean Take Care Clause, 164 U. PA. L. REv. 1835, 1853 (2016).

$493 I d$. 
text of Article II does not compel the Court's view of the clause as a semiexclusive grant of power to the President. A provision that instructs the President to make sure something happens does not negate the possibility of a redundant responsibility in other actors. If a state law instructed parents to "take care" that their children are clothed and fed, it would not disable school officials from acting when parental responsibilities have been neglected. ${ }^{494}$ The more natural understanding of the Take Care Clause is that the President's responsibility to ensure faithful execution of the laws exists alongside any oversight provided by Congress or the courts in the exercise of their constitutional functions. ${ }^{495}$

The bigger problem with the Lujan Court's reading of the Take Care Clause, however, is historical rather than textual. As demonstrated in Part II, Article II of the Constitution was drafted against the background of nearly half a millennium of Anglo-American legislation authorizing uninjured common informers to initiate litigation to enforce legal duties of government officials, including officials wielding executive power. From the early fourteenth century to the late eighteenth century, legislatures had routinely enacted qui tam statutes that "convert[ed] the undifferentiated public interest in executive officers' compliance with the law into an 'individual right' vindicable in the courts" and made the courts "virtually continuing monitors" of the legality of executive action. ${ }^{496}$ In this historical context, the earliest Congresses believed the Constitution allowed use of these long-recognized legislative tools to monitor and ensure executive branch compliance with the laws. Congress provided for qui tam enforcement of numerous legal duties of executive revenue officers, census workers, treasury officials, postal workers, and officials regulating trade with Native American tribes. ${ }^{497}$ President Washington did not raise any concern that the litigation authorized might somehow intrude on his Article II authority.

The Take Care Clause was modeled on the New York Constitution of 1777, which instructed the governor to "take care that the laws are faithfully executed to the best of his ability." 498 This constitutional duty coexisted with the state's tradition of qui tam legislation, including legislation directed at

494 Moreover, if a suit against an executive branch official by an uninjured litigant undermines the President's constitutional role under the Take Care Clause, why wouldn't a lawsuit by an injured litigant equally intrude on the President's authority, especially given Lujan's minimalist understanding of what counts as a particularized injury? Both types of litigation have the same consequence of placing the task of responding to allegedly illegal executive branch conduct in judicial hands.

495 Goldsmith \& Manning, supra note 492, at 1860 ("The drafters [of the Take Care Clause] may have insisted that the President ensure the legality or good faith of executive officers while not precluding Congress from specifying other means of policing executive legality.”).

496 Lujan v. Defs. of Wildlife, 504 U.S. 555, 577 (1992) (quoting Allen v. Wright, 468 U.S. 737, 760 (1984)) (some internal quotation marks omitted).

497 See supra notes 366-458 and accompanying text.

498 N.Y. Const. of 1777, art. XIX; see Goldsmith \& Manning, supra note 492, at 1861 \& n.169. 
public officials. ${ }^{499}$ The principal duty of the English King, reflected in his coronation oaths, was "to govern his people according to law." ${ }^{00}$ For centuries preceding our Declaration of Independence and the ratification of our Constitution, the King's duty to enforce the laws was deemed compatible with the tradition of qui tam legislation. ${ }^{501}$ A common informer sued on behalf of the King as well as for himself, suggesting that qui tam litigation was seen as supporting the King's law enforcement mission. ${ }^{502}$ Courts that tried qui tam actions in England and the early American states were not viewed as competitors of the Executive, usurping powers of the King or governor, but were engaged in a common mission of making sure that subordinate officials stayed within legal constraints on their conduct.

Qui tam legislation does tend to undermine the ability of the executive branch to pursue optimal enforcement of a statute through establishment of enforcement priorities and exercise of prosecutorial discretion. ${ }^{503}$ Professor Caminker argues persuasively, however, that executive judgments about whether statutory claims should be pursued "are not constitutionally protected by Article II against congressional override." ${ }^{504}$ Congress, for instance, can dilute executive discretion through civil suit provisions, which have consequences comparable to those of qui tam statutes. ${ }^{505}$ Zachary Price surveys authority suggesting a broad congressional power to regulate the exercise of prosecutorial discretion. ${ }^{506}$ He notes that the Take Care Clause was drafted against the background of the English Bill of Rights, which denied the King authority to suspend or dispense with execution of parliamentary enactments. ${ }^{507}$ While the effect of qui tam legislation on the enforcement discretion of the executive branch should no doubt be taken into account as a policy matter, it does not support the Lujan Court's reading of the Take Care Clause.

Lujan's understanding of the Take Care Clause also seems anachronistic. It is unlikely that late eighteenth-century Americans would have understood the provision to afford the President a semi-exclusive authority to monitor executive branch officials, since any presidential monitoring of a far-

\footnotetext{
499 See supra Section II.B.

5001 William Blackstone, Commentaries $* 226$.

501 See supra Section II.A.

502 Qui Tam Action, Black's Law Dictionary (10th ed. 2014) ("who as well for the king as for himself sues in this matter").

503 Beck, supra note 108, at 583 ("The common informer has little reason to consider broader issues of public policy raised by a particular prosecution, and in fact has a strong financial incentive not to take such considerations into account. The result is that informers pursue litigation that disinterested prosecutors would consider contrary to the public good."); $i d$. at 584-85 (examples of English informers pursuing inappropriate defendants); $i d$. at 620-33 (examples under the Federal False Claims Act).

504 Caminker, supra note 137, at 359-60.

505 Id. at 360 .

506 See Zachary S. Price, Enforcement Discretion and Executive Duty, 67 Vand. L. Rev. 671, 711-16 (2014).

507 See id. at 689-96.
} 
flung federal workforce would necessarily be superficial. When the Constitution was ratified, the United States covered hundreds of thousands of square miles, stretching from Maine (then part of Massachusetts) to Georgia and from the Atlantic to the Northwest Territory (including present day Illinois and Wisconsin). ${ }^{508}$ Those who created the Constitution anticipated that federal officials would engage in activities taking them throughout this vast territory, counting inhabitants, collecting taxes, regulating commerce among states and with Indian tribes, carrying mail, and conducting military operations. ${ }^{509}$ The ultimate size of the federal workforce was uncertain, but it was clear that the country, still burdened by Revolutionary War debts, could not afford a large bureaucracy. ${ }^{510}$ Travel and communication were slow and cumbersome. ${ }^{511}$ Exclusive reliance on centralized presidential monitoring of federal agents would mean little or no monitoring at all for some very significant government functions. This explains why Congress turned to qui tam legislation in several instances where the decentralized nature of federal activity would make presidential supervision difficult. ${ }^{512}$ In sum, the history recounted in Part II and the circumstances prevailing in the eighteenth-century United States make Lujan's reading of the Take Care Clause implausible as a matter of original understanding.

\section{Qui Tam Litigation and the Unitary "Executive Power"}

Apart from the Take Care Clause, we should also consider the implications of qui tam history for the more general Article II executive power questions raised by cases like Morrison. The Morrison Court upheld the independent counsel statute, rejecting the argument that the legislation diverted executive power constitutionally vested in the President. The Court agreed that the independent counsel's investigation and prosecution of federal crimes constituted an exercise of "executive power," but concluded that the President maintained "sufficient control" by virtue of various provisions of the statute, including the power to remove the independent counsel for good cause. ${ }^{513}$ Does the history of qui tam regulation of executive officials support the Court's result in Morrison? Does that history call into question the unitary executive theory, either in the form embodied in the majority opinion or the stronger version advocated in Justice Scalia's dissent?

The best answer to these questions, in my view, derives from Blackstone's comment placing qui tam suits in the category of "popular actions, because

508 See United States, 1789, MAPS ETC, http://etc.usf.edu/maps/pages/700/795/ 795.htm (last visited Nov. 27, 2017).

509 See U.S. Const. art. I, §§ 2, 8; see also McCulloch v. Maryland, 17 U.S. (4 Wheat.) 316, 408 (1819) ("Throughout this vast republic . . revenue is to be collected and expended, armies are to be marched and supported.").

510 See supra notes 367-70 and accompanying text.

511 See supra notes 388-90, 439 and accompanying text.

512 See supra subsections II.C.2 and II.C.4.

513 See supra notes 70-74 and accompanying text. 
they are given to the people in general." 514 The power to bring a qui tam action was not a governmental power, but rather a power exercised by the public with legislative authorization. Under Anglo-American legal tradition, legislatures could place the power to seek forfeitures from public officials for unlawful acts in the hands of other government officers, aggrieved parties, or members of the general public. Since the power to initiate a qui tam action was "given to the people," it was not a governmental power subject to the Constitution's tripartite division among legislative, executive, and judicial powers. ${ }^{515}$ The tradition of qui tam legislation can coexist comfortably with Article II's allocation of all "executive power" to the President because "executive power" is a subcategory of governmental power.

Qui tam legislation developed during centuries in which English and American governments wielded considerably less power than they do today. As a consequence, citizens were often called upon to participate in law enforcement activities or to help extend the government's coercive reach. A sheriff could call on a "posse comitatus" of armed citizens to assist in pursuing a criminal or keeping the peace. ${ }^{516}$ The Judiciary Act of 1789 conferred a version of this authority on the federal marshal, providing that "he shall have power to command all necessary assistance in the execution of his duty." 517 Citizen jurors authorized prosecutions as members of grand juries or applied the law as members of petit juries. ${ }^{518}$ The citizen militia could be called out to protect the community and "execute the Laws of the Union."519 Through the power to "grant Letters of Marque and Reprisal,"520 Congress could license "privateers," turning privately owned vessels into a naval force to target enemy shipping. 521 These traditional methods of involving citizens in law

5143 Blackstone, supra note 36 , at *160; see also id. at *262 (statutory forfeitures "which regard mere matters of police and public convenience" are "usually left to be inforced by common informers, in the qui tam informations or actions, of which we have formerly spoken"). The term "popular action" can be traced to Roman law. See James E. Pfander, Standing to Sue: Lessons from Scotland's Actio Popularis, 66 Duke L.J. 1493, 1500-03 \& n.41 (2017).

5153 Blackstone, supra note 36 , at $* 160$.

516 David B. Kopel, The Posse Comitatus and the Office of Sheriff: Armed Citizens Summoned to the Aid of Law Enforcement, 104 J. Crim. L. \& Criminology 761, 763-64 (2015) ("The sheriff in carrying out his peacekeeping duty may summon to his aid the able-bodied adults of the county.").

517 An Act to Establish the Judicial Courts of the United States, ch. 20, § 27, 1 Stat. 73, 87 (1789).

518 See U.S. Const. art. III, § 2; U.S. Const. amends. V-VII.

519 U.S. Const. art. I, § 8; see Jason Mazzone, The Commandeerer in Chief, 83 Notre DamE L. REv. 265, 306 (2007).

520 U.S. Const. art. I, $\$ 8$.

521 See Jenny E. Carroll, Nullification as Law, 102 GEo. L.J. 579, 587 (2014) ("The American Revolution itself was steeped in a story of the jury as a moment of direct citizen check on the oppressive power of the government."); Nicholas Parrillo, The De-Privatization of American Warfare: How the U.S. Government Used, Regulated, and Ultimately Abandoned Privateering in the Nineteenth Century, 19 Yale J.L. \& Human. 1, 8-11 (2007) (summarizing U.S. history of using privateers in military conflicts and eventual abandonment of the practice). 
enforcement and the projection of communal force often served as important safeguards against abuse of governmental powers. ${ }^{522}$ In this light, we can recognize qui tam legislation as another means of involving the public in law enforcement processes in a manner that served as a check on government officials.

\section{ConClusion}

This Article has highlighted an important aspect of our legal history and drawn out implications for constitutional interpretation. While qui tam informers can prevent abuse of governmental power, my goal has not been to advocate widespread revival of qui tam legislation targeting public officials. ${ }^{523}$ Whether or not popular actions against government officials should be a part of our legal future, their routine use in the legal past illuminates several questions about our constitutional design.

522 See John F. Romano, State Militias and the United States: Changed Responsibilities for a New Era, 56 A.F. L. Rev. 233, 236 (2005) (noting the Federalist Papers' argument that "standing armies pose a threat to liberty, and that militias will serve as a bulwark to this threat").

523 See supra note 37 and accompanying text. I have written elsewhere about the conflicts of interest that arise when we offer private financial inducements to qui tam informers for enforcing laws on behalf of the public. See Beck, supra note 108, at 608-37. 